\title{
CARACTERIZAÇÃO FISIOLÓGICA E MOLECULAR DE PLANTAS TRANSGÊNICAS DE TABACO EXPRESSANDO A LEGHEMOGLOBINA DE SOJA NO INTERIOR DOS CLOROPLASTOS
}

\section{REINALDO MONTRAZI BARATA}

Engenheiro Agrônomo

Orientador: Prof. Dr. MÁRCIO DE C. SILVA FILHO

Dissertação apresentada à Escola Superior de Agricultura "Luiz de Queiroz", Universidade de São Paulo, para obtenção do título de Mestre em Agronomia, Área de Concentração: Genética Melhoramento de Plantas.

PIRACICABA

Estado de São Paulo - Brasil Junho - 1999 
Dados Internacionais de Catalogaçāo na Publicaçāo (CIP) DIVISÃo DE BIBLIOTECA E DOCUMENTAÇĀO - Campus "Luiz de Queiroz"/USP

\author{
Barata, Reinaldo Montrazl \\ Caracterlzação fisiológica e molecular de plantas transgênlcas de tabaco \\ expressando a leghemogloblna de sola no interior dos cloroplastos / Reinaldo Montrazi \\ Barata. - - Piracicaba, 1999. \\ 116 p. : 11. \\ Dissertação (mestrado) - - Escola Superior de Agricultura Luiz de Queiroz, 1999. \\ Bibliografia.
}

1. Cloroplasto 2. Flslologla vegetal 3. Fumo 4. Melhoramento genético vegetal 5. Metabolismo vegetal 6. Planta transgênica 7. Proteina de soja I. Titulo

CDD 633.71 


\title{
CARACTERIZAÇÃO FISIOLÓGICA E MOLECULAR DE PLANTAS TRANSGÊNICAS DE TABACO EXPRESSANDO A LEGHEMOGLOBINA DE SOJA NO INTERIOR DOS CLOROPLASTOS
}

\section{Reinaldo Montrazi Barata}

Dissertação apresentada à Escola Superior de Agricultura "Luiz de Queiroz", Universidade de São Paulo, para obtençăo do título de Mestre em Agronomia, Área de Concentraçåo: Genética $\theta$ Melhoramento de Plantas.

\author{
PIRACICABA \\ Estado de São Paulo - Brasil \\ Junho - 1999
}


Aos meus pais, Renato e Suely, As minhas irmãs Renata e Carla, A minha sobrinha Mariana,

\title{
OFEREÇO
}

\begin{abstract}
A Sabrina e Nathália, responsáveis pelo estímulo e inspiração no dia-dia,
\end{abstract}

DEDICO. 


\section{AGRADECIMENTOS}

Meus agradecimentos a todas as pessoas que, direta ou indiretamente, contribuíram para a realização deste trabalho, em especial:

Ao Prof. Dr. Márcio de Castro Silva Filho pela orientação, apoio, amizade e paciência durante a realização deste trabalho;

Aos Profs. Drs. Ricardo Antunes Azevedo e Carlos Alberto Labate do Departamento de Genética da ESALQ-USP, e à Sabrina M. Chabregas pela participação e obtenção dos resultados;

Aos amigos do laboratório de Biologia Molecular de Plantas pela convivência, amizade e incentivo em todos os momentos;

À Fundação de Amparo à Pesquisa do Estado de São Paulo (FAPESP), pelo apoio financeiro;

À todos os professores, alunos e funcionários do Departamento de Genética da ESALQ-USP, em especial ao técnico Rafael Colombi pelo auxílio e amizade;

Aos funcionários do Setor de Biblioteca Central e do Departamento de Genética da ESALQ-USP, pelos auxílios prestados. 


\section{SUMÁRIO}

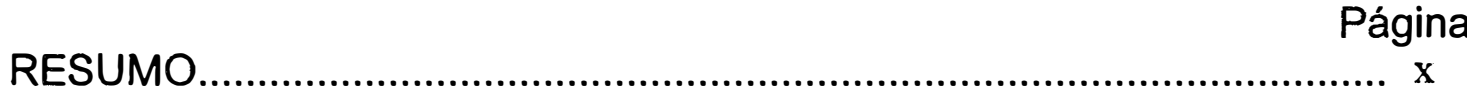

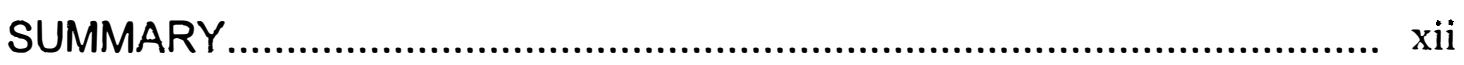

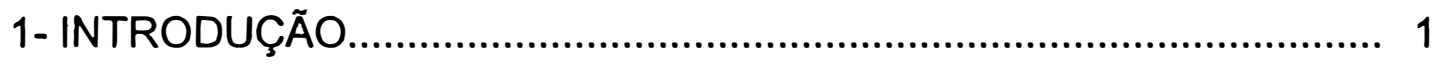

2- REVISÃO DE LITERATURA......................................................... 3

2.1- Fotossintese ............................................................................. 3

2.1.1- Fase dependente de luz...................................................... 3

2.1.2- Fase independente de luz..................................................... 4

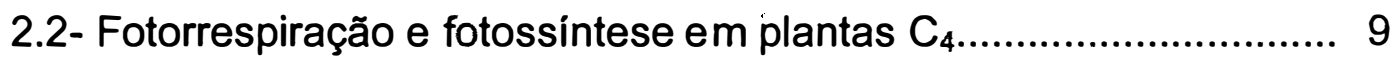

2.3- Sintese de sacarose e de amido...................................................... 14

2.4- Estresse oxidativo................................................................. 17

2.4.1- Superóxido dismutase (SOD) ................................................. 19

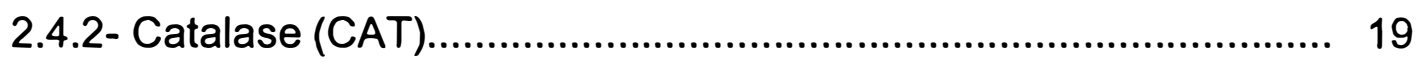

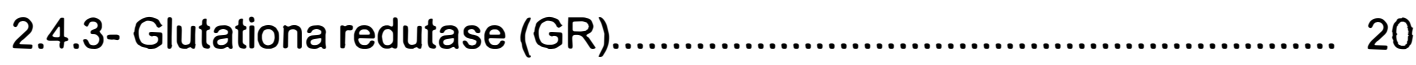

2.5- Hemoglobinas de plantas........................................................ 21

2.6- Direcionamento de proteínas aos cloroplastos.............................. 24

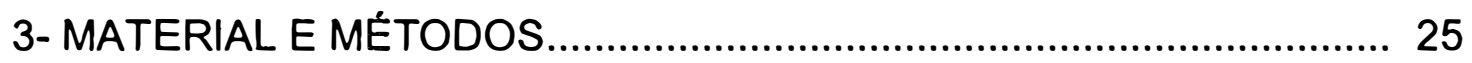

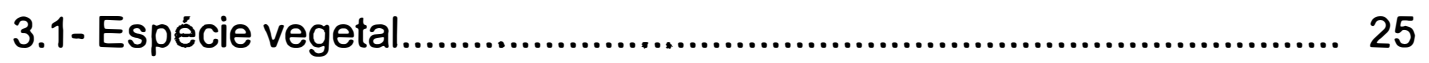

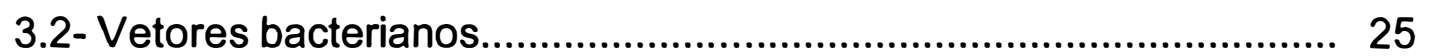

3.3- Cepa bacteriana......................................................................... 27

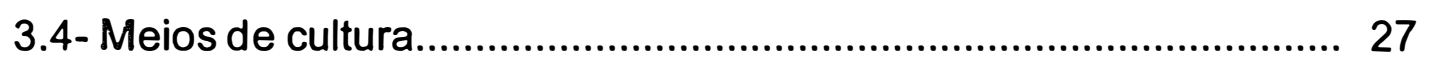

3.5- Transformação de plantas.......................................................... 27

3.6- Extração de DNA das plantas...................................................... 28

3.7- Verificação da presença do T-DNA nas plantas............................ 28

3.8- Extração de proteinas totais......................................................... 29 
3.9- Análise da concentração de proteínas.......................................... 29

3.10- Eletroforese e imunodeteç̧ão..................................................... 30

3.10.1- Solubilização de proteínas e eletroforese................................. 30

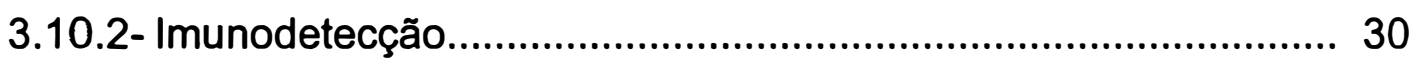

3.11- Preparo do extrato foliar para determinação de sacarose e

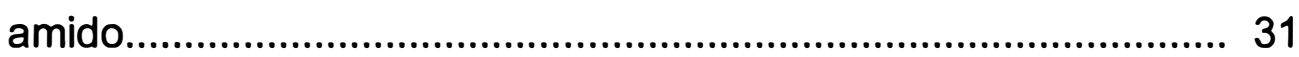

3.11.1 - Determinação de feofitina.................................................. 31

3.11.2- Determinação do conteúdo de sacarose e amido...................... 32

3.11.2.1- Determinação do conteúdo de sacarose............................... 32

3.11.2.2- Determinação do conteúdo de amido...................................... 33

3.12- Determinação do conteúdo de clorofila a e b................................ 34

3.13- Isolamento de cloroplastos.......................................................... 35

3.14- Extração das enzimas envolvidas no estresse oxidativo............... 36

3.15- Determinação das atividades totais da catalase (CAT), glutationa redutase (GR) e superóxido dismutase (SOD)............. 36

3.15.1- Gel de atividade para SOD................................................... 37

3.16- Determinação de peso seco........................................................ 38

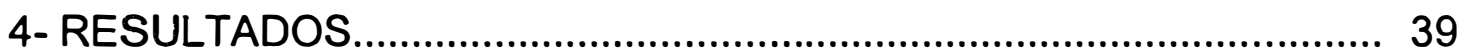

4.1- Obtenção das plantas transgênicas............................................. 39

4.2- Análise das plantas transgênicas................................................ 39

4.2.1 - Screening por PCR e Western Blotting....................................... 39

4.2.2- O peptídeo de trânsito da Rubisco direciona a leghemoglobina ao interior dos cloroplastos....................................................... 42

4.2.3- Determinação do conteúdo de clorofila $a$ e $b$ das plantas

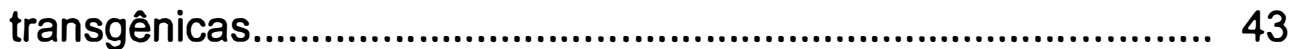

4.2.4- Análise de peso seco nas plantas transgênicas......................... 45

4.2.5- Análise do teor de sacarose e amido....................................... 50

4.2.6- Análise da atividade da catalase, glutationa redutase e superóxido dismutase. 


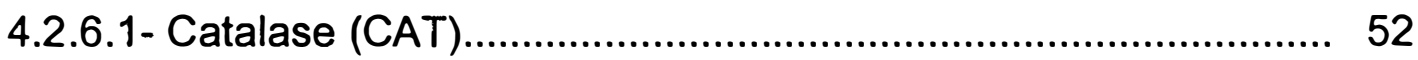

4.2.6.2- Glutationa redutase (GR) .................................................. 54

4.2.6.3- Superóxido dismutase (SOD) ............................................... 55

4.2.7- Fotossintese...................................................................... 58

5- DISCUSSÃO

6- CONCLUSÃO

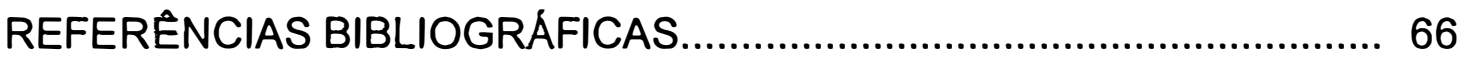

ANEXO 


\section{LISTA DE ABREVIATURAS}

$A D P=$ adenosina di-fosfato

AGPase $=$ ADP-glucose pirofosforilase

APX = ascorbato peroxidase

ATP $=$ a denosina tri-fosfato

$\mathrm{BSA}=$ soro albumina bovina

CA1-P = 2-carboxiarabinitol-1-fosfato

$\mathrm{CAT}=$ catalase

DTT $=$ ditriotheitol

EDTA = etilenodiaminatetra acetato dissódico

$\mathrm{Fd}=$ ferredoxina

G6-P = glicose 6-fosfato

G6-Pdh = glicose 6-fosfato desidrogenase

$\mathrm{GR}=$ glutationa redutase

GS/GOGAT = glutationa sintetase/ glutamato sintase

HEPES = ácido N (2-hidroxietil) piperazine N (2-etanosulfônico)

$\mathrm{kDa}=$ kilo Dalton

$\mathrm{Km}=$ constante de Michaellis

$\mathrm{Lb}^{+2}=$ leghemoglobina no estado ferroso

$\mathrm{Lb}^{+3}=$ leghemoglobina no estado férrico

Iba = gene da leghemoglobina de soja

Lba = leghemoglobina de soja

MÊS = ácido 2[N-morfolino]etano-sulfônico

$\mathrm{NADH}=$ nicotinamida adenina binucleotídeo, forma reduzida

$\mathrm{NAD}(\mathrm{P}) \mathrm{H}=$ nicotinamida adenina binucleotídeo (fosfato), forma reduzida

$\mathrm{pb}=$ pares de bases

PBS = tampão fosfato salino

$\mathrm{PCR}$ = reação da polimerase em cadeia

$\mathrm{PEP}$-carboxilase $=$ fosfoenol piruvato-carboxilase 
3-PGA = ácido 3-fosfoglicérico

$P_{i}=$ fosfato inorgânico

ppm = partes por milhão

$\mathrm{PSI}=$ fotossistema $\mathrm{I}$

$(p / v)=$ peso/volume

$\mathrm{PVP}=$ polivinil pirrolidone

rbcL = subunidade maior da Rubisco

rbcS = subunidade menor da Rubisco

ROS = espécies reativas de oxigênio

$\mathrm{rpm}=$ rotações por minuto

RuBP = ribulose 1,5 bisfosfato

Rubisco = ribulose 1,5 bisfosfato carboxilase/oxigenase

SDS $=$ sódio dodecil sulfato

SOD = superóxido dismutase

TBS = tampão Tris salino

$T-D N A=$ DNA de transferência

Tris $=$ tris(hidroximetil)aminometano

Tween = polioxietilenosorbitol

UDP = uridina difosfato 


\title{
CARACTERIZAÇÃO FISIOLÓGICA E MOLECULAR DE PLANTAS DE TABACO EXPRESSANDO A LEGHEMOGLOBINA DE SOJA NO INTERIOR DOS CLOROPLASTOS
}

\author{
Autor: REINALDO MONTRAZI BARATA \\ Orientador: Prof. Dr. MÁRCIO DE C. SILVA FILHO
}

\section{RESUMO}

O oxigênio é essencial no processo respiratório e participa tanto no metabolismo primário quanto no secundário das células vegetais. Várias tentativas têm sido feitas no sentido de interferir no metabolismo aeróbico das plantas, especialmente no que se refere às reações de oxigenação ou carboxilação da Rubisco. O desenvolvimento de uma proteina Rubisco (ribulose 1,5-bisfosfato carboxilase/oxigenase) mais eficiente é problemático, pois sua manipulação estrutural conduz frequentemente a um aumento da atividade oxigenase, que é responsável direta pelas perdas geradas durante o processo fotorrespiratório.

A fim de reduzir a disponibilidade de oxigênio no interior dos cloroplastos foi construido um gene quimérico formado pelo cDNA da leghemoglobina de soja ( $/ \mathrm{ba}$ ) ligado ao fragmento de DNA que codifica a sequência de direcionamento aos cloroplastos da pequena subunidade da Rubisco de ervilha. Esta construção foi introduzida em Nicotiana tabacum via transformação genética utilizando Agrobacterium tumefaciens.

A análise das plantas transgênicas revelou que a leghemoglobina foi eficientemente importada e corretamente processada no interior dos cloroplastos de tabaco. Além disso, o nível máximo de expressão da Lba no tecido foliar variou de 0,01 a $0,1 \%$. 
A análise fotossintética, produção de metabólitos (amido e sacarose) e enzimas envolvidas no metabolismo aeróbico das células (catalase [CAT], glutationa redutase [GR] e superóxido dismutase [SOD]) revelaram que, apesar da alta afinidade da leghemoglobina ao oxigênio, nenhuma diferença significativa foi observada quando comparada com as das plantas controle. Esses resultados sugerem que uma concentração muito elevada de leghemoglobina precisa estar presente no interior da organela para que ela possa agir transportando ou facilitando a difusão do oxigênio. 


\title{
PHYSIOLOGICAL AND MOLECULAR CHARACTERIZATION OF TOBACCO TRANSGENIC PLANTS EXPRESSING SOYBEAN LEGHEMOGLOBIN INSIDE CHLOROPLASTS
}

\author{
Author: REINALDO MONTRAZI BARATA \\ Adviser: Prof. Dr. MÁRCIO DE C. SILVA FILHO
}

\section{SUMMARY}

Oxygen is essential for respiration and also participates in the primary and secondary metabolism of plant cells. Several attempts have been made to alter the aerobic metabolism in plants, especially those related to the oxygenation or carboxylation of Rubisco (ribulose 1,5-bisphosphate carboxylase-oxygenase). However, designing a more effective Rubisco protein is rather problematic since its structural manipulation leads frequently to an enhancement of oxygenase activity, which is responsible for photorespiratory losses.

In order to reduce oxygen availability inside chloroplasts a chimeric gene, consisting of a soybean leghemoglobin cDNA ( $\mathrm{Iba}$ ) bound to the chloroplast targeting signal sequence of the Rubisco small subunit gene was introduced and expressed in Nicotiana tabacum.

Leghemoglobin was efficiently imported and correctly processed inside the chloroplasts in transgenic tobacco plants. Furthermore, the maximum level of Lba expression in leaf tissue ranged from 0,01 a $0,1 \%$.

Analysis of photosynthesis, metabolite production (sucrose and starch) and enzymes involved in aerobic metabolism in plants cells (catalase [CAT], glutathione reductase [GR] and superoxide dismutase [SOD]) revealed that despite of high affinity of leghemoglobin to oxygen, no difference was 
observed in relation to control plants. These results suggest that higher Lba concentrations must be present inside the organelle in order to act as an oxygen carrier or facilitate diffusion. 


\section{1- INTRODUÇÃO}

A baixa eficiência fotossintética observada nas plantas $C_{3}$ tem despertado $\circ$ interesse de vários grupos de pesquisa no mundo. Inúmeras tentativas têm sido empregadas no sentido de tornar estas plantas mais produtivas, interferindo principalmente, na redução da atividade fotorrespiratória.

Com o desenvolvimento das técnicas de engenharia genética, torna-se possivel a transferência de genes entre espécies incompativeis sob o ponto de vista reprodutivo. Além disso, permite-se a introdução de proteínas em compartimentos subcelulares possibilitando a alteração de processos metabólicos.

A proposta de pesquisa desse projeto foi expressar a leghemoglobina de soja no interior de cloroplastos de plantas de fumo (Nicotiana tabacum), visando alterar o ambiente na proximidade do sítio catalítico da enzima ribulose 1,5-bisfosfato carboxilase-oxigenase (Rubisco), devido a redução da pressão do oxigênio no interior da organela.

$O$ projeto iniciou-se com a transformação de plantas de fumo com o gene quimérico rbcS-lba. Esse gene foi obtido a partir da fusão do gene da leghemoglobina ( $/ \mathrm{ba}$ ) de soja ao fragmento de DNA que codifica a seqüência de direcionamento da subunidade menor da Rubisco ( $r b c S$ ) de evilha. A expressão do gene quimérico foi assegurada pela presença do promotor constitutivo $35 \mathrm{~S}$ do vírus do mosaico da couve-flor. 
O interesse em se estudar a expressão da leghemoglobina em cloroplastos de plantas de fumo pode ser avaliado sob vários aspectos. Primeiro, por tratar-se de uma planta $\mathrm{C}_{3}$, ele oferece condições ideais ao estudo da fotossintese e fotorrespiração, sendo um excelente modelo biológico. Segundo, Nicotiana tabacum pode ser facilmente transformada por Agrobacterium tumefaciens, tendo uma boa capacidade de regeneração de plantas transgênicas. Além disso, visto que a leghemoglobina será dirigida aos cloroplastos via uma seqüência de direcionamento, encontram-se nesta organela vários mecanismos capazes de reduzir a proteina ao seu estado funcional (Bekana \& Klukas, 1990). Entretanto, apesar de ser corretamente importada e processada no interior da organela, a leghemoglobina não interferiu no metabolismo primário das plantas transgênicas, notadamente, nos processos enzimáticos da fotossintese. Os resultados permitem supor que a ausência de efeitos sobre a fisiologia das plantas deva-se às concentrações observadas da proteina no interior da organela de modo a interferir no transporte de oxigênio. 


\section{2- REVISÃO DE LITERATURA}

\section{1- Fotossíntese}

A fotossintese é um dos processos fisiológicos mais importantes dos seres vivos. Basicamente, ela consiste na produção de carboidratos a partir de $\mathrm{CO}_{2}$, água e energia luminosa. Nos vegetais mais desenvolvidos, o órgão sede da fotossintese é a folha. Nela, encontram-se as células verdes dotadas de clorofila, responsáveis pelo processo fotossintetizante. Essas células constituem o chamado parênquima clorofiliano em cujo interior encontram-se os cloroplastos, que são as organelas citoplasmáticas onde $\circ$ processo fotossintético se desenvolve (Lea \& Leegood, 1995).

Embora o mecanismo fotossintetizante ainda não esteja completamente esclarecido, sabe-se que a fotossintese envolve duas etapas: a fotoquímica (fase dependente de luz) e a química (fase independente de luz).

\subsection{1- Fase dependente de luz}

A fase dependente de luz ou fotoquímica da fotossintese é um evento que ocorre na membrana tilacóide dos cloroplastos (Anderson \& Styring, 1991) e consiste na conversão de energia solar em energia química representada pelo poder redutor e energético presentes nas moléculas de NADPH e ATP produzidos. Estas membranas contém pigmentos e uma complexa estrutura envolvida na captura de luz dispostas de maneira otimizada 
a fim de proporcionar máxima eficiência para absorção da energia luminosa (Anderson \& Styring, 1991).

Os produtos formados (ATP e NADPH), conhecidos como força assimilatória (Dietz \& Huber, 1986), serão usados posteriormente nas reações independentes de luz para fixação de $\mathrm{CO}_{2}$.

\subsection{2- Fase independente de luz}

As plantas verdes apresentam em seus cloroplastos um complexo enzimático capaz de catalisar a conversão de $\mathrm{CO}_{2}$ em compostos orgânicos. Este processo de fixação do carbono foi elucidado na década de 50 por Melvịn Calvin e Andrew Benson (Lea \& Leegood, 1995).

Segundo Furbank \& Taylor (1995), a maior parte das plantas cultivadas, incluindo feijão, soja, trigo, batata e fumo utilizam o metabolismo $C_{3}$ de fotossintese, também chamado de Ciclo de Redução Fotossintética, onde o primeiro passo na fixação de carbono é a reação do $\mathrm{CO}_{2}$ com a ribulose-1,5bifosfato (RuBP) para formar duas moléculas de três carbonos, o 3fosfoglicerato. O Ciclo de Calvin-Benson pode, para efeito didático, ser dividido em três estágios que serão detalhados a seguir (Figura 1).

A primeira etapa consiste na carboxilação da ribulose 1,5bisfosfato (RuBP); catalisada pela enzima ribulose-1,5-bisfosfato carboxilase/oxigenase (Rubisco) que está localizada no estroma cloroplástico.

A Rubisco está presente nas plantas superiores como um grande complexo macromolecular de cerca de $550 \mathrm{kDa}$, que consiste de 8 subunidades grandes de $56 \mathrm{kDa}$ cada, aproximadamente, e 8 subunidades pequenas de 14 kDa cada (Knight et al., 1990). As subunidades maiores são codificadas por um único gene cloroplastidial, o $r b c L$, enquanto que as 8 subunidades pequenas são codificadas por uma pequena família de genes nucleares denominados genes rbcS (Broglie et al., 1983; Dean et al., 1985). Esta enzima está sujeita à 


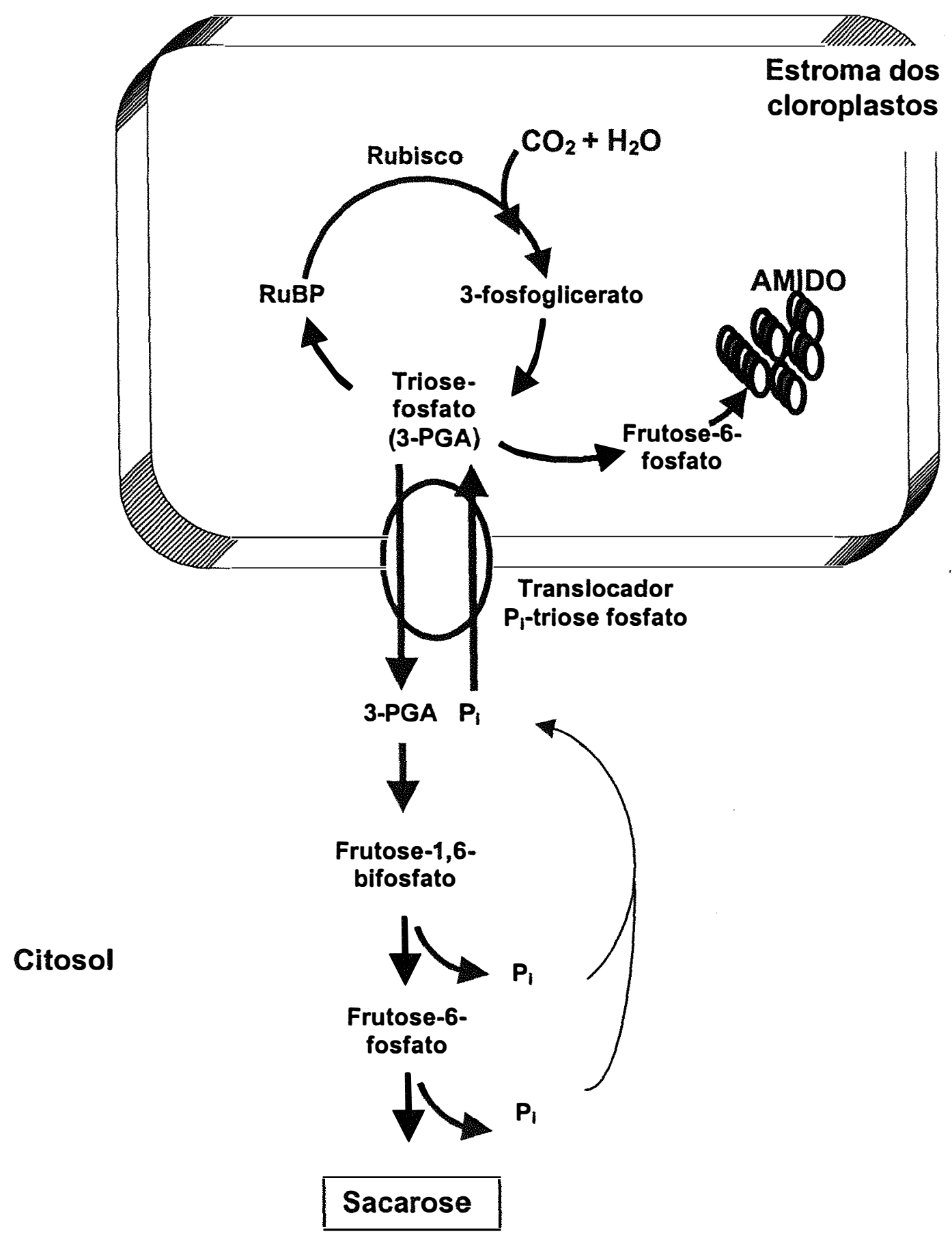

Figura 1: Esquema simplificado do Ciclo de Calvin-Benson e da síntese de sacarose e amido. 
regulação pela adição covalente de uma molécula de $\mathrm{CO}_{2}$ ao grupo $\varepsilon$-amino de um determinado resíduo de lisina (Lys-201 em espinafre) para formar um grupo carbamato (Lorimer \& Miziokko, 1980; Lorimer, 1981; Gutteridge \& Gatemby, 1995). Este carbamato liga-se ao ion $\mathrm{Mg}^{+2}$ e o complexo resultante é essencial para a atividade enzimática

Segundo Pierce (1988), a Rubisco apresenta $\mathrm{Km}$ ao $\mathrm{CO}_{2}$ elevado $\left(\mathrm{Km}_{\mathrm{CO} 2}=25 \mu \mathrm{M}\right.$ em condições normais $) \mathrm{e}$, consequentemente, baixa afinidade por $\mathrm{CO}_{2}$. Por isso, como relatado por Evans (1989), as plantas $\mathrm{C}_{3}$ empregam até $50 \%$ das suas proteinas solúveis para manter esta enzima. A Rubisco pode ligar-se também a uma molécula de oxigênio no mesmo sítio ativo. Esta atividade oxigenase leva à oxigenação da RuBP e à degradação oxidativa do produto formado (Hartman \& Harpel, 1994). Desta forma, dois processos competitivos estão relacionados à atividade da Rubisco: a fotossintese (atividade carboxilase) e a fotorrespiração (atividade oxigenase).

Por ser o local onde se inicia a fixação fotossintética do $\mathrm{CO}_{2}$, a enzima Rubisco é o primeiro alvo dos mecanismos de regulação da fotossintese (Hartman \& Harpel, 1994). Um tipo de regulação envolve a carbamilação de um resíduo de lisina, fator essencial para torná-la cataliticamente competente (Andrews \& Lorimer, 1987). Em niveis altos de $\mathrm{CO}_{2}$ isto ocorre de forma não-enzimática. Entretanto, o substrato para esta enzima, RuBP, inibe a carbamilação e este efeito é quase completo em concentrações fisiológicas de $\mathrm{CO}_{2}$ (Jordan \& Chollet, 1983). Úma enzima chamada Rubisco ativase supera esta inibição e promove a carbamilação da Rubisco de uma forma dependente de ATP (Somerville et al., 1982; Salvucci et al., 1985). O mecanismo de ativação é desconhecido e não está claro porque o ATP é necessário (Mate et al.,1996).

A Rubisco também é inibida por um componente de ocorrência natural, o 2-carboxiarabinitol-1-fosfato (CA1-P), que apresenta uma estrutura similar a do intermediário $\beta$-cetoácido da reação da Rubisco (Kobza \& Seemann, 1988). Este composto é sintetizado no escuro por algumas plantas 
para reprimir a atividade da Rubisco e algumas vezes é chamado de "inibidor noturno" (Berry et al., 1987). Quando a luz retorna, ele é degradado, permitindo a reativação da atividade da enzima. Foyer (1986) sugere que CA1-P seja o inibidor mais abundante do mundo.

Portanto, a taxa de assimilação de $\mathrm{CO}_{2}$ que ocorre na folha depende da quantidade e da atividade da Rubisco presente, da concentração de seus substratos, RuBP e $\mathrm{CO}_{2}$, da concentração de $\mathrm{O}_{2}$, que é o inibidor competitivo, do $\mathrm{pH}$ estromal, e da temperatura da folha. $\mathrm{O}$ nivel de $\mathrm{CO}_{2}$ no estroma é regulado pela taxa de difusão do fosfato inorgânico (Pi) no cloroplasto e a disponibilidade de RuBP (Hudson et al., 1992).

O segundo e o terceiro estágios do Ciclo de Calvin-Benson referem-se à conversão do 3-fosfoglicerato em gliceraldeído-3-fosfato (triose fosfato) e a regeneração da RuBP, respectivamente. Esses dois estágios necessitam de uma série de enzimas e consomem força assimilatória (ATP e NADPH) produzida na fase fotoquímica da fotossintese (Geiger \& Servaites, 1994).

O Ciclo de Calvin-Benson permanece na interface entre o transporte de elétrons e a sintese de produtos da fotossintese, sendo sensivel a variações das condições ambientais que causem alterações nas relações entre suprimento e demanda dos produtos do transporte de elétrons (Leegood, 1985). Segundo o mesmo autor, a atividade das enzimas do ciclo é controlada de várias formas: 1) a ativação pela luz e modulação por metabólitos permitem um ajuste rápido da atividade dessas enzimas, enquanto que 2) a síntese de proteinas permite que a quantidade dessas enzimas apresente uma regulação a longo prazo. Por exemplo, a fixação redutiva do $\mathrm{CO}_{2}$, como visto anteriormente, necessita de ATP e NADPH e suas concentrações no estroma aumentam quando os cloroplastos são iluminados. O transporte de prótons induzidos pela luz através da membrana tilacóide também transforma o compartimento estromal em alcalino e é acompanhado pelo fluxo de $\mathrm{Mg}^{+2}$ para fora do compartimento tilacóide em direção ao estroma. Várias enzimas do 
estroma evoluíram para tomar vantagem dessas condições de luz que sinalizam a disponibilidade de ATP e NADPH. Elas têm $\mathrm{pH}$ ou concentrações de $\mathrm{Mg}^{+2}$ ótimos que são melhor adaptados para as condições alcalinas e alta concentração de $\mathrm{Mg}^{+2}$. A ativação da Rubisco pela formação de carbamato de lisina é mais rápida em pH alcalino, sendo que altas concentrações de $\mathrm{Mg}^{+2}$ no estroma favorecem a formação do complexo ativo com este cátion (Geiger e Servaites, 1994).

Três outras enzimas essenciais para a operação do Ciclo de Calvin-Benson estão submetidas a outro tipo de regulação pela luz. As enzimas ribulose-5-fosfato quinase, frutose-1,6-bifosfatase e sedoeptulose-1,7bifosfatase, podem existir em duas formas alternativas que diferem entre si apenas no estado de oxidação de um resíduo de cisteína essencial para sua atividade catalítica. Quando esses resíduos de cisteína são oxidados como pontes dissulfetos, as enzimas tornam-se inativas. Esta é a situação normal no escuro. Com a iluminação, os elétrons fluem do fotossistema I para a ferredoxina, que passa os elétrons para uma proteína solúvel e de baixo peso molecular que contém grupos dissulfeto chamada tiorredoxina. A tiorredoxina fornece os seus elétrons para a redução das pontes dissulfeto dessas enzimas ativadas pela luz e, a seguir, é reativada em uma reação de troca de dissulfetos catalisada pela tiorredoxina redutase (Buchanan, 1991; Furbank \& Taylor, 1995).

Assim, o conhecimento da regulação da Rubisco e das outras enzimas do Ciclo de Calvin-Benson é importante para entender a regulação coordenada entre a utilização de RuBP na carboxilação, absorção de luz e uso de energia para regeneração de RuBP, que são os passos fundamentais para o processo fotossintético (Salvucci, 1989; Portis, 1990, 1992; Hudson et al, 1992). 


\section{2- Fotorrespiração e fotossíntese em plantas $C_{4}$}

A especificidade da Rubisco para $\circ \mathrm{CO}_{2}$ como substrato não é absoluta. $\mathrm{O} \mathrm{O}_{2}$ compete com o $\mathrm{CO}_{2}$ pelo mesmo sítio ativo. A Rubisco catalisa a condensação de $\mathrm{O}_{2}$ com RuBP, para formar uma molécula de 3-fosfoglicerato e uma de 2-fosfoglicolato (Figura 2) que se configura como o substrato para a fotorrespiração (Bowes et al., 1971; Laing et al.,1974; Badger et al.,1984). A função metabólica desta reação não é clara. Ela não resulta em qualquer fixação de carbono e parece representar um prejuizo final para a célula na qual ocorre, pois o fosfoglicolato não é um metabólito útil e recuperar os seus carbonos consome energia celular (Zelitch, 1992). Segundo o mesmo autor, a fotorrespiração é um processo que não conserva energia.

Em condições atmosféricas normais, a fotorrespiração ocorre em proporções bastante significativas constituindo-se num dos mecanismos mais importantes de desperdício de energia que se tem conhecimento. Estima-se que a fixação do oxigênio (fotorrespiração) seja responsável por uma inibição da síntese de biomassa da ordem de 50\% (Chollet, 1975; Zelitch, 1992).

Cerca de $90 \%$ do peso seco das plantas é derivado da assimilação de $\mathrm{CO}_{2}$ catalisada pela Rubisco. Então, aumentar a taxa fotossintética pode ser benéfica para a produtividade das plantas (Zelitch, 1982). Alguns autores (Heber et al., 1990) argumentam que a diminuição do processo fotorrespiratório resulta no dano fotoxidativo das membranas do aparato fotossintético. Contudo, Zelitch (1992) relata que esta conclusão é errônea pois baseia-se em extrapolações de experimentos com cloroplastos isolados e concentrações de $\mathrm{CO}_{2}$ muito abaixo daquelas encontradas no interior das folhas in natura. No mesmo artigo, o autor demonstra que a regulação da fotorrespiração é acompanhada por efeitos benéficos na fotossíntese líquida.

Assim, várias tentativas têm sido feitas no sentido de inibir a fotorrespiração nas plantas $C_{3}$, a fim de aumentar a eficiência na fixação de 


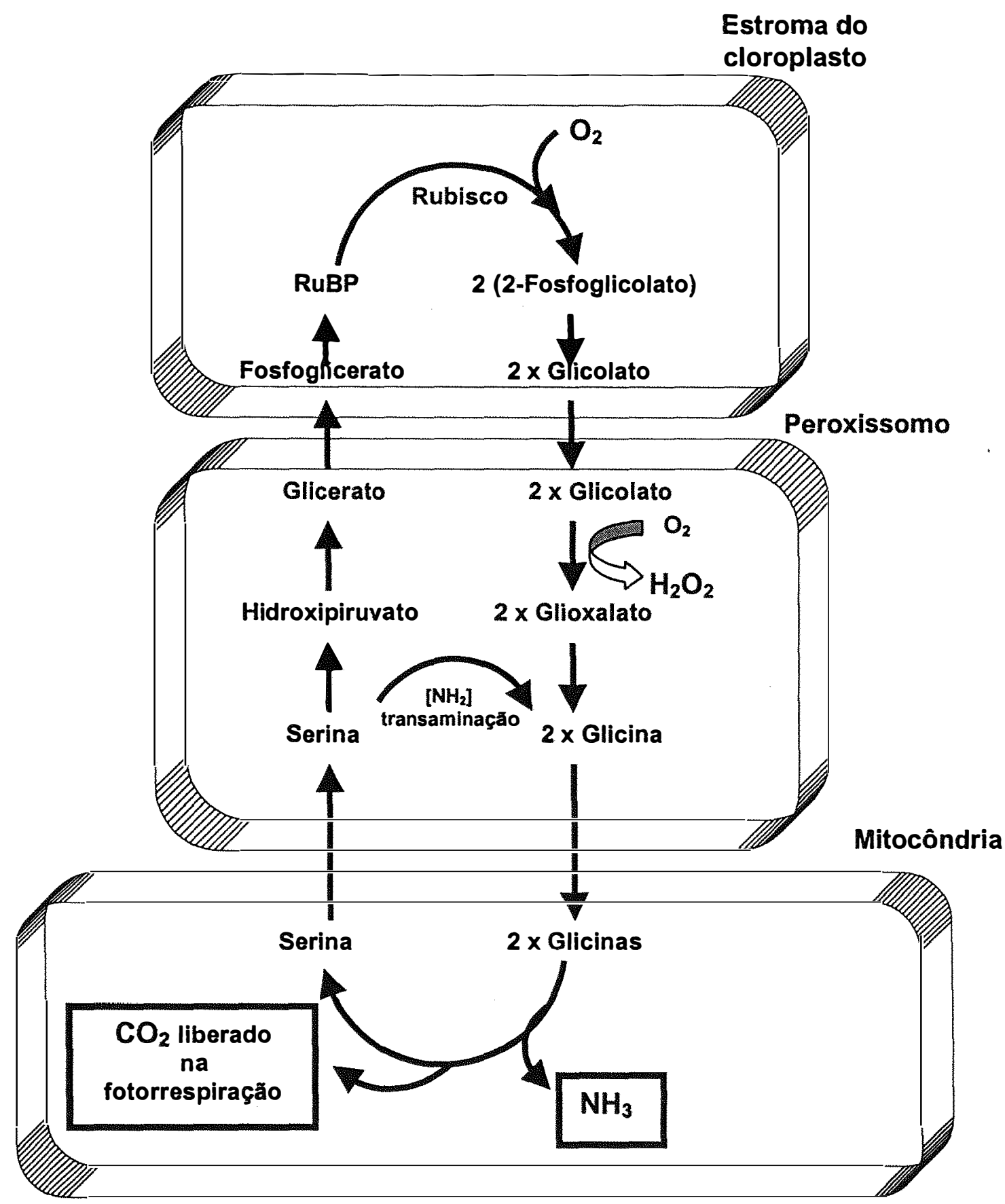

Figura 2: Esquema simplificado do processo fotorrespiratório. (Adaptado de Lehninger et al., 1993). 
$\mathrm{CO}_{2} \mathrm{e}$, portanto, produção de biomassa. Uma abordagem seria a de alterar a conformação da Rubisco, favorecendo sua atividade carboxilase (Zhu \& Spreitzer, 1996). Entretanto, os esforços para conseguir uma enzima mais eficiente na fixação de $\mathrm{CO}_{2}$ não têm logrado sucesso (Spreitzer, 1993). Por outro lado, a diminuição da concentração de $\mathrm{O}_{2}$ ou o aumento na de $\mathrm{CO}_{2}$, leva a um aumento da atividade fotossintética das plantas $C_{3}$ (Stitt, 1991). Dimah et al. (1995) verificaram um aumento na capacidade fotossintética em plantas de trigo cultivadas em altas concentrações de $\mathrm{CO}_{2}$. Segundo os autores, o aumento da capacidade de fixação de carbono deveu-se ao aumento da atividade carboxilase da Rubisco, decréscimo da atividade fotorrespiratória e ao aumento do transporte de elétrons nos tilacóides, e consequentemente, aumento da produção de ATP, NADPH e RuBP. Recentemente, Brisson et al. (1998) manipulando os níveis de catalase em plantas de tabaco, conseguiram aumentar a fotossíntese líquida. $O$ aumento do nivel de catalase nas plantas transgênicas evitou a descarboxilação de cetoácidos tais como hidroxipiruvato e glioxilato causado pelo excesso de peróxido de hidrogênio $\left(\mathrm{H}_{2} \mathrm{O}_{2}\right)$.

Esses resultados demonstram que uma alternativa para contornar a dificuldade em alterar a estrutura molecular da proteina é modificar o ambiente de reação. Basicamente, esta foi a estratégia desenvolvida no decorrer do processo evolutivo pelas plantas $\mathrm{C}_{4}$. Essas plantas, típicas de regiões onde há alta luminosidade e temperatura (regiões tropicais), conseguem maior taxa de fotossintese mesmo em pequenas concentrações de $\mathrm{CO}_{2}$, pois apresentam em suas folhas uma característica anatômica que representa importante parâmetro na diferenciação das plantas $\mathrm{C}_{4}$ das plantas $\mathrm{C}_{3}$ (Hatch, 1988). Elas têm nas células do parênquima clorofiliano do mesófilo foliar, cloroplastos que efetuam a etapa $\mathrm{C}_{4}$ de fixação do carbono. Há ainda, células clorofiladas especiais que envolvem os feixes condutores (células da bainha vascular), em cujos cloroplastos ocorre a seqüência do processo, isto é, a etapa $\mathrm{C}_{3}$ (Hatch, 1988). 
Em termos bioquímicos, na fixação $\mathrm{C}_{4}, \circ \mathrm{CO}_{2}$ reage inicialmente com uma substância, o PEP (fosfoenolpiruvato), formando o oxaloacetato que em seguida é convertido em malato ou aspartato. O malato ou o aspartato são transportados para os cloroplastos das células da bainha vascular e cedem $\mathrm{CO}_{2}$ para iniciar o ciclo de Calvin (Figura 3). Assim, um dos parâmetros mais importantes na distinção das plantas $\mathrm{C}_{4}$ das $\mathrm{C}_{3}$ refere-se à capacidade dos tecidos das espécies $\mathrm{C}_{4}$ de concentrarem $\circ \mathrm{CO}_{2}$ atmosférico nos sítios de produção de carboidratos, ou seja, nas células da bainha vascular (Chollet, 1975).

Sabe-se que ambas as plantas $\left(\mathrm{C}_{4}\right.$ e $\left.\mathrm{C}_{3}\right)$ apresentam o processo de fotorrespiração ativo, se bem que com intensidades diferentes, mas as primeiras têm a capacidade de capturar o $\mathrm{CO}_{2}$ no seu caminho em direção à atmosfera, pela reação da PEP-carboxilase, que mostra grande afinidade pelo gás carbônico (Ogren, 1984). Desta maneira, as plantas $\mathrm{C}_{4}$ não perdem $\mathrm{CO}_{2}$ para a atmosfera e o sistema de descarboxilação do malato ou oxalacetato, que ocorre na bainha vascular, contribui para o aumento da quantidade de gás carbônico disponivel no sítio ativo da enzima Rubisco, que funciona em concentrações de $60 \mu \mathrm{M}$ de $\mathrm{CO}_{2}$, ou mais (Hatch, 1976). Nestas condições, a Rubisco apresenta máximas velocidade de reação, pois encontram-se em saturação de substrato, considerando um $\mathrm{K}_{\mathrm{m}}$ de $20 \mu \mathrm{M}$ (Hatch, 1976). A característica anatômica das plantas $\mathrm{C}_{4}$ representada pela síndrome de Kranz propicia que os produtos da assimilação do carbono, principalmente os carboidratos, aminoácidos e ácidos orgânicos, sejam facilmente transferidos para o sistema vascular (floema) e translocados para outras partes da plantas com menor gasto de energia metabólica (Furbank \& Taylor, 1995).

Outra importante caracteristica fisiológica que distingue as plantas $\mathrm{C}_{3}$ das $\mathrm{C}_{4}$ refere-se à eficiência de utilização do nitrogênio nos processos de assimilação. Black e colaboradores (1977) demonstraram que as plantas $C_{4}$, 


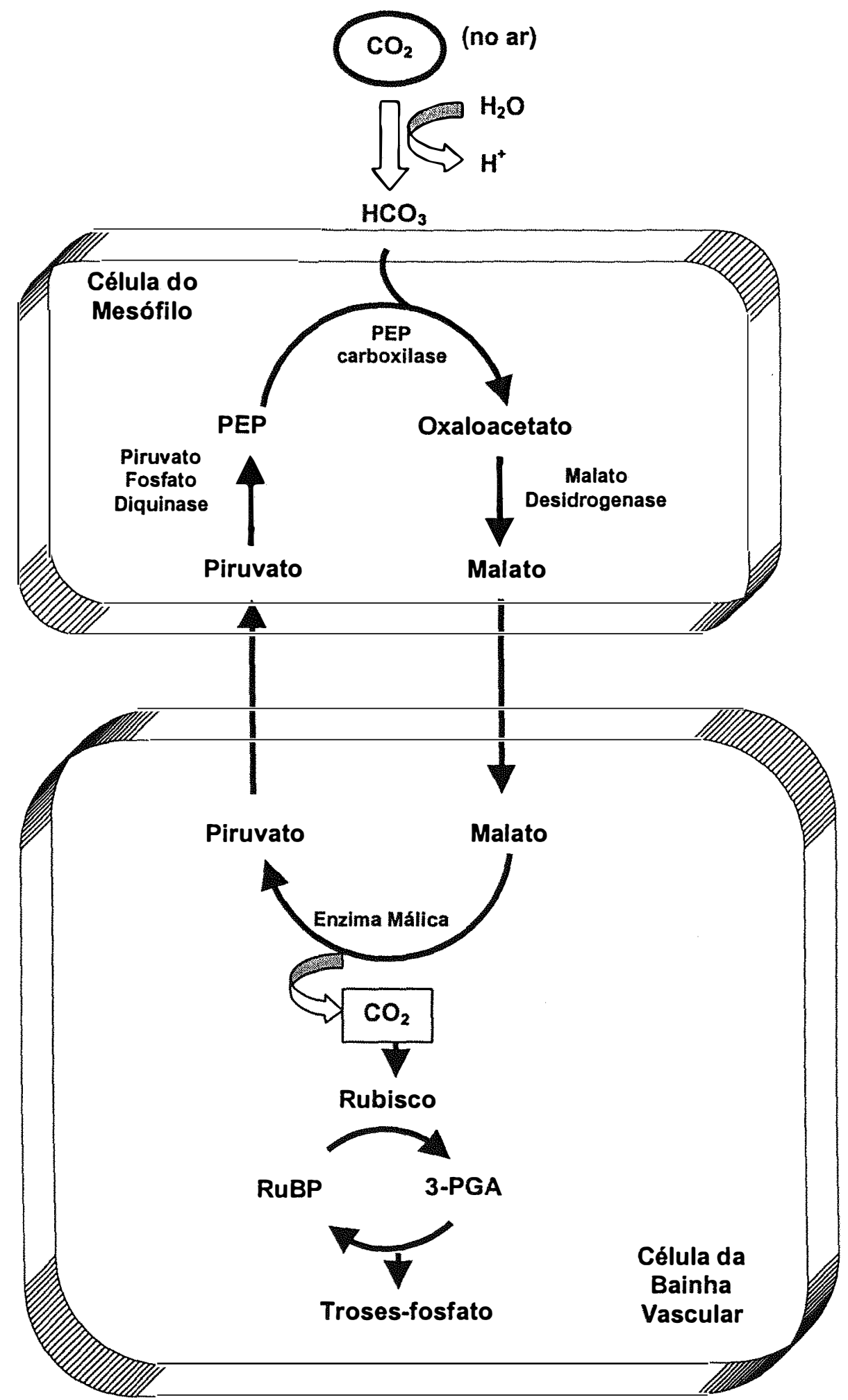

Figura 3: Esquema simplificado da via de Hatch-Slack que promove a fixação do $\mathrm{CO}_{2}$ através de um intermediário de quatro átomos de carbono. Esta via prevalece nos vegetais de origem tropical (vegetais tipo $\mathrm{C}_{4}$ ). Esquema reproduzido de Lehninger et al., 1993. 
em comparação com as plantas $C_{3}$, produzem duas vezes mais matéria seca por unidade de nitrogênio presente nas folhas, devido ao fato da fotossintese apresentar valores duas vezes mais altos com a mesma quantidade de nitrogênio. A localização da Rubisco quase que exclusivamente nas células da bainha vascular, faz com que as espécies $\mathrm{C}_{4}$ utilizem de 5 a $10 \%$ da proteina solúvel das folhas na forma desta enzima, enquanto as plantas $\mathrm{C}_{3}$ investem de $40-50 \%$ no mesmo processo, o que indica ser uma compensação para a sua baixa eficiência (Hatch, 1988).

Como decorrência da eficiência de fixação de $\mathrm{CO}_{2}$ que é feita pelas espécies $\mathrm{C}_{4}$ que 0 perdem em quantidades mínimas no processo fotorrespiratório, essas plantas apresentam ponto de compensação ao redor de 5-10ppm de $\mathrm{CO}_{2}$, enquanto as $\mathrm{C}_{3}$ mostram ponto de compensação de 50$150 \mathrm{ppm}$ de $\mathrm{CO}_{2}$. Em função das respostas das várias espécies com relação à concentração do gás carbônico da atmosfera, as plantas $C_{4}$ têm maior capacidade de enfrentar a competição que se estabelece em comunidades vegetais muito densas, nas quais poderá ocorrer limitação do $\mathrm{CO}_{2}$ para a fotossintese (Lea \& Leegood, 1995).

Todas estas observações demonstram a necessidade de se desenvolver estratégias visando a diminuição da atividade fotorrespiratória e conseqüente aumento da atividade de carboxilase da Rubisco em plantas $\mathrm{C}_{3}$.

\section{3- Síntese de Sacarose e de Amido}

$\mathrm{Na}$ maioria das células vegetais as trioses-fosfato produzidas durante a fixação do $\mathrm{CO}_{2}$ são convertidas primariamente em sacarose e amido ou utilizadas na sintese de aminoácidos (Stitt \& Sonnewald, 1995). Comunicação e coordenação entre a síntese de sacarose no citosol, a fixação de carbono e a sintese de amido no cloroplasto são mediados pelo sistema transportador de P,-triose fosfato (Flügge \& Heldt, 1991; Sharkey et al., 1986). A taxa de sintese de sacarose deve estar ajustada de maneira que a quantidade 
suficiente de fosfato inorgânico seja liberada para manter sua concentração no estroma e permitir que as reações ocorram eficientemente no estroma e tilacóide, caso contrário a fotossintese pode ser inibida. Portanto, o equilíbrio entre estes processos é regulado rigidamente e ambos precisam ser coordenados com a velocidade de fixação de carbono (Flügge \& Heldt, 1991).

A fotossintese será também inibida se houver uma retirada muito rápida de triose- $P$, pois isto leva a uma diminuição nos metabólitos do ciclo de Calvin-Benson e a conseqüente redução na concentração de RuBP, o substrato para a fixação do $\mathrm{CO}_{2}$ (Stitt, 1987; Stitt et al., 1988). A regulação da sintese de sacarose também pode interferir na alteração do fracionamento dos fotossintetatos de modo a permitir que a sintese de amido seja maior. Se a síntese de sacarose é muito rápida, o transporte do excesso de $P_{1}$ para o interior do cloroplasto resultará na remoção de muitas trioses-P; ocasionando um efeito deletério na velocidade de fixação de carbono visto que cinco de cada seis moléculas de triose-P produzidas no ciclo de Calvin são necessárias para regenerar a RuBP e completar o ciclo. Por outro lado, se a sintese de sacarose é muito lenta, $P_{1}$ em quantidade insuficiente será colocado em disponibilidade para a sintese de triose-P no interior dos cloroplastos (Stitt, 1990).

Há dois sistemas enzimáticos com total capacidade para catalisar a produção de sacarose:
sacarose fosfato sintase
sacarose fosfatase
1- UDP-glucose + frutose-6fosfato UDP + sacarose-6fosfato $\longrightarrow$ sacarose $+P_{l}$
2- UDP-glucose + frutose $\underset{\text { sacarose sintase }}{\longrightarrow}$ UDP + sacarose

As duas rotas são teoricamente possiveis, entretanto, as evidências disponiveis indicam que a maior parte da sintese de sacarose ocorre via sacarose fosfato sintase/sacarose fosfatase. É que a atividade da sacarose sintase parece estar restrita à clivagem da sacarose em certas situações onde a 
concentração desse metabólito encontra-se excessivamente elevada (Lea \& Leegood, 1995).

O amido é o principal polissacarídeo de armazenamento em plantas e está presente em todos os principais órgãos. Nas folhas, o seu armazenamento se dá, quando o acúmulo de sacarose em determinadas situações é maior do que a taxa de exportação desse carboidrato. Então, durante o período luminoso, o amido acumulado temporariamente no interior dos cloroplastos é degradado posteriormente no período de ausência de luz. Assim, alguns autores acreditam que a sintese de amido funcione tamponando os cloroplastos permitindo que a fotossintese seja mantida em altíssimas taxas (Martin \& Smith, 1995).

A rota predominante da síntese de amido dentro dos cloroplastos, é a via catalisada pela enzima ADP-Glucose Pirofosforilase (AGPase). Essa enzima é fortemente ativada por 3-PGA e inibida por fosfato inorgânico $\left(P_{i}\right)$, e a regulação baseia-se em mudanças na propriedade cinética da enzima (Preiss, 1988; Preiss, 1991). Outros intermediários glicolíticos como o fosfoenolpiruvato, frutose-1,6-bifosfato e frutose-6-fosfato, também ativam a enzima quando em altas concentrações. Devido à alta sensibilidade da enzima AGPase a 3-PGA e $P_{i}$, foi proposto e depois concluído, que estes dois compostos têm um importante papel na regulação da biossíntese do amido (Preiss \& Levi, 1980). Foi observado em cloroplastos isolados que uma diminuição no fornecimento de $P_{i}$ leva a um decréscimo na relação ATPIADP e uma restrição na redução de 3$P G A$. Isto resulta em aumento da relação 3-PGA/ $P_{i}$ que ativa a enzima AGPase, aumentando a síntese de amido. A regulação desta enzima in vivo tem duas funções: 1) a ativação pelo aumento da relação 3-PGA/P i estimula a síntese de amido em resposta ao aumento de metabólitos, e 2) a inibição pela queda da relação 3-PGA/ $P_{\mathrm{i}}$ protege contra um dreno excessivo de triose-P para amido no interior dos cloroplastos (Stitt \& Sonnewald, 1995).

Estabelecido o equilíbrio dinâmico da fixação dos átomos de carbono, todas estas atividades se ajustam de forma tal que a síntese de 
sacarose e do amido consomem, cada uma, perto de $50 \%$ das trioses-P produzidas durante a fixação do carbono. Além disso, as velocidades desses dois processos são reguladas de tal forma que as concentrações dos precursores e intermediários necessários para fixação do carbono são mantidos em niveis ótimos (Beck \& Ziegler, 1989).

\section{4- Estresse oxidativo}

O aparecimento dos seres aeróbicos foi um marco na evolução, pois o emprego de oxigênio aumentou consideravelmente a extração de energia dos alimentos consumidos. Entretanto, em decorrência de sua configuração eletrônica, a molécula de oxigênio tem forte tendência a receber um elétron de cada vez, formando durante as reações, espécies intermediárias de oxigênio altamente reativas (Elstner, 1982).

Nas plantas, a transferência de elétrons ao oxigênio ocorre em muitos compartimentos celulares, mas é mais marcante nos cloroplastos iluminados em decorrência da altíssima concentração de oxigênio no interior dessa organela. Sabe-se que durante o período luminoso, o cloroplasto tornase rapidamente o compartimento mais aeróbico da natureza. A $25^{\circ} \mathrm{C}$, a concentração de $\mathrm{O}_{2}$ no interior dos plastídeos fotossintetizantes é estimada entre $275 \mu \mathrm{M}$ a $300 \mu \mathrm{M}$ (Robinson, 1988).

Um inevitável problema para as plantas expostas à alta luminosidade, refere-se à quantidade de luz absorvida pelo aparato fotossintético superior àquela necessária à fixação de $\mathrm{CO}_{2}$ nas reações bioquímicas independentes de luz (Scandalios, 1993). Isso faz com que o excesso de energia seja desviado às abundantes moléculas de $\mathrm{O}_{2}$, através da reação de Mehler, gerando as espécies de oxigênio reativas (ROS), tais como radicais superóxidos, peróxido de hidrogênio, radical hidroxila e a forma energizada do oxigênio no estado "singlet". Segundo Allen (1995), quando a 
fixação de $\mathrm{CO}_{2}$ é limitada por condições ambientais tais como baixas temperaturas ou baixa disponibilidade de $\mathrm{CO}_{2}$ (fechamento estomatal), a excessiva redução do PSI e o aumento na produção de ROS pode ocorrer mesmo em moderadas intensidades de luz.

Para combater a constante presença das espécies ROS, as plantas desenvolveram mecanismos enzimáticos e não enzimáticos de defesa (Alscher et al., 1997). Na classe não enzimática, enquadram-se a glutationa reduzida, cisteína, hidroquinonas, manitol, vitaminas $\mathrm{C}$ e $\mathrm{E}$, flavonóides, alguns alcalóides e $\beta$-caroteno (Larson et al., 1988). Representando as defesas enzimáticas encontram-se as catalases (CAT), superóxidos dismutases (SOD), glutationas redutases (GR) e ascorbato peroxidases (APX).

Nos cloroplastos os radicais superóxidos são produzidos pela reação do oxigênio molecular com o PSI via a reação de Mehler. Esse superóxido é rapidamente dismutado à $\mathrm{H}_{2} \mathrm{O}_{2}$ pela $\mathrm{SOD}$ associada às membranas do tilacóide. $\mathrm{O}_{2} \mathrm{H}_{2}$ produzido é rapidamente eliminado pela ascorbato peroxidase presente no mesmo conjunto membranoso. O superóxido e $\circ \mathrm{H}_{2} \mathrm{O}_{2}$ que eventualmente escaparem da degradação dessas enzimas são capturados e degradados por isoformas presentes no estroma (Allen, 1995). Radicais monohidroascorbato produzidos pela APX podem ser rapidamente reduzidos à ácido ascórbico via Ferredoxina $(\mathrm{Fd})$ ou pela monodehidroascorbato redutase estromal. Alternativamente, eles podem ser convertidos espontaneamente à ácido ascóbico pela dehidroascorbato redutase usando glutationa reduzida como doadora de elétrons (Inzé \& Van Montagu, 1995). A subsequente regeneração da glutationa reduzida requer glutationa redutase (GR) e NADPH.

Todas as espécies ROS são extremamente citotóxicas e reativas, pois reagem com ácidos graxos não saturados, causando a peroxidação de lipídios essenciais das membranas do plasmalema ou das organelas intracelulares afetando a atividade respiratória em mitocôndrias (Scandalios, 1993) e perda da capacidade de fixação nos cloroplastos, devido ao fato de que 
concentrações tão baixas quanto $10 \mu \mathrm{M}$ de $\mathrm{H}_{2} \mathrm{O}_{2}$ inibem 0 processo fotossintético em $50 \%$ (Kaiser, 1979). Proteínas, ácido nucléicos e clorofilas são também alvos potenciais do ataque dessas substâncias altamente tóxicas (Scandalios, 1993).

Segundo Scandalios (1990), em adição à atividade metabólica normal, as espécies de oxigênio reativas podem ser formadas ao expor células à vários estímulos ambientais tais como radiação UV, herbicidas (paraquat e diquat), patógenos, injúrias mecânicas, hiperoxia, ozônio, flutuações de temperatura e vários outros tipos de estresse conhecidos por induzirem a formação de radicais livres em muitos organismos aeróbicos.

\subsection{1- Superóxido dismutase (SOD)}

As SODs são um grupo de enzimas que convertem o radical superóxido em $\mathrm{H}_{2} \mathrm{O}_{2}$ (Scandalios, 1993). Três classes distintas de SODs foram detectadas em plantas e estão classificadas de acordo com seus cofatores metálicos: $\mathrm{Mn}, \mathrm{Fe}$ ou Cu/Zn (Bowler et al., 1992). A SOD-Mn está localizada nas mitocôndrias, mas uma SOD-Mn associada às membranas foi encontrada nos cloroplastos em algumas plantas (Hayakawa et al., 1984). A SOD-Fe não tem sido detectada em todos os estudos, mas quando encontrada, aparece associada aos cloroplastos (Casano et al., 1994; Van Camp et al., 1994; Donahue, 1997). Segundo Matters e Scandalios (1986), Tsang et al. (1991); Sen Gupta et al. (1993) e Rao et al. (1996), as abundantes SODs-Cu/Zn são geralmente encontradas no citosol e cloroplastos de células eucarióticas.

\subsection{2- Catalase (CAT)}

Três iso-enzimas CAT geneticamente distintas foram caracterizadas em plantas de milho (Scandalios et al., 1994) e apenas duas têm sido identificadas em cevada (Skadsen et al., 1995). Segundo Willekens et al. 
(1997), Nicotiana plumbaginifolia contém 3 genes ativos codificando a catalase (cat1, cat2 e cat3), dois dos quais expressos em folhas maduras (cat1 e cat2). Cat3 é abundante nos glioxisomas dos tecidos armazenadores de lipidios, onde ela decompõe $\mathrm{H}_{2} \mathrm{O}_{2}$ formado durante a $\beta$-oxidação dos ácidos graxos (Holtman et al., 1994). Cat1 representa $80 \%$ da atividade catalase e está localizada no interior dos peroxissomos das células do parênquima palissádico, onde ela converte $\circ \mathrm{H}_{2} \mathrm{O}_{2}$ produzido durante a fotorrespiração na conversão de glicolato em glioxilato em $\mathrm{H}_{2} \mathrm{O}$ e $\mathrm{O}_{2}$ (Kendall et al., 1983, Willekens et al. 1997). Por último, Cat2 representa aproximadamente $20 \%$ da atividade total e é encontrada no tecido vascular e pode estar envolvida na proteção contra o estresse ambiental (Willekens et al., 1994). As isoformas CAT em vários trabalhos são mostradas como sendo reguladas temporal e espacialmente, e podem responder diferencialmente à luz (Havir \& McHale, 1989, Scandalios et al., 1994; Willekens et al., 1994, Skadsen et al., 1995).

\subsection{3- Glutationa redutase (GR)}

No ciclo ascorbato-glutationa, responsável pela eliminação do $\mathrm{H}_{2} \mathrm{O}_{2}$ formado no interior dos cloroplastos, o último passo é catalisado pela enzima glutationa redutase (GR) (Inzé \& Van Montagu, 1995).

Segundo Creissen e colaboradores (1994) em condições de estresse oxidativo o nivel de atividade de GR aumentou duas vezes em plantas de espinafre. Aumento similares foram observados em plantas de ervilhas expostas à poluentes. $\mathrm{O}$ aparente relacionamento entre estresse oxidativo e elevadas atividades das enzimas do ciclo ascorbato-glutationa, incluindo GR, tem despertado interesse e vem sendo objeto de estudo de vários grupos de pesquisa (Inzé \& Van Montagu, 1995). De todas as enzimas envolvidas no processo, a GR é a que tem recebido maior atenção (Creissen et al., 1994).

Nas folhas de ervilha a GR esta presente nos cloroplastos, mitocôndrias e compartimentos citosólicos (Edwards et al., 1990). Essas 
enzimas são codificadas por genes nucleares e cDNAs codificando a GR de ervilha e tabaco foram recentemente isolados e sequenciados. As seqüências de aminoácidos derivadas desses cDNAs, apresentam substancial homologia com as GRs de bactérias e mamíferos, porém possuem na região amino terminal um possível peptídeo de trânsito para os cloroplastos. Entretanto a organização genômica da família de genes da GR não foi ainda completamente elucidada (Foyer et al., 1997).

\section{5- Hemoglobinas de Plantas}

As hemoglobinas vegetais são hemoproteínas que estão amplamente distribuídas em plantas superiores $e$, de forma semelhante às mioglobinas de vertebrados, apresentam alta afinidade pelo oxigênio. Comparando as seqüências, padrões de expressão e propriedades cinéticas de associação/dissociação, torna-se evidente que essas proteínas estão divididas em dois grandes grupos: as hemoglobinas simbiontes e as não simbiontes (Anderson et al., 1996).

As leghemoglobinas (hemoglobinas simbiontes) são proteínas de aproximadamente $16 \mathrm{kDa}$, que desempenham papel importante nos nódulos das raízes de leguminosas infectadas por bacterióides simbiontes do gênero Rhyzobium, responsáveis pela fixação do nitrogênio. Elas facilitam a difusão do oxigênio do plasmalema de células infectadas até a membrana periplasmática do bacterióide ( $\mathrm{Ji}$ et al., 1992). O rápido bombeamento do oxigênio pela leghemoglobina assegura baixa pressão parcial de $\mathrm{O}_{2}$ no interior do bacterióide, favorecendo a atividade do complexo nitrogenase, já que este é rapidamente inativado de forma irreversivel em condições aeróbicas (Becana \& Klukas, 1992). A função dessa hemoglobina simbionte seria portanto, facilitar a difusão do oxigênio das células infectadas para a membrana peribacterióide, por onde ele se difunde até alcançar a oxidase terminal do bacterióide, onde é utilizado na oxidação dos carboidratos que foram fornecidos pela plantas (Appleby, 
1984). Os estágios resultantes serão essenciais na redução do $\mathrm{N}_{2}$ à $\mathrm{NH}_{3}$, já que a primeira forma nitrogenada não é assimilável pelos vegetais. Porém, para realizar esta função, é necessário que a leghemoglobina encontre-se em seu estado ferroso $\mathrm{Lb}^{+2}$, isto é, reduzido (Ackrell, et al., 1972). Vários grupos de pesquisa, sugerem que existe nos nódulos um sistema para reduzir a $\mathrm{Lb}^{+3}$. Appleby (1984) mostrou que bacterióides podem reduzir lentamente a $\mathrm{Lb}^{+3}$ a $\mathrm{Lb}^{+2}$ sob condições anaeróbicas, sugerindo que existe uma enzima envolvida no processo. Em 1977, Kretovich e colaboradores, conseguiram a purificação parcial da enzima FLbr (leghemoglobina redutase férrica) nos nódulos de Lupinus sp. Mais recentemente, um cDNA que codifica a mesma enzima foi clonado e sequenciado por Ji et al. (1994), revelando a existência de uma seqüência de direcionamento mitocôndrial. Descobriu-se também, que nos nódulos estão presentes muitos redutores em potencial da $\mathrm{Lb}^{+3}$. Dentre eles, podemos citar o $\mathrm{NADPH}$, ascorbato, glutationa reduzida e cisteina ( $\mathrm{Ji}$ et al., 1994). Porém, nos nódulos também encontram-se em abundância certos metabólitos como nitrito, radicais superóxidos, peroxidases, íos metálicos e quelantes (Rigaud \& Puppo, 1977) que podem oxidar a $\mathrm{Lb}^{+2}$, formando $\mathrm{Lb}^{+3}$, que não se liga ao $\mathrm{O}_{2}$, principalmente se $\mathrm{opH}$ do meio intra-nodular estiver ligeiramente ácido (Ji et al., 1994).

As leghemoglobinas pertencem a uma família multigênica (Brisson \& Verma, 1982) e são codificadas por genes que possuem três introns. Interessante é que o primeiro e o terceiro íntrons estão em posições similares às dos íntrons dos genes que codificam hemoglobinas de vertebrados, sugerindo que as hemoglobinas vegetais e animais derivam de um ancestral comum (Arredondo-Peter et al., 1998).

As leghemoglobinas são as proteinas mais abundantes nos nódulos das raízes. Elas representam aproximadamente 25\% das proteínas solúveis totais nas células infectadas e conferem uma cor caracteristica rosaavermelhada aos nódulos (Arredondo-Peter et al., 1998). Segundo Hill (1998), para realizar sua adequada função na difusão do oxigênio, a concentração 
dessa proteína deve ser elevada o suficiente para criar um gradiente onde a leghemoglobina se associa ao oxigênio mais rapidamente que sua taxa de difusão. Além disso, o autor estima que a relação leghemoglobina/oxigênio nos nódulos esteja em torno de 10.000 vezes. Para verificar a grandeza desse número, basta compará-lo com a relação mioglobina/oxigênio nas células do músculo do coração de vertebrados que é de apenas 30 vezes.

O segundo grupo de hemoglobinas vegetais representado pelas hemoglobinas não simbiontes, provavelmente, trata-se do ancestral das hemoglobinas simbiontes. As não simbiontes estão mais amplamente distribuídas no Reino vegetal e, geralmente, apresentam alta afinidade pelo oxigênio (Arredondo-Peter et al., 1998). Anderson et al. (1996) isolaram um gene que codifica uma leghemoglobina não simbionte em soja. Os autores sugerem que esta proteina funcione de forma a facilitar a difusão intracelular do oxigênio para as mitocôndrias, em células que demandam grande quantidade de energia.

A presença da hemoglobina não simbionte em diversas plantas, incluindo monocotiledôneas (Taylor et al., 1994), sugere que esta proteína contribua para o crescimento e desenvolvimento de uma forma que vai além de sua função no processo de fixação do nitrogênio. Sowa et al. (1998) sugerem que as hemoglobinas não simbiontes tenham por função manter o estado energético da célula em condições de hipoxia ou sob alta demanda de energia.

Plantas transgênicas de tabaco expressando hemoglobina de Vitreoscilla mostraram uma maior taxa de crescimento devido, ao menos em parte, ao aumento do teor de clorofila verificado nessas plantas. O aumento no estoque de ATP e oxigênio devido à hemoglobina, os quais são usados em vários estágios da biossíntese de clorofila, pode ser a causa indireta dessa aceleração de crescimento e desenvolvimento (Holmberg et al., 1997).

Devido ao encontro de genes de hemoglobinas em gêneros de plantas filogeneticamente distintos, incluindo monocotiledôneas, pode-se supor que as hemoglobinas podem estar presentes em todo o Reino vegetal. 


\section{6- Direcionamento de proteínas aos cloroplastos}

A maior parte das proteínas cloroplásticas são codificadas por genes nucleares e sintetizadas sob a forma de precursores no citosol. Estes precursores apresentam na extremidade amino-terminal, uma sequência de direcionamento chamada de peptideo de trânsito, que é responsável pela translocação do precursor ao interior da organela (de Boer \& Weisbeek, 1991).

Este processo de importação de proteínas é específico (Boutry et al., 1987; Silva-Filho et al., 1996), entretanto em alguns casos esta especificidade não foi observada (Huang et al., 1990; Hurt et al., 1986 e Pfaller et al., 1989; Silva-Filho, 1999). Recentemente, Creissen e colaboradores (1995) demonstraram que a proteína glutationa redutase de ervilha é direcionada simultaneamente às mitocôndrias e cloroplastos. Em alguns casos, o peptídeo de trânsito não é capaz de introduzir uma proteína "reporter" no interior dos cloroplastos, havendo a necessidade de aminoácidos presentes na extremidade amino terminal da proteína madura para eficiente importação(Kavanagh et al., 1988; Silva-Filho et al., 1997).

As observações de que o peptídeo de trânsito é capaz de transportar proteinas estrangeiras ao interior dos cloroplastos, abrem novas perspectivas no estudo dos processos biológicos que ocorrem nestas organelas. Novas proteínas podem ser introduzidas com o objetivo de alterar a fisiologia das plantas, como por exemplo, melhorar a fotossintese, gerar plantas resistentes a herbicidas, além de proporcionar um vasto campo de trabalho no entendimento dos fenômenos biológicos tão importantes para o funcionamento das plantas. 


\section{3- MATERIAL E MÉTODOS}

\section{1- Espécie vegetal}

Por se tratar de uma espécie representante do metabolismo $\mathrm{C}_{3}$ e apresentar protocolos de transformação padronizados, plantas de Nicotiana tabacum cv SRI foram usadas na transformação gênica.

\section{2- Vetores bacterianos}

O plasmídeo binário Bin2-35ScatE9' (Chaumont et al., 1994), capaz de replicar tanto em Escherichia coli e Agrobacterium tumefaciens, foi usado na transformação de plantas de tabaco. A este plasmídeo foram ligados os fragmentos Iba (que codifica para a leghemoglobina de soja) e rbcS-Iba (que corresponde ao gene $\mathrm{lba}$, ligado à sequência de direcionamento para o cloroplasto), dando origem aos plasmídeos: Bin2-35S/baE9 e Bin2-35SrbcSIbaE9' (Figura 4). 
a) $r b c S-I b a$

LB

RB

nptll $35 S$

rbcs

Link

Lba

E9

$[\because \because \ddots \ddots r 1$

4

AAGCTTTGCAATTCATACAGAAGTTGAGAAAAATGGCTTCTATGATATCCTCT $M \quad A \quad S \quad M \quad I \quad S \quad S$

TCCGCTGTGACAACAGTCAGCCGTGCCTCTAGGGGGCAATCCGCCGCAGTG $S A \quad V \quad T \quad T \quad V \quad S \quad R \quad A \quad S \quad R \quad G \quad N \quad S \quad A \quad A \quad V$ GCTCCATTCGGCGGCCTCAAATCCATGACTGGATTCCCAGTGAAGAAGGTC
$\begin{array}{lllllllllllllllll}A & P & F & G & G & L & K & S & M & T & G & F & P & V & K & K & V\end{array}$

AACACTGACATTACTTCCATTACAAGCAATGGTGGAAGAGTAAAGTGCATG

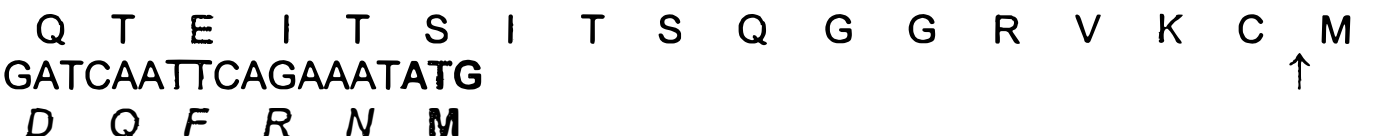

b) Iba

LB $\quad$ RB

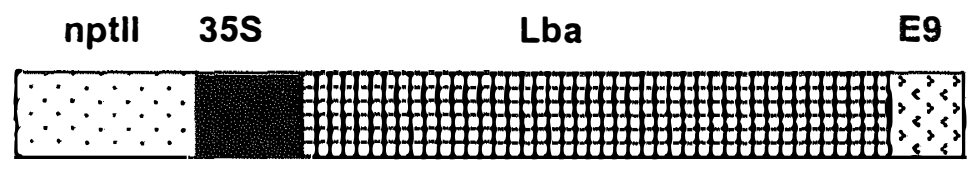

GAATTCAGAAATATGGTTGCTTTC...GCTATTAAGAAGGCATAA

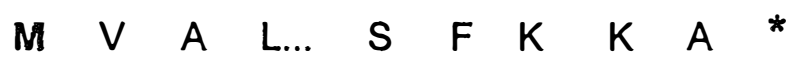

Figura 4: Representação esquemática das construções dos genes quiméricos (a) $35 S$ rbcS-Iba e 35S/ba (b). Abaixo do esquema das construções rbcS-Iba estão mostradas a sequência de nucleotídeos e aminoácidos do peptídeo de trânsito da pequena subunidade da Rubisco (rbcS); assim como a região "linker" "upstream" do códon de iniciação da leghemoglobina. Os resíduos de aminoácidos da região "linker" estão em itálico e o sítio de restrição Hind III sublinhado. Os códons de iniciação da Rubisco e da leghemoglobina estão em negrito e a seta vertical representa o ponto de clivagem entre o peptideo de trânsito e a proteina madura. O desenho não está em escala. 


\section{3- Cepa bacteriana}

Para a transformação de plantas a cepa de Agrobacterium tumefaciens LBA 4404 foi utilizada.

\section{4- Meios de cultura}

Para crescimento de $A$. tumefaciens: o meio de Luria-Bertani (LB) foi composto de $1 \%(\mathrm{p} / \mathrm{v})$ de bacto-triptona (DIFCO), $0,5 \%(\mathrm{p} / \mathrm{v})$ de extrato de levedo (DIFCO), $1 \%$ (p/v) de $\mathrm{NaCl}, \mathrm{pH} \mathrm{7,5}$, acrescido de Kanamicina e Rifampicina $(0,01 \% \mathrm{p} / \mathrm{v})$. Quando necessário, $0,8 \%$ de bacto-ágar (DIFCO) foi adicionado ao meio.

Para a transformação e crescimento das plantas, o meio de Murashige e Skoog (1962) foi adquirido da SIGMA e suplementado com 3\% $(\mathrm{p} / \mathrm{v})$ de sacarose e $0,8 \%(\mathrm{p} / \mathrm{v})$ de ágar. Dois outros meios baseados no $\mathrm{MS}$ foram também utilizados: o meio MSAKC que consiste no meio básico MS suplementado com $2 \times 10^{-5} \%(\mathrm{p} / \mathrm{v})$ de ácido indol acético, $0,01 \%(\mathrm{p} / \mathrm{v})$ de Kanamicina, $0,04 \%(p / v)$ de carbenicilina e $0,05 \%(p / v)$ de benzilaminopurina (Silva-Filho, 1994).

\section{5- Transformação de plantas}

Discos foliares medindo aproximadamente $1 \mathrm{~cm}^{2}$ foram colocados em placas contendo o meio MS e perfurados com agulhas estéreis, previamente imersas numa cultura fresca de Agrobacterium tumefaciens. Após três a quatro dias, as bactérias presentes nos discos foliares foram mortas colocando-as num meio contendo os antibióticos cefotaxime e carbenicilina. A partir de 15 dias após a transferência ao meio MSACKC, ocorreu o aparecimento de plântulas (organogênese direta). $O$ desenvolvimento de raízes foi favorecido pela transferência das plântulas ao meio MSAKC. 


\section{6- Extração de DNA das plantas}

A extração de DNA foi efetuada usando-se o protocolo descrito por Edwards et al., (1991). Discos foliares com cerca de $0,5 \mathrm{~cm}^{2}$ foram coletados usando a tampa estéril do próprio tubo tipo Eppendorf. O tecido foi macerado sem adição de tampão à temperatura ambiente por 15 segundos. Foram adicionados $400 \mu \mathrm{L}$ de tampão de extração $(200 \mathrm{mM}$ de Tris $\mathrm{HCl}$ pH 7,5, $200 \mathrm{mM}$ de $\mathrm{NaCl}, 25 \mathrm{mM}$ de EDTA e $0,5 \%$ de SDS) e os tubos Eppendorfs agitados por 5 segundos. O extrato foi, então, centrifugado (13.000 rpm em microcentrífuga) por 1 minuto e $300 \mu \mathrm{L}$ do sobrenadante foram transferidos para novos Eppendorfs. Após esse procedimento, foram adicionados $300 \mu \mathrm{L}$ de isopropanol e a solução resultante foi deixada em repouso por 2 minutos em temperatura ambiente. Os tubos Eppendorffs foram centrifugados $(13.000 \mathrm{rpm}$ em microcentrifuga) por 5 minutos e os sobrenadantes descartados. Os precipitados, após a secagem, foram dissolvidos em $100 \mu \mathrm{L}$ de $1 \mathrm{X}$ Tris EDTA (TE) composto de $10 \mathrm{mM}$ de Tris- $\mathrm{HCl}$ pH 7,6 e $1 \mathrm{mM}$ de EDTA pH 8,0.

\section{7- Verificação da presença do T-DNA nas plantas}

A caracterização das plantas obtidas por regeneração in vitro foi realizada, através de reação por PCR (Reação da Polimerase em Cadeia).

Os seguintes oligonucleotídeos (primers) foram utilizados.

- Para as plantas provenientes da transformação com a construção Bin235S/baE9:

Primer leg: 5'-CCCGAATTCAGAAATATGGTTGC-3'

Primer leg 2: 5'-CCCGGATCCTACTAATTATGCC-3'

- Para as plantas obtidas por transformação com a construção Bin235SrbcSIbaE9:

Primer leg 2: 5'-CCCGGATCCTACTAATTATGCC-3'

Primer rtc 2: 5'-CCATGACTGGATTCCCAGTG-3' 
Para ambas as construções, as condições utilizadas na reação, após otimização, foram as seguintes: $5,0 \mu \mathrm{L}$ de DNA extraído, $0,6 \mu \mathrm{L}$ de dNTP 2,5 mM, 1 unidade de Taq DNA polimerase, 5,0 $\mu \mathrm{L}$ de tampão de reação 10 vezes concentrado e 40 pmoles de cada primer.

A reação de amplificação total utilizada nas duas construções foi composta de 35 ciclos, cada um constituído de desnaturação $\left(95^{\circ} \mathrm{C}\right.$ por 45 segundos), anelamento $\left(55^{\circ} \mathrm{C}\right.$ por 45 segundos) e elongação $\left(73^{\circ} \mathrm{C}\right.$ por 150 segundos).

\section{8- Extração de proteínas totais}

Para a extração de proteínas totais, cerca de 1 grama de folha fresca foi macerado em nitrogênio líquido e cerca de $2,5 \mathrm{~mL}$ de tampão de extração composto de 0,1M de TrisCl pH 7,6 e 0,1\% (p/v) de ácido ascórbico foi adicionado. Ao descongelar, o extrato foi recolhido em tubos Eppendorfs e centrifugado por 2 minutos à $14.000 \mathrm{rpm}$ em microcentrifuga. Após a centrifugação o sobrenadante foi coletado em novos tubos Eppendorfs e armazenados à $-80^{\circ} \mathrm{C}$ para as posteriores análises.

\section{9- Análise da concentração de proteínas}

O teor de proteína no extrato foi determinado com base no método descrito por Bradford (1976), onde $10 \mu \mathrm{L}$ de extrato das amostras foram adicionados a $1 \mathrm{~mL}$ do reagente de Bradford (50mg Coomassie Briliant Blue G250 , dissolvido em $25 \mathrm{~mL}$ de etanol, aos quais adiciona-se $50 \mathrm{~mL}$ de ácido fosfórico e completa-se o volume a $500 \mathrm{~mL}$ com água) para reagir por 2 minutos. Após a reação, determinou-se a concentração protéica das amostras via espectrofotômetro com base na densidade ótica a $595 \mathrm{~nm}$ tomando-se como 
base uma curva padrão construída com BSA (soro albumina bovina) em concentrações de proteinas variando de 0,5 a $5,0 \mu \mathrm{g}$.

\subsection{0- Eletroforese e imunodetecção}

\subsection{1- Solubilização de proteínas e eletroforese}

As proteínas $(\sim 10 \mu \mathrm{g})$ foram solubilizadas em $80 \mathrm{mM}$ de Tris-Cl, $2 \%(p / v)$ de SDS, $10 \%(p / v)$ de glicerol, 0,005\% $(p / v)$ de azul de bromofenol e $1 \%(\mathrm{p} / \mathrm{v})$ de dithiothreitol, $\mathrm{pH} 6,8(\mathrm{HCl})$ por 15 minutos a $56^{\circ} \mathrm{C}$, e então separadas eletroforeticamente por SDS em gel de poliacrilamida (Laemmli, 1970), a voltagem constante de $100 \mathrm{~V} / g e l$. As proteinas foram transferidas para uma membrana de nitrocelulose $0,45 \mu \mathrm{m}$ da BioRad (Towbin et al., 1979) utilizando amperagens de: $75 \mathrm{~mA}$ por 12 minutos, $175 \mathrm{~mA}$ por 15 minutos, $400 \mathrm{~mA}$ por 25 minutos e, finalmente, $450 \mathrm{~mA}$ por 10 minutos.

\subsection{2- Imunodetecção}

Após a transferência, a membrana de nitrocelulose foi lavada, sob agitação, com aproximadamente $50 \mathrm{~mL}$ de tampão fosfato salino (PBS) composto de 136,9 mM de NaCl, 2,68 mM de KCl, 30,25 mM de $\mathrm{NaH}_{2} \mathrm{PO}_{4}, 1,76$ $\mathrm{mM}$ de $\mathrm{KH}_{2} \mathrm{PO}_{4}, \mathrm{pH} \mathrm{7,4)}$ durante 5 minutos. A seguir, foi saturada com uma solução contendo $5 \%$ de leite em pó desnatado e $0,2 \%(v / v)$ de Tween 20 . A membrana foi lavada 3 vezes por 10 minutos com tampão tris salino (TBS) + $0,1 \%(v / v)$ Tween 20, e incubada por 1 hora com anticorpo anti-leg (gentilmente cedido pelo Dr. Gautam Sarath, do Departamento de Bioquímica da Universidade de Nebraska-USA), em TBS (diluição 1/1.000). Após a incubação

com o anticorpo primário, a membrana foi novamente lavada 3 vezes por 10 minutos em TBS contendo $0,1 \%$ de Tween $20(\mathrm{v} / \mathrm{v})$ e incubada por uma hora com o anticorpo secundário anti-goat lgG conjugado com a fosfatase alcalina 
(SIGMA) na diluição de 1/10.000. Novamente, a membrana foi lavada 3 vezes por 10 minutos em TBS contendo $0,1 \%$ de Tween $20(\mathrm{v} / \mathrm{v})$ e revelada com o produto FAST BCIPINBT (SIGMA), conforme recomendações do fornecedor.

\subsection{1- Preparo do extrato foliar para determinação de sacarose e amido}

Discos foliares de aproximadamente $10 \mathrm{~cm}^{2}$ foram usados para a determinação de sacarose e amido.

A extração foi realizada em $10 \%(\mathrm{v} / \mathrm{v})$ de ácido perclórico, conforme descrito por Labate e Leegood (1989): o disco foliar congelado foi colocado em um almofariz pré-resfriado e macerado até completa pulverização em nitrogênio líquido com $1 \mathrm{~mL}$ de $\mathrm{HClO}_{4}$ 10\% (v/v). Em seguida, o almofariz foi lavado com $0,5 \mathrm{~mL}$ de $\mathrm{HClO}_{4} 1 \%(\mathrm{v} / \mathrm{v})$. A amostra foi centrifugada a aproximadamente $14.000 \mathrm{rpm}$ (microcentrifuga) por dois minutos. Após marcarse o volume do tubo, tomado como volume do extrato, o sobrenadante foi transferido para outro tubo e o precipitado verde foi usado para a determinação da feofitina, conforme descrição abaixo. $\mathrm{O}$ sobrenadante foi neutralizado a $\mathrm{pH}$ 6,5-7,0 com $\mathrm{K}_{2} \mathrm{CO}_{3} 5 \mathrm{M}$ e em seguida, acrescido de $200 \mu \mathrm{L}$ de uma suspensão de carvão ativado $(200 \mathrm{mg} / \mathrm{mL})$. Centrifugou-se por mais dois minutos a 14.000 rpm (microcentrifuga) e o sobrenadante foi utilizado para análise de metabólitos e o precipitado descartado.

\subsection{1- Determinação de feofitina}

Em condições de extração ácida, a clorofila é convertida a feofitina, sendo determinada de acordo com o método de Vernon (1960): o precipitado verde resultante da extração de $\mathrm{HClO}_{4}$, foi transferido para tubo de vidro com $10 \mathrm{~mL}$ de acetona $80 \%(\mathrm{v} / \mathrm{v})$, agitado e deixado durante uma noite à temperatura ambiente, para a completa extração dos pigmentos. Em seguida, foi centrifugado a $3.500 \mathrm{rpm}$ no rotor Sorvall ST-micro por cinco minutos e a 
absorbância foi medida contra uma prova em branco de acetona $80 \%$ a 666 e $655 \mathrm{~nm}$ e o conteúdo de feofitina foi calculado utilizando a seguinte fórmula:

$m g$ de feofitina. $m L^{-1}=\left[\left(26,03 \times A_{655}\right)+\left(6,75 \times A_{666}\right)\right] \times(V / 1000)$

onde:

$A_{655}=$ absorbância a $655 \mathrm{~nm}$

$\mathrm{A}_{666}=$ absorbância a $666 \mathrm{~nm}$

$V=$ volume de acetona $80 \%$

26,03 e 6,75= coeficientes específicos de absorção óptica

\subsection{2- Determinação do conteúdo de sacarose e amido}

Esses metabólitos foram medidos de acordo com metodologia de Lowry e Passonneau (1972) em espectrofotômetro (Expectra Max Plus Molecular Devices) através de reações enzimáticas acopladas que utilizam $\mathrm{NADH}$ ou NADPH. As determinações baseiam-se nas mudanças de absorbância, no comprimento de onda de $340 \mathrm{~nm}$, que ocorre quando o $\mathrm{NADH}$ ou NADPH passam do estado reduzido para o oxidado, ou vice-versa. Foi utilizada a quantidade de $17,5 \mu \mathrm{L}$ de extrato em um volume total de ensaio de $350 \mu \mathrm{L}$, onde a absorbância foi lida ao final de cada reação. As enzimas utilizadas foram da Boehringer Mannhein (Alemanha).

\subsubsection{1- Determinação do conteúdo de sacarose}

A determinação do conteúdo de sacarose foi realizado adicionando-se 0,5 unidade de glucose-6-fosfato desidrogenase (G6P-dh), 0,5 unidade de fosfoglucose isomerase, 3 unidades de hexoquinase e 100 unidades de $\beta$-frutosidase em tampão contendo $100 \mathrm{mM}$ de Hepes (N-2- 
hidroxietilpiperazine- $\mathrm{N}$ ácido 2-etanosulfônico) $\mathrm{pH}$ 7,0, $5 \mathrm{mM}$ de $\mathrm{MgCl}_{2}, 0,5 \mathrm{mM}$ de DTT (ditiotreitol), 0,02\% (p/v) de BSA (soro de albumina bovina), 0,4 mM de $\mathrm{NADP}^{+}$e $1 \mathrm{mM}$ de ATP.

A quantificação da sacarose foi feita monitorando-se a alteração da densidade ótica a $340 \mathrm{~nm}$. Os produtos de hidrólise da sacarose pela $\beta$ frutosidase (glucose e frutose) são convertidos a glicose-6-fosfato conforme as reações abaixo:

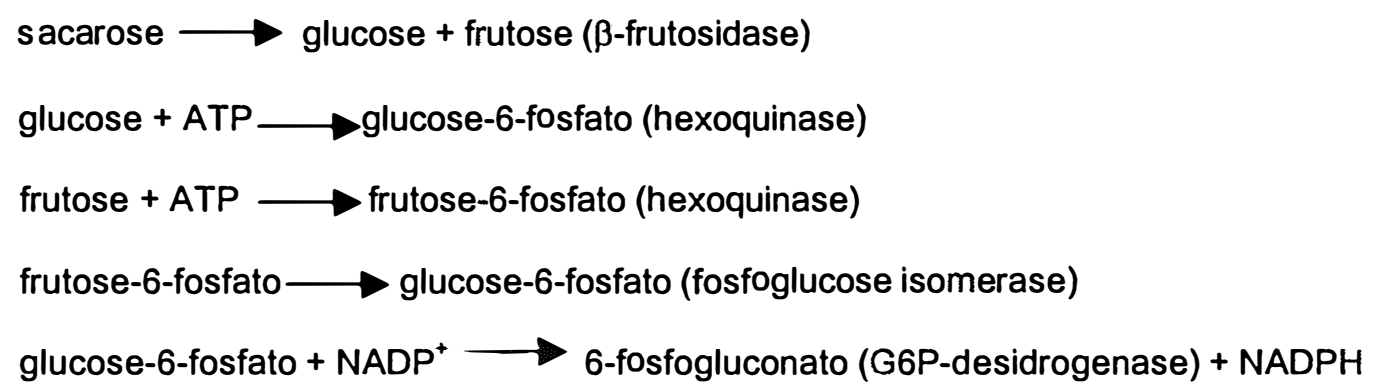

Frutose-6-fosfato é oxidada a 6-fosfogluconato com a redução de $\mathrm{NADP}^{+}$a NADPH.

\subsubsection{2- Determinação do conteúdo de amido}

Para análise do amido, este foi primeiramente hidrolisado à glicose. O precipitado resultante da extração de feofitina foi lavado três vezes com 0,5 mL de tampão MES (ácido 2[N-morfolino]etano-sulfônico) 0,5M (pH 4,5). Em seguida este precipitado foi ressuspendido em $0,5 \mathrm{~mL}$ de tampão MES $0,5 \mathrm{M}(\mathrm{pH} 4,5)$, ao qual foram acrescentadas 14 unidades de amiloglucosidase e 0,4 unidades de $\alpha$-amilase, deixando-se à temperatura ambiente por uma noite. Em seguida, a suspensão foi centrifugada $(14.000 \mathrm{rpm}$ no rotor Sorvall STmicro), o precipitado descartado e o sobrenadante utilizado para determinação de glucose, seguindo a metodologia de Jones et al. (1977). 
A mistura de reação para esta determinação continha $100 \mathrm{mM}$ de tampão Hepes (pH 7,0), $5 \mathrm{mM}$ de $\mathrm{MgCl}_{2}, 0,5 \mathrm{mM}$ de DTT, $0,02 \%(\mathrm{p} / \mathrm{v})$ de BSA, $40 \mathrm{mM}$ de $\mathrm{NADP}^{+}$e $0,1 \mathrm{mM}$ de ATP. Foram acrescentadas 3 unidades de hexoquinase e 0,5 unidades de glucose-6-fosfato desidrogenase (G6P-dh). O esquema abaixo mostra as reações envolvidas na quantificação de amido com base na quantidade de glucose resultante da hidrólise do amido

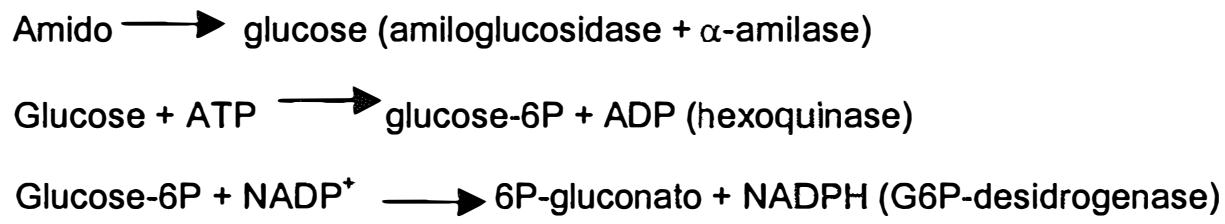

A quantificação de glucose foi feita monitorando-se a variação na densidade ótica a 340nm durante a conversão de glucose-6-fosfato a 6fosfogluconato.

\subsection{2- Determinação do conteúdo de clorofila $a$ e clorofila $b$}

A determinação do conteúdo das clorofilas $a$ e $b$ foi realizada utilizando-se discos foliares de aproximadamente $10 \mathrm{~cm}^{2}$. O tecido foliar foi macerado em nitrogênio líquido e adicionou-se $10 \mathrm{~mL}$ de acetona $80 \%$ tamponada à $\mathrm{pH} 7,8$ (20\% de tampão fosfato-sódio $2,5 \mathrm{mM} \mathrm{pH} 7,8$ e $80 \%$ de acetona pura), obtendo-se um extrato que foi mantido durante a noite em câmara fria a $4^{\circ} \mathrm{C}$ para a total extração dos pigmentos. As leituras de absorbâncias foram feitas a partir do sobrenadante $(1 \mathrm{ml})$, utilizando-se espectrofotômetro (Spectronic Genesis 5 - Milton Roy) a 663,6 e 646,6nm como descrito por Arnon (1949). A quantificação das clorofilas foi feita utilizando-se as seguintes fórmulas: 
Teor de clorofila $a=\left\{\left[12,25 \times A_{663,6}-2,55 \times A_{646,6}\right] \times V_{\text {total de acetona }}\right\} / 1000$ Teor de clorofila $b=\left\{\left[20,31 \times A_{646,6}-4,91 \times A_{663,6}\right] \times V_{\text {total de acetona }}\right\} / 1000$ Onde:

$A_{663,6}=$ absorbância a $663,6 \mathrm{~nm}$

$A_{646,6}=$ absorbância a $646,6 \mathrm{~nm}$

12,25 e 2,55= coeficientes específicos de absorção ótica para a clorofila a 20,31 e 4,91= coeficientes específicos de absorção ótica para a clorofila $b$

\subsection{3- Isolamento de cloroplastos}

Para o isolamento de cloroplastos, cerca de 10 gramas de folhas foram lavadas com uma solução aquosa de $0,1 \%$ de Tween 20 . Todos os passos subsequentes foram realizados à $4^{\circ} \mathrm{C}$. As folhas foram colocadas em um liquidificador contendo $100 \mathrm{~mL}$ de tampão de homogenização $[0,33 \mathrm{M}$ de sacarose, $50 \mathrm{mM}$ de Tris-Cl pH 8,0, 0,2\% (p/v) de BSA, 0,04\% (v/v) de $\beta$ mercaptoetanol e $0,2 \%(p / v)$ de PVP (polivinilpirrolidona) insolúvel] e 3 a 5 pulsos foram efetuados para o completo rompimento celular. $O$ homogenizado foi filtrado utilizando-se 2 camadas de papel Miracloth e duas frações de $1 \mathrm{~mL}$ foram recolhidas em tubos Eppendorf. Um dos tubos foi mantido no gelo [homogenizado $(H)$ ] e o outro centrifugado por 5 minutos a $13.000 \mathrm{rpm}$ (microcentrifuga). Deste último, separa-se o precipitado $(P)$ e o sobrenadante citossólico (S) em outros tubos Eppendorfs. O restante do homogenizado filtrado foi centrifugado ( 3 minutos, $3.500 \mathrm{rpm}$, rotor Sorvall ST-micro). O sobrenadante foi eliminado e o precipitado ressuspendido em $2 \mathrm{~mL}$ de tampão de suspensão [0,4M de manitol, $10 \mathrm{mM}$ de $\mathrm{KH} 2 \mathrm{PO} 4 \mathrm{pH} 7,2,0,2 \%(\mathrm{p} / \mathrm{v}) \mathrm{BSA}]$. Essa amostra foi adicionada sobre dois gradientes de Percoll contidos em um tubo "corex" [ $4 \mathrm{~mL}$ de Percoll $80 \%$ (v/v), 0,25M de sacarose e 4,8mL de Percoll $40 \%(\mathrm{v} / \mathrm{V}), 0,25 \mathrm{M}$ de sacarose]. 0 tubo corex foi centrifugado por 10 minutos, 10.000rpm, rotor HL-50T da Sorvall. Após a centrifugação, a fração enriquecida 
de cloroplastos foi coletada na interface das camadas de Percoll e diluídos em tampão de suspensão sem BSA. Centrifugou-se por 3 minutos a 3500 rpm no rotor HL-50T. O sobrenadante foi descartado e o precipitado ressuspendido em $1 \mathrm{~mL}$ de tampão de suspensão sem BSA. Essa etapa foi repetida várias vezes para eliminação do Percoll. O precipitado final foi ressuspendido em $100 \mu \mathrm{L}$ de tampão de suspensão sem BSA. Esse isolamento de cloroplastos foi adaptado de Bartlet et al. (1982), Pilon et al. (1992) e Silva-Filho et al. (1997).

\subsection{4- Extração das enzimas envolvidas no estresse oxidativo}

Folhas de planta de fumo transgênica e selvagem foram usadas para as análises enzimáticas. A metodologia usada foi baseada em protocolo estabelecido por Azevedo et al. (1998). As extrações foram efetuadas à $4^{\circ} \mathrm{C}$. Cinco a dez gramas de folhas foram homogenizadas em $10 \mathrm{~mL}$ de uma solução tampão fosfato de potássio $100 \mathrm{mM}(\mathrm{pH} 7,5)$, contendo $1 \mathrm{mM}$ de EDTA, 3mM de DTT, e 4\% (p/v) de PVP insolúvel. O homogenizado foi centrifugado a $17.000 \mathrm{Xg}$ durante 30 minutos. $O$ sobrenadante foi coletado e as alíquotas armazenadas a $-80^{\circ} \mathrm{C}$ para as determinações de atividades.

\subsection{5- Determinação das atividades totais da catalase (CAT), glutationa redutase (GR) e superóxido dismutase (SOD)}

A atividade de CAT foi determinada conforme descrito por Kraus et al. (1995) com algumas modificações. A atividade CAT foi feita monitorando-se em um espectrofotômetro à $25^{\circ} \mathrm{C}$ uma mistura contendo $1 \mathrm{~mL}$ de solução tampão fosfato de potássio $100 \mathrm{mM}(\mathrm{pH} 7,5)$, contendo $2,5 \mu \mathrm{L}$ de $\mathrm{H}_{2} \mathrm{O}_{2}(30 \%)$ preparado imediatamente antes do uso. A reação foi iniciada adicionando-se $15 \mu \mathrm{L}$ de extrato de plantas (ítem 3.14) e a atividade determinada pela 
decomposição de $\mathrm{H}_{2} \mathrm{O}_{2}$ acompanhando a mudança de absorbância a $240 \mathrm{~nm}$ durante 2 minutos, contra uma prova em branco com $\mathrm{H}_{2} \mathrm{O}_{2}$ e sem extrato foliar.

A atividade de $G R$ foi determinada de acordo com metodologia de Smith et al. (1988) com pequenas alterações. A atividade $G R$ foi ensaiada num espectrofotômetro a $30^{\circ} \mathrm{C}$ numa mistura contendo $3 \mathrm{~mL}$ de uma solução tampão fosfato de potássio $100 \mathrm{mM}$ (pH 7,5), contendo $1 \mathrm{mM}$ de NADPH. A reação foi iniciada com a adição de 25 a $50 \mu \mathrm{L}$ do extrato da planta. A taxa de redução da glutationa oxidada foi monitorada via alteração da absorbância a $412 \mathrm{~nm}$ durante 2 minutos.

A atividade de SOD foi medida de acordo com metodologia de Steel \& Nair (1995) com pequenas alterações. A atividade foi monitorada em espectrofotômetro a $25^{\circ} \mathrm{C}$ numa mistura contendo uma solução tampão fosfato de potássio $100 \mathrm{mM}(\mathrm{pH} 7,8)$, contendo $0,5 \mathrm{mM}$ de xantina (dissolvida em $\mathrm{NaOH}$ puro) e $0,1 \mathrm{mM}$ de citocromo c. O ensaio controle foi iniciado pela adição de 0,04 unidades de xantina oxidase (Sigma) e a taxa de redução de citocromo c monitorada em $550 \mathrm{~nm}$ por 1 minuto. A atividade da SOD foi determinada pela inibição da taxa de redução do citocromo c pela adição de 10 a $50 \mu \mathrm{L}$ do extrato da planta. Uma unidade de atividade total da SOD é definida como sendo a quantidade de enzima que inibiu a taxa de redução de citocromo c em $50 \%$.

\subsection{1- Gel de atividade para SOD}

Amostras foliares ( $50 \mu \mathrm{g}$ de proteínas) foram aplicadas em géis não-desnaturantes (8\%) e a eletroforese conduzida a $4^{\circ} \mathrm{C}$ com corrente constante de $30 \mathrm{~mA} / \mathrm{gel}$.

Após a separação eletroforética, a atividade da SOD foi determinada como descrito por Beauchamp \& Fridovich (1971). O gel "PAGE" não denaturante foi lavado com água destilada-deionizada e incubado com $50 \mathrm{mM}$ de tampão fosfato de potássio $(\mathrm{pH} 7,8), 1 \mathrm{mM}$ de EDTA, $0,05 \mathrm{mM}$ de 
riboflavina, 0,1 mM de NBT e 0,3\% de N,N,N',N'-tetrametiletilenediamina por 30 minutos a temperatura ambiente (no escuro). No final deste período a reação foi paralisada lavando-se o gel com água destilada-deionizada. O gel foi, então, iluminado até o aparecimento de bandas incolores referentes a atividade da SOD.

Como um controle positivo, SOD bovina (Sigma Chemical Co.) foi aplicada em todos os géis.

\subsection{6- Determinação do peso seco}

Plântulas de fumo $R_{1}$ e $R_{2}$ germinadas em placas de petri contendo meio MS (Murashige e Skoog, 1962), MS sem sacarose e MS sem nitrogênio $\left(\mathrm{NH}_{4} \mathrm{NO}_{3}\right)$ foram avaliadas quanto aos teores de matéria seca aos 12 , 24 e 36 dias após a germinação. As placas de Petri foram mantidas em sala de crescimento sob condições de fotoperíodo de $16 / 8$ horas (claro/escuro), $25^{\circ} \mathrm{C}$, provida de lâmpadas fluorescentes que forneciam uma radiação fotossintetizante ativa de $\sim 150 \mu \mathrm{mol} . \mathrm{m}^{-2} . \mathrm{s}^{-1}$. As placas de petri contendo 50 sementes foram distribuidas em três blocos casualisados, com três repetições cada. As partes aéreas das plântulas foram excisadas e deixadas em estufa a uma temperatura constante de $80^{\circ} \mathrm{C}$ durante 24 horas. Em seguida, foram determinados os pesos secos das amostras. 


\section{4- RESULTADOS}

\section{1- Obtenção das plantas transgênicas}

Discos foliares de Nicotiana tabacum foram transformados via Agrobacterium tumefaciens sendo que várias plântulas foram regeneradas em meio contendo um agente seletivo (antibiótico kanamicina), sugerindo a origem a partir da transformação das células.

Posteriormente, as plântulas enraizadas, foram transferidas para vasos e aclimatadas em casa de vegetação, juntamente com plantas selvagens (WT) que serviram de controle.

\section{2- Análise das plantas transgênicas}

\subsection{1- Screening por PCR e Western Blotting}

Foram obtidas do processo de transformação e regeneração, 8 plantas provenientes da transformação com o plasmideo Bin2-35S/baE9' e 10 plantas da transformação com o plasmídeo Bin2-35SrbcS-IbaE9'.

A fim de detectar a presença do T-DNA nas plantas obtidas, procedeu-se a análise por PCR (Figura 5). Vários transformantes independentes analisados apresentaram o fragmento de DNA amplificado, correspondente ao gene da leghemoglobina, enquanto que o controle é desprovido do fragmento de DNA. 


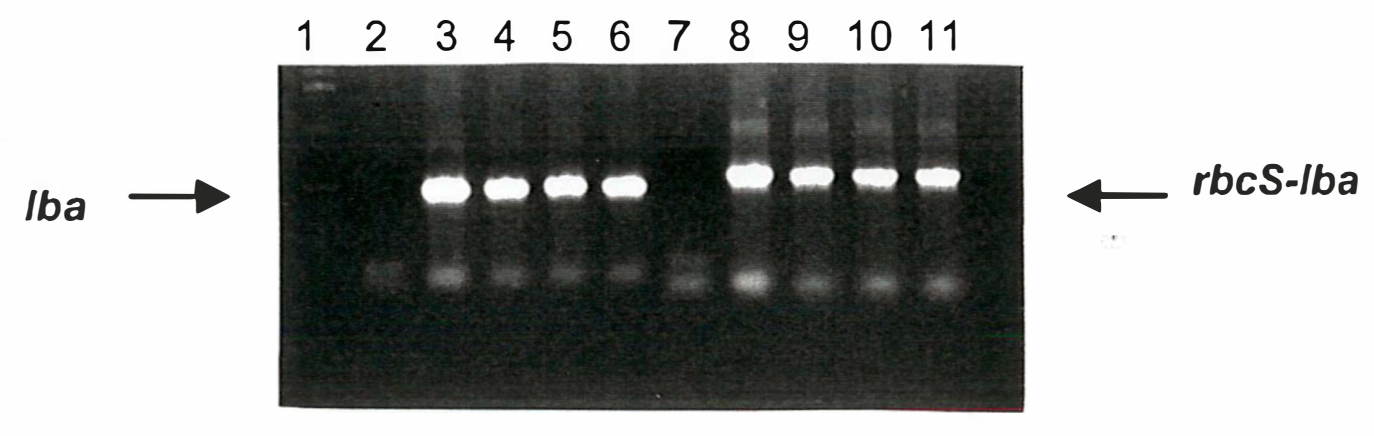

Figura 5: "Screening" por PCR das plantas parentais regeneradas obtidas da transformação via $A$. tumefaciens.

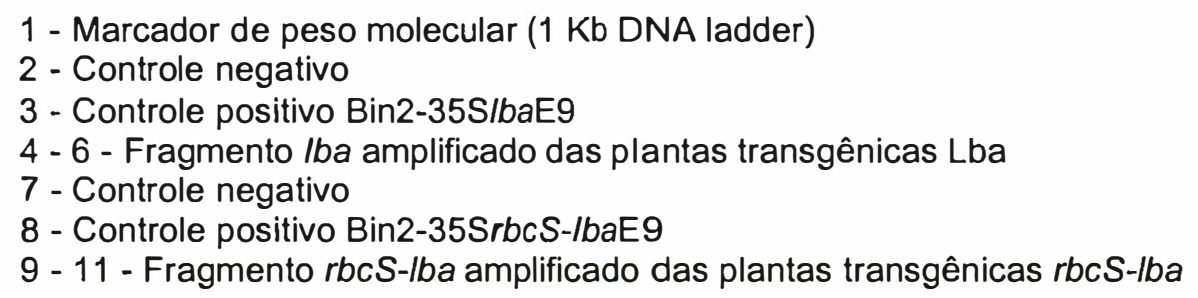

A confirmação do fragmento de DNA correspondente ao gene da leghemoglobina não assegura que o gene seja transcrito, uma vez que o T-DNA pode inserir-se em regiões de heterocromatina. Como forma de verificar a presença da proteina, 18 plantas transformadas foram analisadas por Western Blotting (Figura 6). Das 18 plantas que continham o T-DNA, apenas 11 expressaram o gene Iba. Destas, 5 eram transformadas com o plasmídeo Bin35SIbaE9' (L4, L5, L6, L7 e L8) e 6 transformadas com o plasmídeo Bin235SrbcS-IbaE9' (R2, R3, R6, R7, R9 e R10).

A imunodetecção revelou a presença de uma banda de aproximadamente $16 \mathrm{kDa}$ nas plantas Lba (leghemoglobina no citoplasma) e uma outra nas plantas rbcS-Iba (leghemoglobina nos cloroplastos) de peso molecular ligeiramente superior, ambas referentes à proteína Lba. A diferença existente entre os pesos moleculares das bandas é certamente devida a existência de 5 resíduos de amino ácidos correspondentes à região de ligação entre a sequência de direcionamento cloroplástica e a proteína Lba. 
$16 \mathrm{kDa}$

Figura 6: Western Blotting (amostra representativa) mostrando a presença da leghemoglobina nos transformantes primários $\left(R_{0}\right)$

1 - Marcador de peso molecular SDS-PAGE

2 - Controle Positivo (leghemoglobina do nódulo de soja)

4 e 5 - Plantas trangênicas $l b a$

6 - Controle negativo (Planta WT)

7 e 8 - Plantas transgênicas rbcS-lba

A ausência da sequência de direcionamento da Rubisco ( $r b c S)$ da proteina quimérica rbcS-Lba, sugere que a leghemoglobina foi importada e corretamente processada no interior dos cloroplastos. Entretanto, a imunodetecção em uma fração enriquecida de cloroplastos é um requerimento necessário.

As plantas expressando a leghemoglobina foram então autofecundadas produzindo a geração $R_{1}$. Foram obtidas cerca de 80 plantas transgênicas expressando a leghemoglobina. Destas, 30 apresentaram a proteína ligada à sequência de direcionamento para o cloroplasto (verificado por Screening por PCR e análise Western Blotting). 


\subsection{2- O peptídeo de trânsito da Rubisco direciona a leghemoglobina ao interior dos cloroplastos}

O fracionamento subcelular das plantas transgênicas foi realizado via centrifugação a fim de obter um sobrenadante citossólico e um precipitado organelar. A fração enriquecida em cloroplastos foi obtida por centrifugação diferencial e subsequente purificação das organelas em gradiente de Percoll. A fim de verificar a localização subcelular da Lba foi realizado um ensaio de imunodetecção com as frações enriquecidas em cloroplastos e um homogenizado total (Figura 7).

\begin{tabular}{|c|c|c|c|c|c|c|c|c|}
\cline { 2 - 9 } \multicolumn{1}{c|}{} & 1 & 2 & 3 & 4 & 5 & 6 & 7 & 8 \\
\cline { 2 - 9 } \multicolumn{1}{c|}{} & Lba & & \multicolumn{2}{|c|}{ WT } & \multicolumn{2}{|c|}{ Lba } & \multicolumn{2}{|c|}{ rbcS-Lba } \\
\hline MW & & & H & C & H & C & H & C \\
\hline \multirow{1}{*}{$16 \mathrm{kDa} \rightarrow$}
\end{tabular}

Figura 7 : Imunodetecção da leghemoglobina nas frações subcelulares das plantas de tabaco transgênicas. A análise Western Blotting foi realizada com $10 \mu \mathrm{g}$ de proteínas do homogenizado $(H)$ e da fração enriquecida de cloroplastos (C). Um extrato proteico de leghemoglobina de soja $(0,1 \mu \mathrm{g})$ foi utilizado como controle (canaleta 1). A massa molecular $(\mathrm{kDa})$ está indicada.

Análises de Western Blotting em plantas transformadas com a construção rbcS-Iba mostraram que a leghemoglobina foi corretamente direcionada aos cloroplastos. O enriquecimento da Lba na fração enriquecida por cloroplastos foi relativamente baixa, mas isto é esperado uma vez que as proteínas cloroplásticas do mesófilo foliar representam $50 \%$ da proteína total 
das folhas. Portanto, o máximo enriquecimento só pode ser de 2 vezes (SilvaFilho et al., 1997). Por outro lado, as plantas transformadas com o gene desprovido da sequência de direcionamento rbcS, expressaram a Lba apenas no citosol. Como esperado, o tamanho da Lba madura observado para rbcS-lba no interior dos cloroplastos foi superior ao encontrado para a Lba sem a sequência de direcionamento. Esta diferença é devido a presença de 5 aminoácidos da região "linker".

A fim de verificar se a presença da leghemoglobina no interior dos cloroplastos estava interferindo na relação $\mathrm{CO}_{2} / \mathrm{O}_{2}$, e alterando o metabolismo aeróbico, vários experimentos foram realizados com as plantas das linhagens autofecundadas $\left(R_{1}\right.$ e $\left.R_{2}\right)$.

\subsection{3- Determinação do conteúdo de clorofila $a$ e $b$ das plantas transgênicas}

O teor de oxigênio em uma célula vegetal afeta inúmeros processos fisiológicos, dentre os quais convém ressaltar a sintese de clorofila. (Figura 8)

Para determinar o conteúdo de clorofila $a$ e $b$, plantas da geração $R_{1}$ da linhagem rbcS e selvagem foram utilizadas. Nessa primeira análise as plantas transgênicas não apresentaram aumento no teor de clorofila $b$ (não mostrados). Este resultado não está de acordo com os dados observados por Holmberg et al. (1997), no qual a planta de fumo transgênica expressando uma hemoglobina bacteriana no citossol apresentaram niveis superiores de clorofila $b$ em relação ao controle.

Com relação ao nível de clorofila $a$, também não foram reveladas diferenças significativas. Entretanto, deve-se considerar estes resultados com precaução, uma vez que apenas um pequeno número de plantas foi analisado $\mathrm{e}$ o número de repetições não foi adequado. Apesar do número de plantas analisadas ser muito pequeno para detectar diferenças significativas e tirar 
dados conclusivos, o experimento serviu para otimizar a técnica para, posteriormente, ser utilizada nas plantas da geração $R_{2}$.

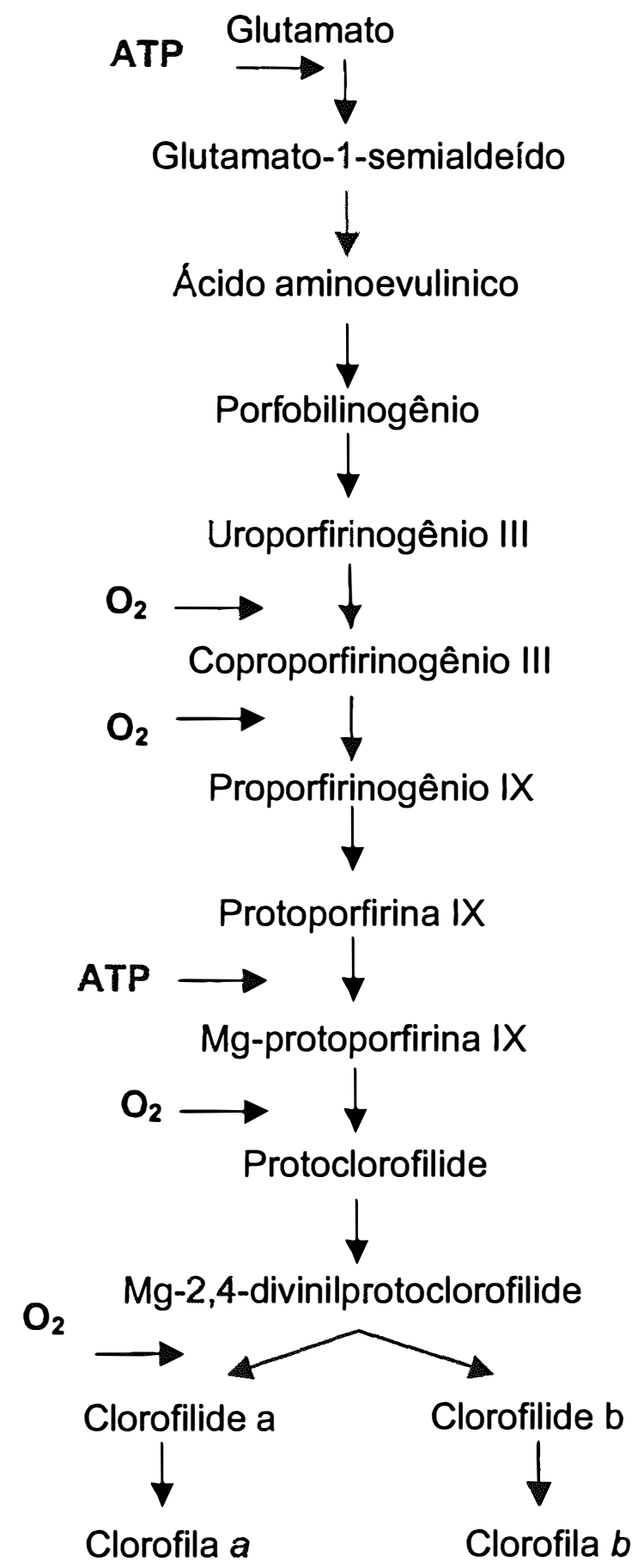

Figura 8: Passos dependentes de $\mathrm{O}_{2}$ na biossíntese das clorofilas $a$ e $b$ (adaptado de Holmberg et al., 1997). 
Após a obtenção da geração $R_{\mathbf{2}}$, as plantas foram analisadas novamente quanto aos teores de clorofila $a$ e $b$ (Figura 9). Confirmando os resultados obtidos anteriormente na geração $R_{1}$, pode-se constatar que as plantas transgênicas expressando a leghemoglobina nos cloroplastos, não apresentam alteração nos níveis de clorofila, sugerindo que o processo de biossintese de clorofila não é afetado pela presença da leghemoglobina.

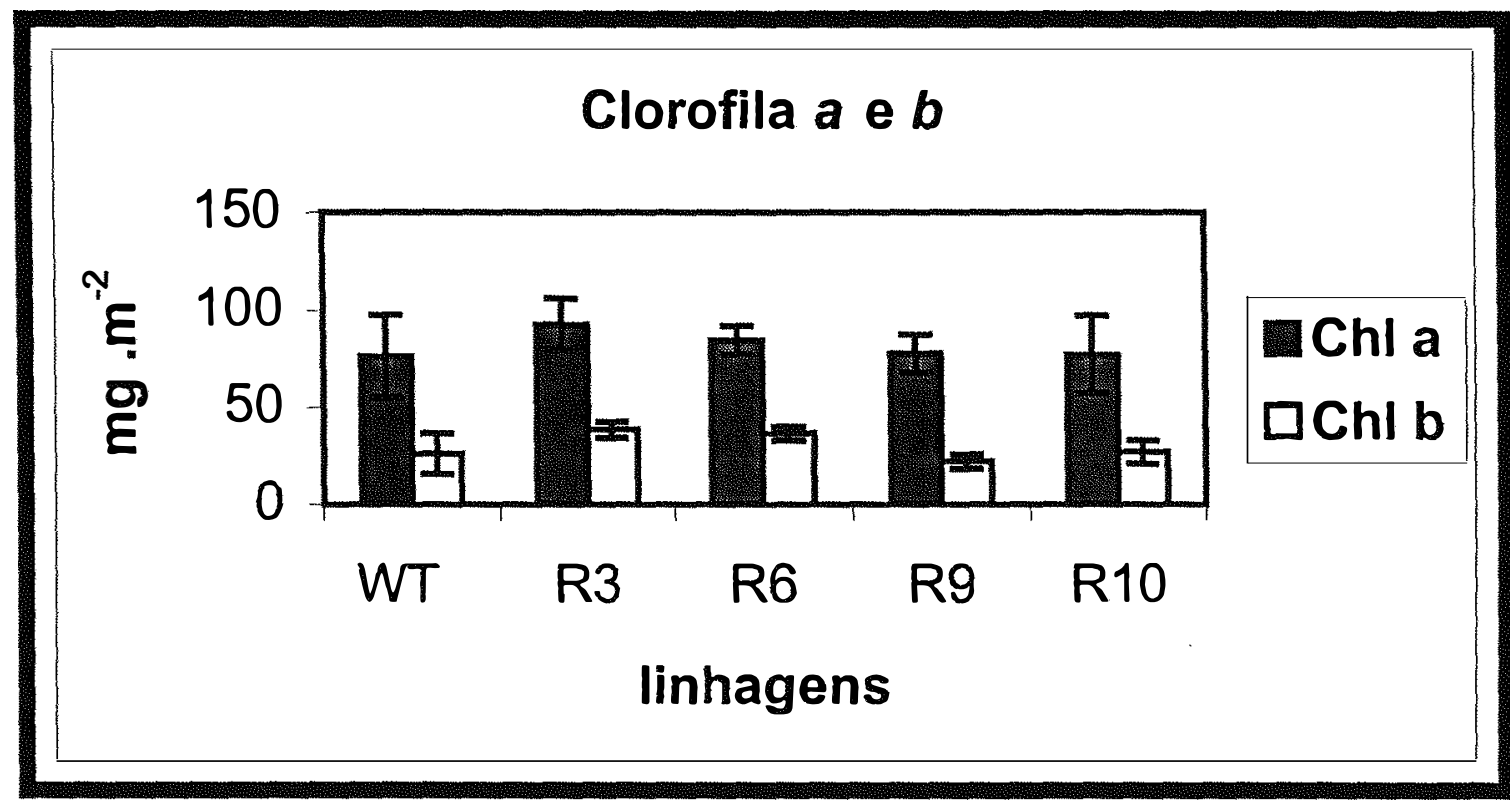

Figura 9: Quantificação de Clorofila a e $b$ (expressadas em $\mathrm{mg}$ de clorofila. $\mathrm{m}^{-2}$ ) em discos foliares de linhagens transgênicas e tipo selvagem cultivados em casas de vegetação. As análise foram realizadas em um único período (12 h) e os valores representam média de 10 plantas \pm desvio padrão.

\subsection{4- Análise de peso seco nas plantas transgênicas}

Estima-se que aproximadamente $90 \%$ do peso seco das plantas é derivado da assimilação de $\mathrm{CO}_{2}$ pela Rubisco durante o processo fotossintético (Zelich, 1992). Desta forma, caso a leghemoglobina esteja realmente 
interferindo na relação $\mathrm{CO}_{2} / \mathrm{O}_{2}$ favorecendo o processo de carboxilação, as plantas transgênicas devem apresentar uma maior quantidade de matéria seca. Para verificar este parâmetro, sementes $R_{1}$ de transformantes independentes $e$ de um controle não transformado (WT) foram germinadas em meio de cultura MS sem kanamicina e o seu desenvolvimento foi acompanhado visualmente. $A$ coleta das plantas se deu em intervalos regulares aos 12, 24 e 36 dias após a germinação. A germinação das plantas ocorreu de forma homogênea, contrariamente aos resultados obtidos por Holmberg et al. (1997) que verificaram que plantas de fumo expressando uma hemoglobina bacteriana no citossol apresentaram uma germinação mais rápida em relação ao controle. $A$ análise do teor de matéria seca revelou um aumento médio de $50 \%$ nas plantas transgênicas em relação ao controle (dados não apresentados), entretanto, devido à grande variação existente entre os dados obtidos, refletido em um alto desvio padrão, a análise estatística (Análise de Variância) mostrou não haver diferenças significativas entre os tratamentos. Esta variação era esperada devido as plantas pertencerem à geração $R_{1}$. Ou seja, trata-se de uma população segregante apresentando $25 \%$ de plantas homozigóticas $\left(\mathrm{Lb}^{+} / \mathrm{Lb}^{+}\right)$, $50 \%$ de plantas heterozigóticas $\left(\mathrm{Lb}^{+} / \mathrm{Lb}^{-}\right)$e $25 \%$ de plantas selvagens ( $\left.\mathrm{Lb}^{-} / \mathrm{Lb}^{-}\right)$. Para contornar esse fato, esse experimento foi repetido várias vezes com plantas da geração $R_{2}$. Novamente, confirmando os resultados obtidos anteriormente, a análise estatística não mostrou significância entre os peso secos obtidos, apesar de haver algumas diferenças, como pode ser observado na (Figura 10). 


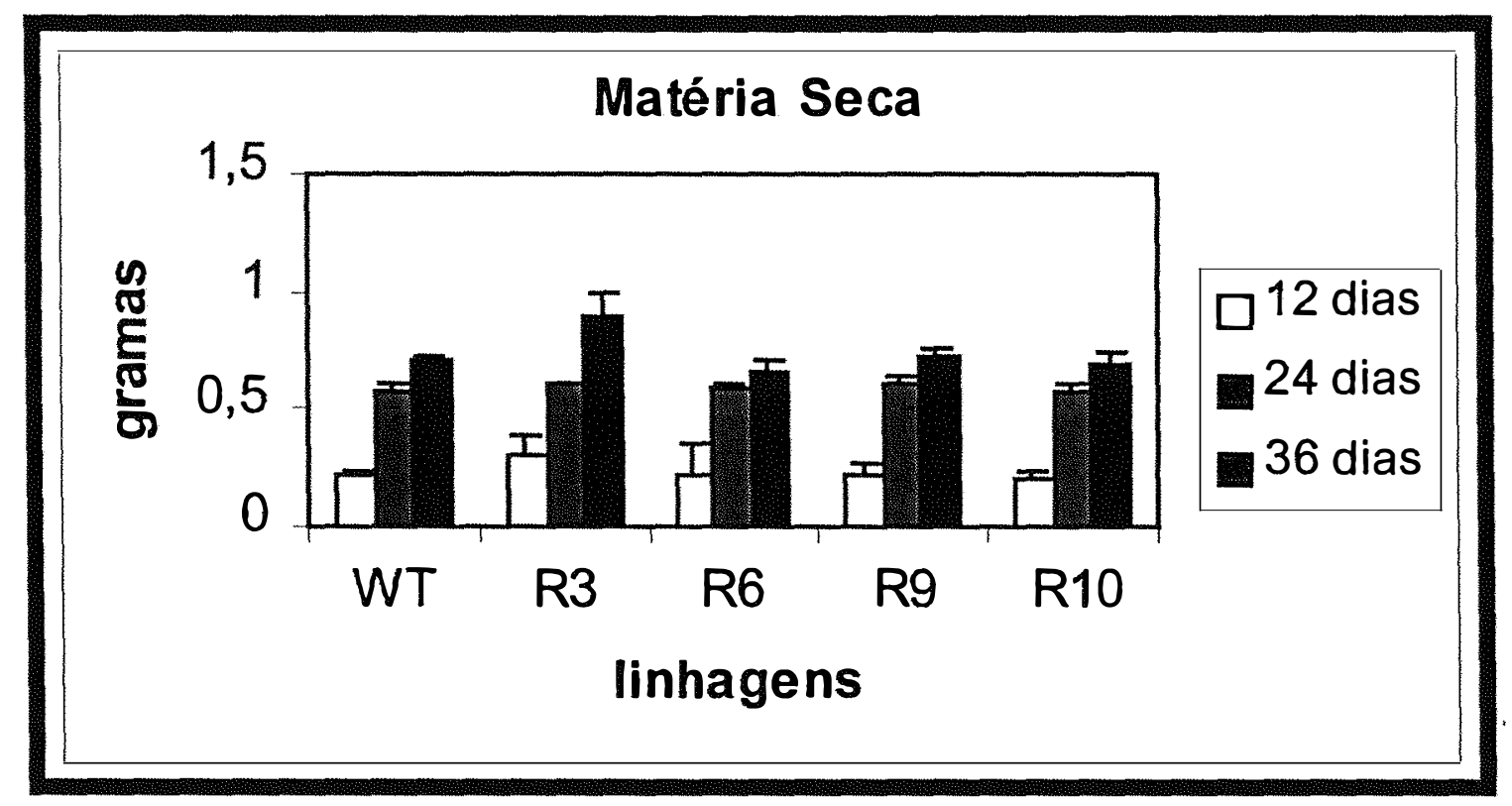

Figura 10: Evolução do conteúdo de matéria seca entre plantas rbcS-Lba e WT. As medidas do peso seco foram realizadas em intervalos regulares $(12,24$ e 36 dias) a partir de plantas $R_{2}$ cultivadas em meio MS normal. Os resultados apresentados são médias de 10 plantas de cada transformante independente rbcS-Lba (com 3 repetições/cada) e do controle (WT, 3 repetições).

A fim de complementar os dados obtidos no experimento anterior, o mesmo ensaio foi realizado retirando-se a fonte de carbono (sacarose) do meio MS (Figura 11). Caso as plantas transformadas apresentem uma menor atividade fotorrespiratória, elas devem produzir maiores teores de biomassa devido à uma maior produção de carboidratos, via aumento da fotossíntese, para serem utilizados como fonte de carbono. 


\section{Matéria Seca}

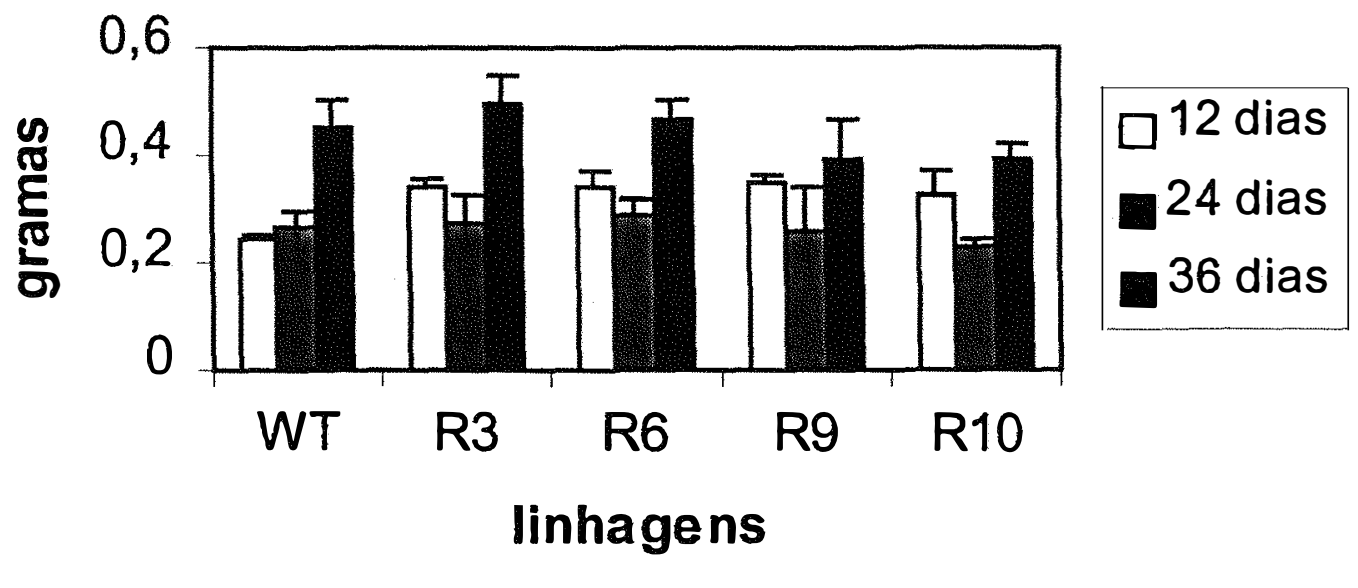

Figura 11: Evolução de matéria seca entre plantas rbcS-Lba e WT. As medidas do peso seco foram realizadas em intervalos regulares (12, 24 e 36 dias) a partir de plantas $R_{2}$ cultivadas em meio MS sem sacarose. Os resultados apresentados são médias de 10 plantas de cada transformante independente rbcS-Lba (com 3 repetições/cada) e do controle (WT, 3 repetições).

A análise de variância constatou que não havia diferença significativa entre os tratamentos, com exceção dos primeiros 12 dias. Entretanto, esta diferença observada não deve estar associada à presença da leghemoglobina pois as plantas transgênicas mostram, ao contrário do esperado, um menor conteúdo de biomassa. Esta observação provavelmente deve estar associada à uma maior quantidade de tecido de reserva presente nas sementes das plantas controle, já que ocorreu apenas nos estágios imediatamente posteriores à germinação.

No ciclo fotorrespiratório, além da perda de $\mathrm{CO}_{2}$, há também liberação de $\mathrm{NH}_{3}$. Essa amônia deve ser rapidamente reassimilada pelo sistema 
glutamina sintetase/glutamato sintase (GS/GOGAT). Segundo Lea \& Leegood (1995), a taxa de reassimilação fotorrespiratória é muito superior à da assimilação primária que envolve a redução do nitrato. De acordo com os autores, o ciclo do nitrogênio fotorrespiratório pode ser considerado como o principal mecanismo do metabolismo do nitrogênio nas folhas das plantas $C_{3}$. Assim, a fim de verificar indiretamente um possivel aumento da taxa de carboxilação nas plantas transgênicas, foram realizados experimentos visando analisar o conteúdo de matéria seca das plantas germinadas em meio MS sem uma das fontes de nitrogênio $\left(\mathrm{NH}_{4} \mathrm{NO}_{3}\right)$ (Figura 12).

Os resultados indicam que nenhuma das linhagens apresentou diferença significativa quanto ao teor de matéria seca, reforçando os dadoș anteriores.

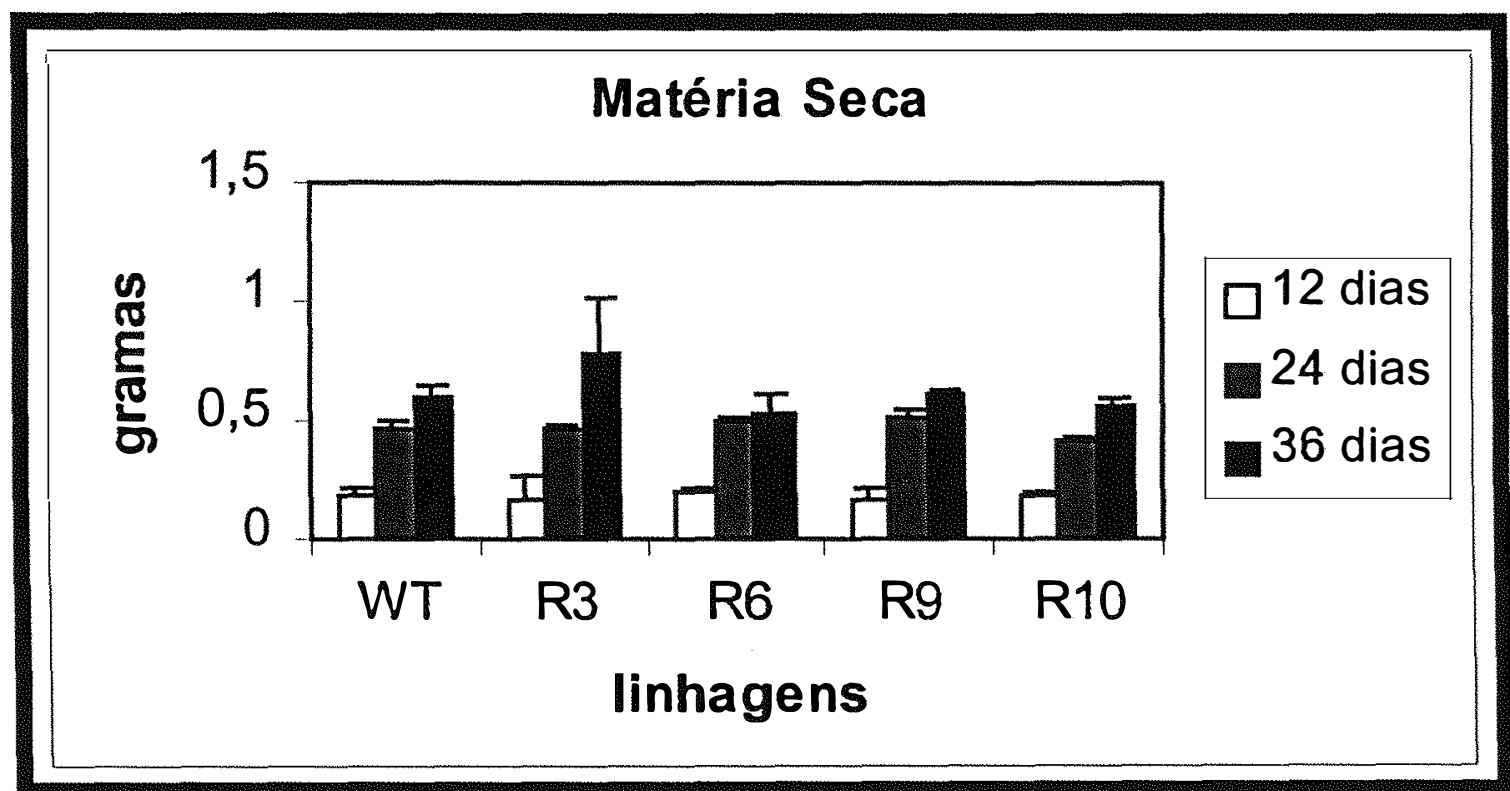

Figura 12: Evolução de matéria seca entre plantas rbcS-Lba e WT. As medidas do peso seco foram realizadas em intervalos regulares (12, 24 e 36 dias) a partir de plantas $R_{\mathbf{2}}$ cultivadas em meio MS sem uma das fontes de nitrogênio $\left(\mathrm{NH}_{4} \mathrm{NO}_{3}\right)$. Os resultados apresentados são médias de 10 plantas de cada transformante independente rbcS-Lba (com 3 repetições/cada) e do controle (WT, 3 repetições). 


\subsection{5- Análise do teor de sacarose e amido}

A fixação do $\mathrm{CO}_{2}$ atmosférico via reações do ciclo de Calvin leva à formação de açúcares no estroma dos cloroplastos. Em folhas jovens, grande parte dos açúcares formados permanecem nos locais de síntese para formação de novos compostos celulares. Entretanto, em folhas maduras ocorre uma exportação de sacarose à outros tecidos ou órgãos da planta (Kaiser \& Heber, 1984). Quando a taxa de fotossíntese excede a taxa de exportação de sacarose, esta acumula-se nas folhas.Portanto, o metabolismo da sacarose e do amido são diretamente associados à assimilação do carbono fotossintético. Plantas rbcS-lba e o controle foram cultivadas em casa de vegetação e acompanhadas visualmente de forma a monitorar as taxas de crescimento.

Amostras de folhas jovens (a segunda folha a partir do ápice), com três repetições para cada um dos quatro transformantes independentes da geração $R_{1}$, foram analisadas.

O conteúdo médio de sacarose das plantas rbcS-lba foi bastante superior ao encontrado no controle (dados não mostrados). Entretanto, os niveis de amido não foram significativamente diferentes. $O$ aumento no teor de sacarose fez com que o teor de carboidratos totais (sacarose + amido) fosse, em média, cerca de $15 \%$ superior. Esses dados indicaram uma alteração na taxa fotossintética possívelmente ocasionada pela alteração na relação $\mathrm{CO}_{2} / \mathrm{O}_{2}$ no interior dos cloroplastos. Como a maior parte dos carboidratos produzidos na fotossíntese destina-se à produção de fitomassa, esses dados contrastam com os resultados obtidos anteriormente na análise de matéria seca. Caso as plantas transgênicas apresentem uma maior quantidade de carboidratos totais, necessariamente devem apresentar um maior conteúdo de matéria seca. Entretanto, estes resultados devem ser tomados com precaução, pois o número de plantas analisados, por se tratar de um experimento de padronização de protocolo, foi muito pequeno. Neste sentido, novos experimentos foram delineados utilizando-se plantas da geração $R_{2}$ e com um número de repetições 
" $n$ " mais adequado. Para acompanhar a evolução de formação desses carboidratos durante o dia, duas amostras foram retiradas. Uma no período da manhã (7-8 horas) e a outra no final da tarde (6-7 horas).

Com relação ao teor de sacarose (Figura 13), pode-se notar estatisticamente que as plantas transformadas não diferenciam-se das plantas controle em nenhum dos períodos analisados. O mesmo aconteceu com o conteúdo de amido (Figura 14).

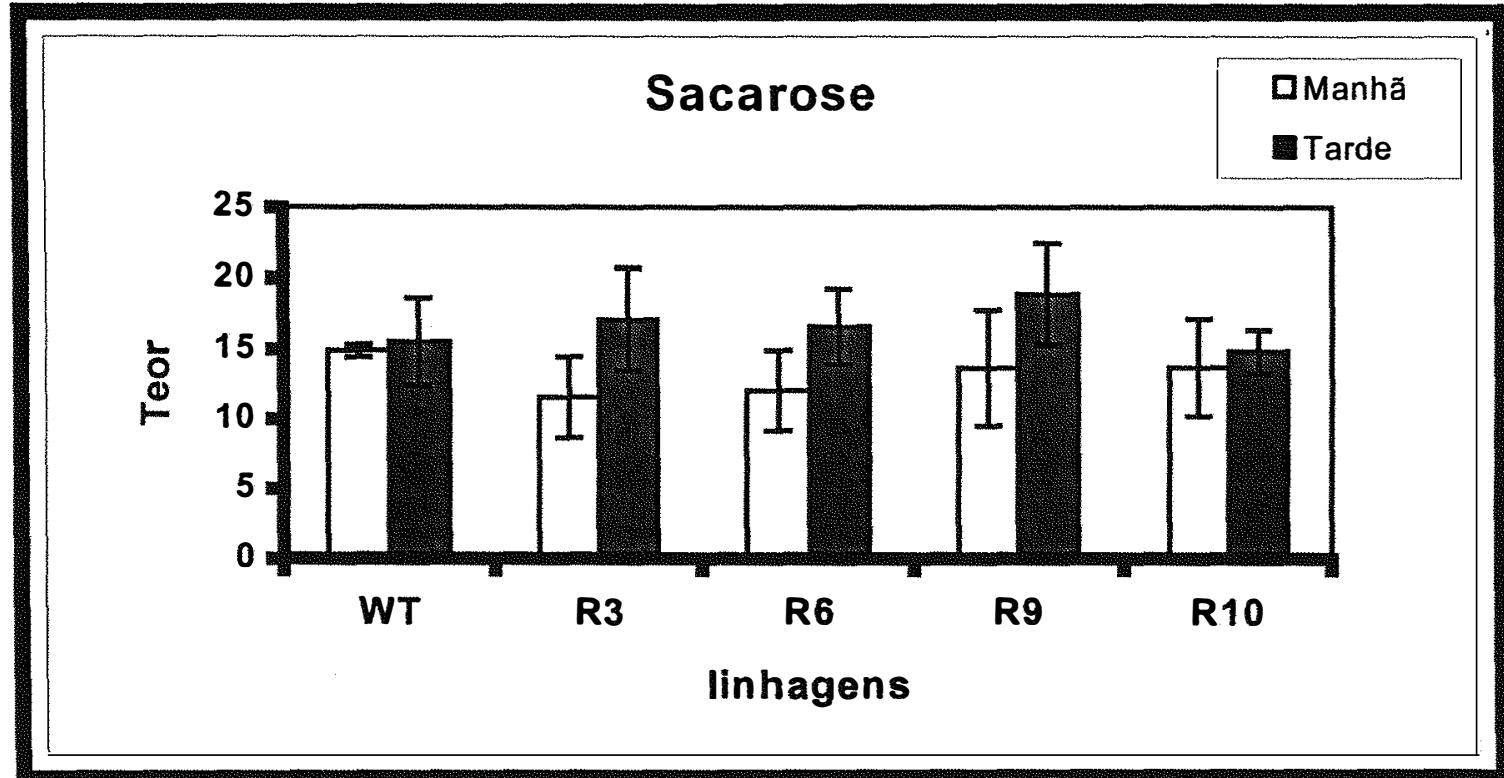

Figura 13:. Quantificação dos conteúdo de sacarose (expressado em $\mu \mathrm{mol}$ hexose equiv. $\mathrm{mg}^{-1} \mathrm{Chl}$ ). em discos foliares de tabaco transgênicos e selvagem cultivados em casas de vegetação. As análises foram realizadas em dois períodos distintos: manhã $(7-8 \mathrm{~h})$ e tarde $(6-7 \mathrm{~h})$. Os valores representam médias de 10 plantas \pm desvio padrão. 


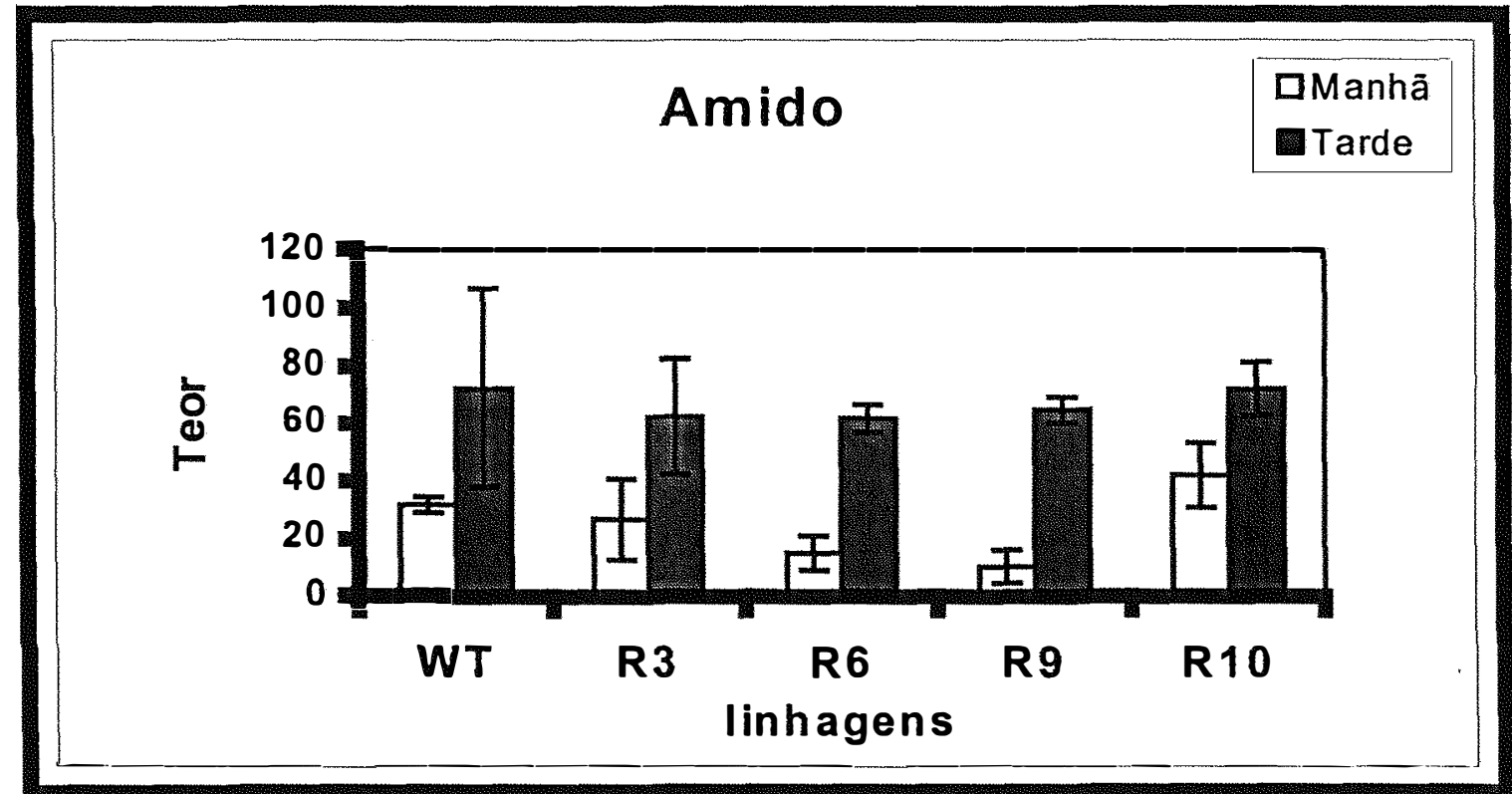

Figura 14:. Quantificação dos conteúdo de amido (expressado em $\mu \mathrm{mol}$ hexose equiv. $\mathrm{mg}^{-1} \mathrm{Chl}$ ). em discos foliares de tabaco transgênicos $\mathrm{e}$ selvagem cultivados em casas de vegetação. As análises foram realizadas em dois períodos distintos: manhã $(7-8 \mathrm{~h})$ e tarde $(6-7 \mathrm{~h})$. Os valores representam médias de 10 plantas \pm desvio padrão.

Os resultados observados indicam que não houve alterações nos niveis de sacarose e amido das plantas rbcS-Lba quando comparados ao controle.

4.2.6- Análise da atividade da catalase, glutationa redutase e superóxido dismutase

\subsubsection{1- Catalase (CAT)}

Durante o processo de oxidação do glicolato são produzidas grandes quantidades de peróxido de hidrogênio que são altamente tóxicos. 
Assim, as células desenvolveram sistemas de decomposição de $\mathrm{H}_{2} \mathrm{O}_{2}$ em $\mathrm{H}_{2} \mathrm{O}$ $\mathrm{e}_{2}$ via ação de enzimas como a catalase (CAT). Uma forma indireta de acompanhar a redução na atividade fotorrespiratória é verificar a diminuição da atividade da catalase. Se a concentração de oxigênio no interior dos cloroplastos estivesse sendo reduzida pela presença da leghemoglobina, o ambiente próximo ao sítio ativo da Rubisco estaria sendo modificado em favor da reação de carboxilação e as plantas transgênicas deveriam apresentar um menor nivel de atividade CAT. A fim de medir a atividade dessa enzima nas plantas transformadas, amostras foliares de 4 transformantes independentes da geração $R_{1}$ (rbcS-lba) foram coletadas em dois periodos distintos: 1) antes do florescimento (plantas com aproximadamente 8 semanas) e 2) no início do florescimento (plantas com aprox. 12 semanas). As amostras foram coletadas no período onde as plantas $\mathrm{C}_{3}$ apresentam uma maior taxa fotorrespiratória (1213 horas).

Observando-se os dois períodos analisados (dados não mostrados), verificou-se que em relação ao controle, todas as plantas transgênicas apresentaram uma diminuição na atividade CAT. Observam-se reduções de até $70 \%$ na atividade desta enzima. Estes resultados indicaram de forma preliminar, que as plantas transgênicas apresentam uma redução da atividade oxigenase da Rubisco. Novamente, apesar das análises terem sido efetuadas numa etapa de padronização das metodologias, o número de plantas utilizadas foi reduzido $e$ as repetições não foram adequadamente dimensionadas. A fim de esclarecer os dados obtidos, um novo ensaio foi conduzido com a geração $R_{2}$ utilizando um maior número de plantas. As amostras foram coletadas no periodo que antecede 0 florescimento (aproximadamente 8 semanas). $A$ análise das plantas transgênicas expressando a Lba no interior dos cloroplastos mostra que não houve alteração na atividade da catalase quando comparadas com o controle (Figura 15). Novos experimentos foram conduzidos com plantas da geração $R_{2}$ e os resultados foram sempre coincidentes. 


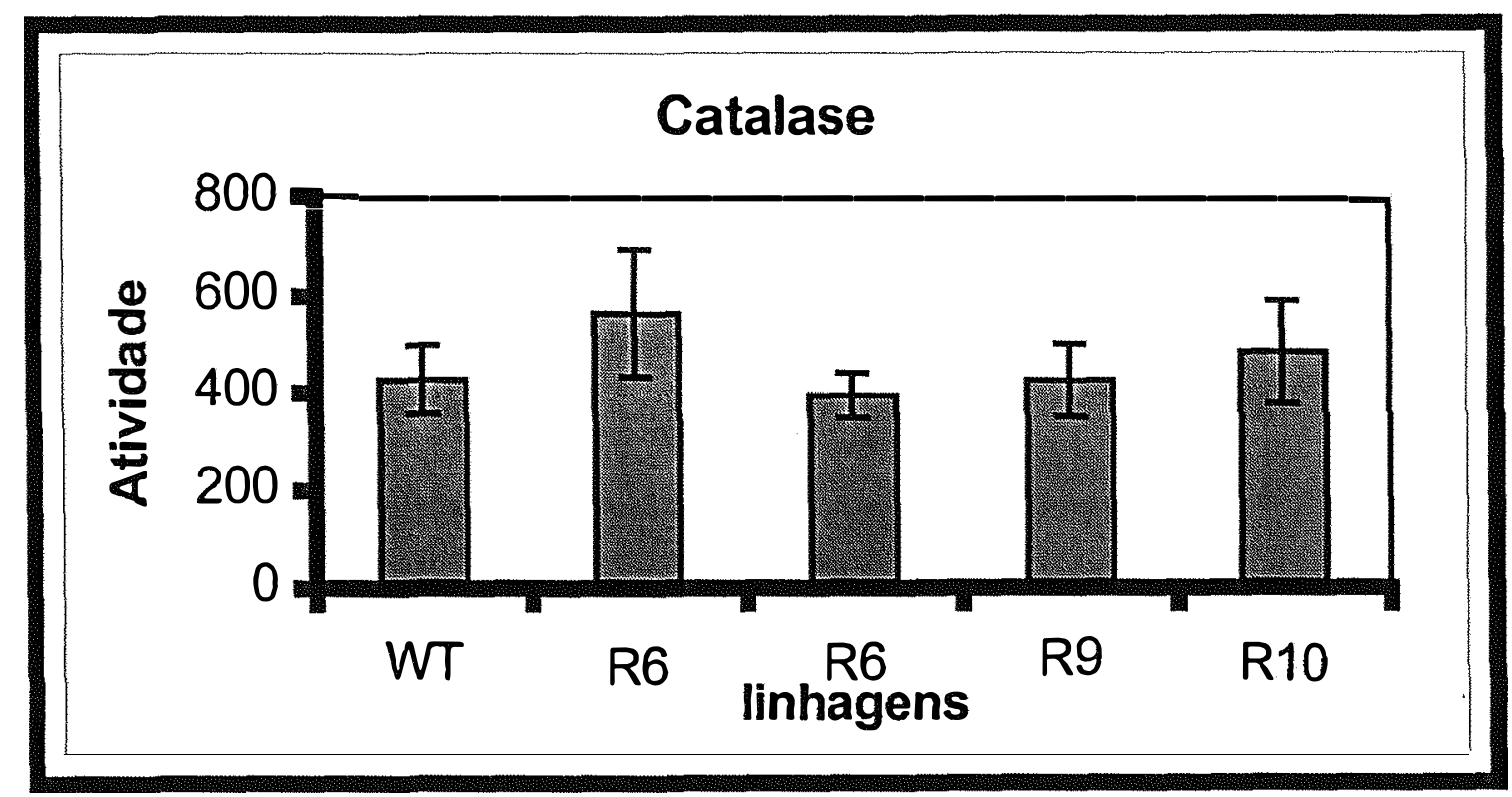

Figura 15: Atividade CAT ( $\mu \mathrm{mol} \cdot \mathrm{mg}^{-1}$. proteina $\mathrm{min}^{-1}$ ) nas folhas de plantas transgênicas e selvagens. As análises foram efetuadas em plantas de aproximadamente 8 semanas cultivadas em casa de vegetação (14/10 horas de fotoperiodo). Os dados representam a média de 10 plantas \pm desvio padrão.

\subsubsection{2- Glutationa Redutase (GR)}

Segundo Stitt (1991), um grande número de trabalhos têm mostrado que a sacarose sintetizada no citosol é exportada à partir dos cloroplastos na forma de triose fosfato. Quando o teor de sacarose atinge niveis elevados, verifica-se a inibição da fotossíntese devido à um processo de retroinibição que ocorre nas folhas (Herold, 1980). Todavia, como a planta continua exposta à alta luminosidade, rapidamente o fotossistema I (PSI) tornase reduzido. Este fato, faz com que o PSI, numa rota alternativa, doe elétrons às moléculas de oxigênio (reação de Mehler) convertendo-o em superóxido que posteriormente é convertido em peróxido pelas superóxidos dismutases. A 
produção de $\mathrm{H}_{2} \mathrm{O}_{2}$ ativa um sistema de decomposição do $\mathrm{H}_{2} \mathrm{O}_{2}$ em $\mathrm{H}_{2} \mathrm{O}$ e $\mathrm{O}_{2}$, via ascorbato peroxidade (APX) e GR. Assim, as linhagens tranformadas tenderiam a apresentar uma maior atividade total de GR caso estivessem com uma maior taxa de carboxilação da Rubisco.

A medida da atividade $G R$ foi efetuada nas plantas da geração $R_{1}$ nos mesmos extratos protéicos em que foram realizadas as atividades de catalase (CAT). Conforme os experimentos envolvendo a catalase (CAT), as plantas transgênicas apresentaram um aumento significativo na atividade de GR em duas linhagens (R3 e R6) em relação ao controle. Entretanto, ao proceder-se a análise em plantas da geração $R_{2}$, os resultados mostraram não haver diferenças entre as plantas transformadas e o controle (Figura 16).

\subsubsection{3- Superóxido Dismutase (SOD)}

Situações em que as plantas apresentam um excesso de poder redutor (NADPH e ATP), os elétrons são desviados às abundantes moléculas de oxigênio, via reação de Mehler, formando o radical superóxido. Esse radical rapidamente é convertido à peróxido de hidrogênio pelas Superóxidos Dismutases (SODs), presentes nos cloroplastos. Assim, espera-se que uma alteração do processo fotossintético, ocasione uma modificação na atividade e no padrão das isoformas dessa enzima.

A fim de complementar o estudo enzimático efetuado com as enzimas envolvidas no estresse oxidativo, experimentos envolvendo a atividade total e das isoformas da SOD foram realizados. Utilizando-se os mesmos extratos enzimáticos para estudar a atividade da CAT e GR nas plantas das gerações $R_{1}$ e $R_{2}$, foram retiradas alíquotas para os experimentos envolvendo a SOD. A análise da atividade total da SOD em duas gerações não mostrou nenhuma diferença significativa quando comparadas às plantas controle (Figura 17). 


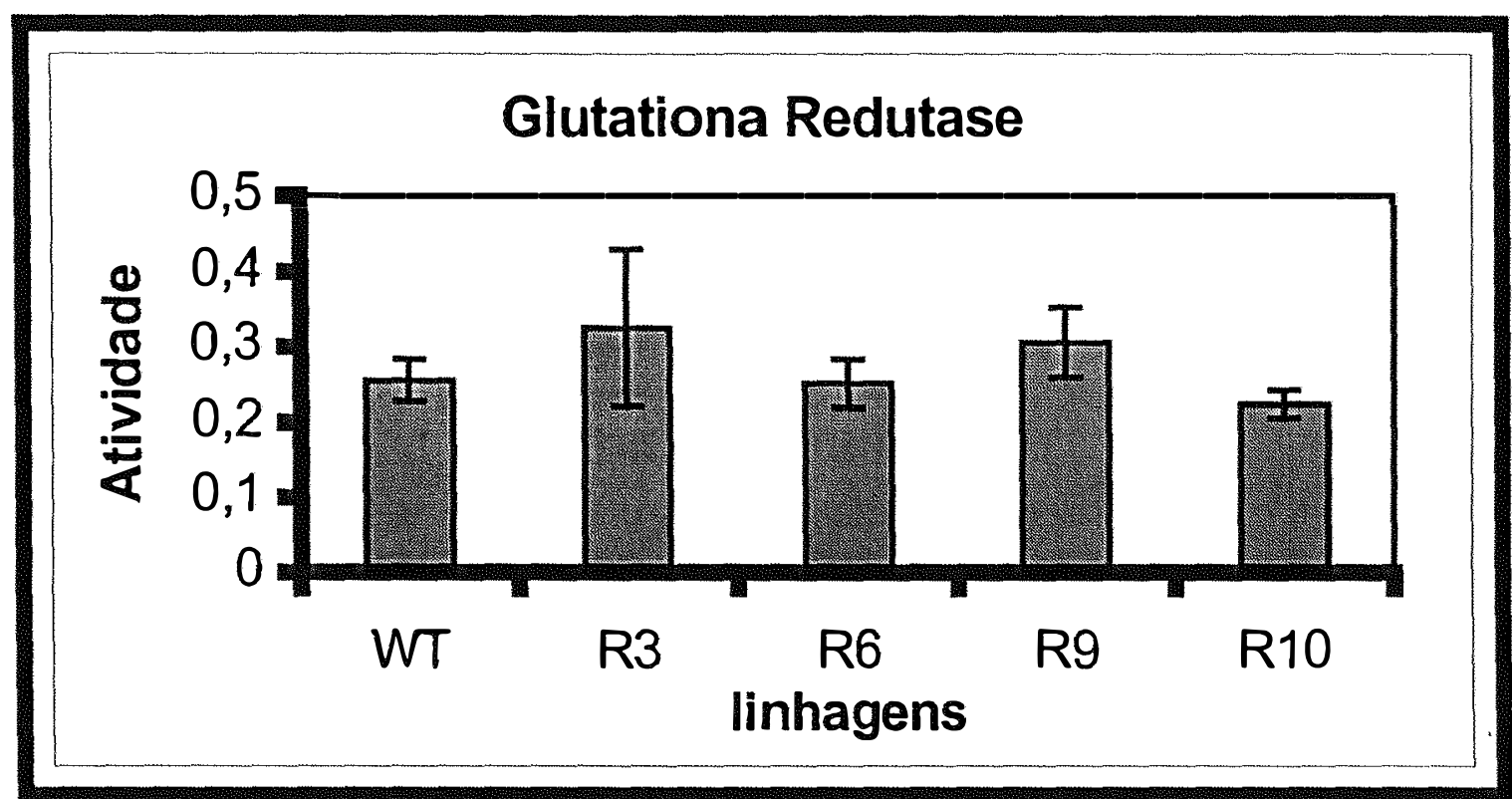

Figura 16: Gráfico mostrando a atividade GR $\left(\mu \mathrm{mol} . \mathrm{mg}^{-1}\right.$ proteina. $\left.\mathrm{min}^{-1}\right)$ nas folhas de plantas transgênicas e selvagens. As análises foram efetuadas em plantas de aproximadamente 8 semanas cultivadas em casa de vegetação (14/10 $\mathrm{h}$ de fotoperíodo). Os dados representam a média de 10 plantas \pm desvio padrão.

O padrão das isoformas das superóxidos dismutases também não foi alterado entre as plantas transformadas e o controle (Figura 18b). Quatro bandas referentes a isoenzimas da SOD foram claramente observadas em folhas (Figura 18a). As bandas foram numeradas de acordo com sua eletronegatividade ( $I=$ banda menos eletronegativa).

O padrão enzimático observado foi similar ao relatado por Van Camp et al. (1994). Contudo, as bandas referentes a SOD-Mn (inibida por $\mathrm{H}_{2} \mathrm{O}_{2}$ mas não por KCN) não foram detectadas nos experimentos, mesmo utilizandose altas concentrações de proteínas. Entretanto, comparando-se com o 


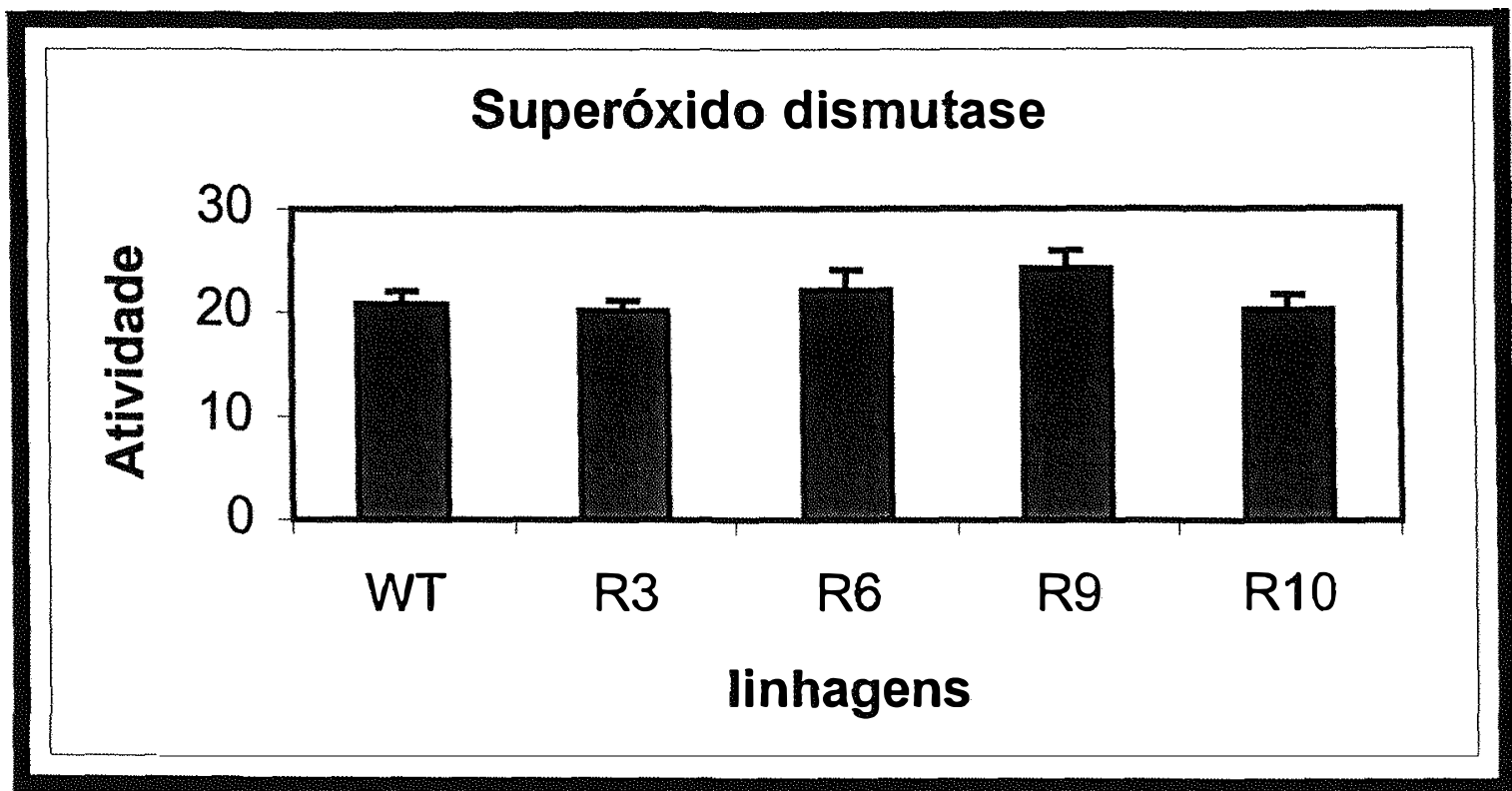

Figura 17: Atividade SOD ( $\mu \mathrm{mol} \cdot \mathrm{mg}^{-1}$ proteina. $\mathrm{min}^{-1}$ ) nas folhas de plantas transgênicas e selvagens (WT). As análises foram efetuadas em plantas de aproximadamente 8 semanas cultivadas em casa de vegetação (14/10 h de fotoperiodo). Os dados representam a média de 10 plantas \pm desvio padrão.

bandeamento eletroforético da SOD para tabaco já estabelecidos (Van Camp, 1994; Azevedo et al., 1998), pode-se assumir que a banda I é a SOD-Fe (resistente a inibição causada por $\mathrm{KCN}$ e $\mathrm{H}_{2} \mathrm{O}_{2}$ ). As bandas II, III e IV foram classificadas como SOD-Cu/Zn (inibidas por $\mathrm{KCN}$ e $\mathrm{H}_{2} \mathrm{O}_{2}$ ), sendo que as bandas II e III representam duas isoformas da SODCu/Zn citoplasmática. A banda IV representa a isoforma da SOD-Cu/Zn localizada no cloroplasto. 
a)

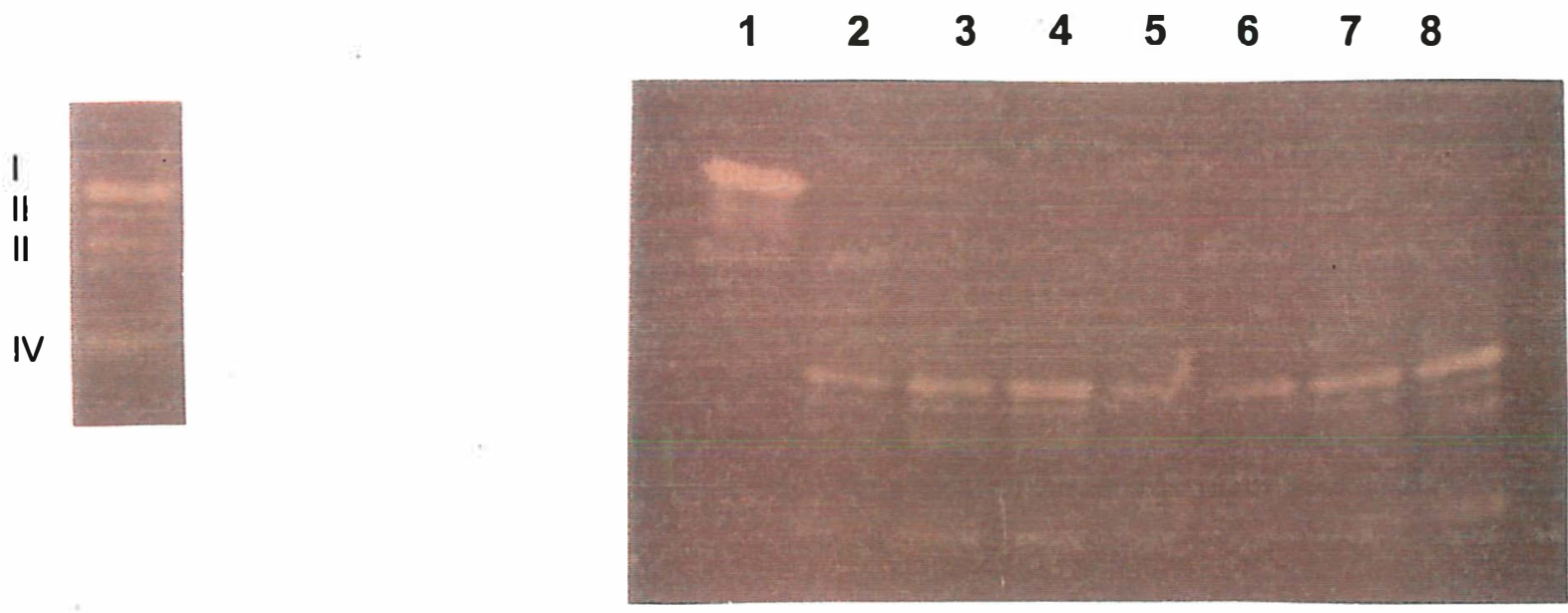

Figura 18: Gel de atividade SOD a) As 4 bandas mostradas representam as diferentes isoformas de SOD observadas nesse estudo. As bandas foram numeradas em ordem crescente de suas eletronegatividades (I=SOD-Fe, II, III e IV= SOD Cu/Zn). b) Atividade das isoformas individuais de SOD em plantas transgênicas e controle. 1= Controle positivo [1 unidade de atividade da SOD bovina (Sigma)]. 2 e 3= Controle negativo (extrato proteíco foliar WT), 4-8= extrato proteíco das plantas transgênicas R3, R6, R7, R9 e R10, respectivamente.

\subsection{7- Fotossintese}

Um resultado definitivo relacionado à presença da leghemoglobina no interior dos cloroplastos foi a análise das atividades fotossíntética e fotorrespiratória nas plantas transformadas. Os experimentos foram realizados na Universidade de Lancaster (Inglaterra) pelo Prof. Peter Lea que analisou 20 plantas de cada transformante independente (R6, R9 e R10) e 20 plantas controle. Além disso, foram analisados outros parâmetros, tais como: condutância estomatal, concentração interna de $\mathrm{CO}_{2}$, transpiração, e uso 
eficiente da água. Para todos os parâmetros avaliados, nenhuma variação foi observada entre os transformantes e as plantas controle (não mostrados). 


\section{5- DISCUSSÃO}

O aumento da produção vegetal tem sido um dos principais objetivos do melhoramento de plantas. Utilizando técnicas de biologia molecular, introduziu-se a leghemoglobina de soja no interior dos cloroplastos de fumo a fim de testar seu efeito em alterar a relação $\mathrm{CO}_{2} / \mathrm{O}_{2}$ nas proximidades do sítio ativo da Rubisco. Desta forma, esperava-se que a reação de carboxilação fosse favorecida aumentando consequentemente, o processo fotossintético.

A descoberta e caracterização da atividade de oxigenase da Rubisco (Ogren, 1984), responsável pelo mecanismo da fotorrespiração nas plantas $C_{3}$, e sua conhecida ineficiência (Hartman \& Harpel, 1994), tem atraido uma grande atenção dos pesquisadores. Esta propriedade da Rubisco afeta a fixação do $\mathrm{CO}_{2}$ e, consequentemente, a eficiência fotossintética. Assim sendo, tentativas de se redesenhar a enzima visando melhorar alguns parâmetros cinéticos como a atividade carboxilase e sua especificidade pelo $\mathrm{CO}_{2}$ não tiveram sucesso.

No presente trabalho, optou-se por abordar o problema de uma diferente maneira, sem entretanto modificar a estrutura da enzima, mas tentando alterar o ambiente da Rubisco no interior dos cloroplastos, via diminuição da pressão parcial do oxigênio utilizando as propriedades removedoras de $\mathrm{O}_{2}$ da leghemoglobina.

O peptídeo de trânsito da Rubisco ( $r b c S$ ) foi a primeira sequência de direcionamento usada para introduzir uma proteína estrangeira no interior dos cloroplastos in vivo (Van den Broeck et al., 1985). Desde então, o peptídeo 
de trânsito rbcS vem sendo usado com sucesso em vários trabalhos de importação de proteínas no interior da organela (Boutry et al., 1987; Wan et al., 1996). Por outro lado, a leghemoglobina é uma proteína monomérica que tem uma alta afinidade por oxigênio. A análise cinética de 14 hemoglobinas de plantas mostrou que a taxa de ligação ao oxigênio pela Lba de soja é uma das mais altas (Gibson et al., 1989).

Duas construções gênicas foram utilizadas na transformação de plantas de fumo. Primeiramente, a Lba foi dirigida aos cloroplastos, enquanto que na segunda construção a Lba foi expressa no citosol. Plantas transgênicas foram obtidas, das quais aproximadamente $80 \%$ expressaram o gene Iba. A análise via "Western Blotting" de uma fração enriquecida em cloroplastos mostrou que a leghemoglobina foi importada na organela das plantas transformadas com a construção Bin2-35SrbcSlba. Além disso, foi observado que o precursor rbcS-Iba foi corretamente processado, produzindo uma proteína madura com o tamanho esperado. Este resultado é importante pois em um trabalho semelhante, Dieryck et al. (1997) não conseguiram importar a hemoglobina humana $(\mathrm{Hb})$ em cloroplastos de tabaco, apesar da presença da sequência de direcionamento da Rubisco. A proteína $\mathrm{Hb}$ foi acumulada apenas em sementes e raizes das plantas transformadas.

Para examinar os efeitos fisiológicos oriundos da presença da leghemoglobina no interior dos cloroplastos, várias experiências foram realizadas. Caso as plantas apresentassem uma maior atividade fotossintética, via aumento da atividade de carboxilase da Rubisco, seriam observadas alterações no metabolismo primário dos transformantes. Vale destacar a fotossíntese, diminuição da fotorrespiração, aumento dos niveis de carboidratos e matéria seca, além de reflexos sobre o sistema enzimático relacionado à proteção contra o estresse oxidativo. Desta forma, vários parâmetros fisiológicos e bioquímicos foram analisados ao longo do trabalho. Primeiramente, foram caracterizadas plantas das gerações $R_{0}$ e $R_{1}$. Entretanto, vale ressaltar que as primeiras análises efetuadas serviram mais para o ajuste 
das metodologias, uma vez que é sabido que há uma importante variação entre plantas destas gerações. Isto é, as plantas da geração $R_{0}$ são aquelas oriundas diretamente da transformação in vitro. Portanto, são plantas que sofreram um estresse pronunciado, principalmente pela passagem do sistema in vitro para ex vitro. Já as plantas da geração $R_{1}$, provenientes da auto-fecundação das plantas da geração $R_{0}$, apresentam um tipo de segregação mendeliana do tipo $3: 1$, no caso de apenas uma inserção do gene de interesse. Assim, tem-se uma população segregante formada por plantas com diferentes niveis de expressão, o que faz com que os resultados apresentem altos desvios padrões. Portanto, para análises fisiológicas, há necessidade de se trabalhar com plantas mais homogêneas no que diz respeito à expressão do transgene. Assim, há uma preferência por trabalhos com plantas da geração $R_{2}$, sobretudo aquelas homozigóticas para o gene de interesse.

$A$ análise das plantas da geração $R_{1}$ indicou algumas variações com relação ao controle (plantas não transformadas). Entretanto, estes resultados foram tomados com precaução frente aos aspectos expostos acima. Os resultados obtidos com plantas da geração $R_{2}$ para todos os parâmetros, entretanto, mostraram não haver nenhuma alteração em relação ao controle, após análise estatística. Além disso, alguns dados foram contrários a resultados obtidos anteriormente por Holmberg et al. (1997), quando da expressão de uma hemoglobina $(\mathrm{Hb})$ bacteriana em plantas de fumo, notadamente, quanto aos niveis de clorofila $b$ e aumento da biomassa. $O$ que poderia explicar tais diferanças? Primeiramente, há que levar em conta que no trabalho com a $\mathrm{Hb}$ bacteriana, os autores trabalharam com plantas da geração $R_{1} e$, surpreendentemente, apenas dois transformantes independentes foram avaliados. Um outro aspecto que levanta dúvidas é a alta afinidade da Lba de soja (< $100 \mathrm{nM}$ ) por oxigênio em relação à $\mathrm{Hb}$ bacteriana (6.000 nM). Portanto, tais resultados devem ser tomados com relativa precaução, sobretudo pelo reduzido número de plantas analisado. 
Qual seria então, a razão para explicar a ausência de efeitos causados por uma proteína que tem uma altíssima afinidade pelo oxigênio? Uma possibilidade que vem sendo considerada refere-se à baixa concentração da leghemoglobina no interior dos cloroplastos. Dados enviados pelo Prof. Gautan Sarath da Universidade de Nebraska (USA), colaborador do trabalho, estimam que a expressão da Lba no interior dos cloroplastos seja de $0,01-0,1 \%$ do total das proteinas solúveis. Essa concentração é muito baixa quando comparada à existente nas células infectadas dos nódulos de soja. Neste tecido de soja, a Lba representa aproximadamente $25 \%$ do extrato proteico total. Ou seja, a concentração de oxigênio na superfície do bacterióide é inferior à $10 \mathrm{nM}$ (Gibson et al., 1989). Segundo Hill (1998), uma concentração elevada é necessária para criar um gradiente onde a leghemoglobina se associa ao oxigênio mais rapidamente que sua taxa de difusão. Além disso, o autor estima que a relação leghemoglobina/oxigênio nos nódulos esteja em torno de 10.000 vezes.

Sabe-se que durante o período luminoso, o cloroplasto torna-se rapidamente o compartimento mais aeróbico da natureza. $A 25^{\circ} \mathrm{C}$ a concentração de $\mathrm{O}_{2}$ no interior dos plastídeos fotossintetizantes é estimada entre 275 à $300 \mu \mathrm{M}$ (Robinson, 1988). Nestas concentrações, mesmo que a leghemoglobina esteja no seu estado funcional, seria necessária a sua presença em elevadas concentrações de forma alterar a relação $\mathrm{CO}_{2} / \mathrm{O}_{2}$ no sítio de carboxilação. Comparando-se as concentrações de oxigênio encontradas na superfície do bacterióide ( $<10 \mathrm{nM}$ ) com aquelas presentes no interior dos cloroplastos $(300 \mu \mathrm{M})$, observa-se uma variação superior a 30.000 vezes. Assim sendo, por maior afinidade que a Lba possa ter ao $\mathrm{O}_{2}$, suas concentrações no interior da organela teriam que ser tão altas que provavelmente interfeririam no funcionamento dos cloroplastos.

Um outro aspecto que merece ser considerado é o estado funcional da proteina no interior da organela. Pode-se especular que a ausência de efeitos sobre a fisiologia das plantas deva-se ao fato da proteína não estar 
funcional. No entanto, a hemoglobina humana $(\mathrm{Hb})$, que é muito mais complexa que a Lba de soja devido à sua estrutura tetramérica, mostrou-se funcional no interior dos cloroplastos de tabaco (Dyerick et al., 1997). Além disso, a observação de que uma hemoglobina é encontrada naturalmente associada aos cloroplastos da alga unicelular Chlamydomonas eugametos (Couture et al., 1994), reforçam fortemente a hipótese de que a Lba esteja na sua forma funcional nas plantas transformadas. 


\section{6- CONCLUSÃO}

Tendo em vista os resultados obtidos, pode-se concluir que:

- A leghemoglobina de soja , quando fusionada ao peptídeo de trânsito da subunidade menor da Rubisco de ervilha, foi eficientemente importada e processada no interior dos cloroplastos de plantas de fumo.

- A leghemoglobina, apesar de sua alta afinidade pelo oxigênio, não mostrou-se eficiente em alterar a relação $\mathrm{CO}_{2} / \mathrm{O}_{2}$ nas proximidades do sítio ativo da Rubisco, pois as plantas analisadas não mostraram aumento nos conteúdos de matéria seca, clorofila a e $b$, sacarose, amido e assimilação de $\mathrm{CO}_{2}$.

- As enzimas catalase, glutationa redutase e superóxido dismutase, envolvidas no processo de detoxificação das espécies reativas de oxigênio, também não tiveram suas atividades modificadas com a presença da leghemoglobina.

Esses resultados sugerem que, para alterar o metabolismo aeróbico no interior dos cloroplastos, uma alta concentração de leghemoglobina deve estar presente para assorciar-se ao oxigênio mais rapidamente que a taxa de difusão desta molécula. 


\section{REFERÊNCIAS BIBLIOGRÁFICAS}

ACKRELL, B.A.C.; ERICKSON, S.K.; JONES, C.W. The respiratory chain NADPH dehydrogenase of Azotobacter vinelandii. European Journal of Biochemistry, v.26, p. 387-392, 1972.

ALLEN, R.D. Dissection of oxidative stress tolerance using transgenic plants. Plant Physiology, v.107, p. 1049-1054, 1995.

ALSCHER, R.G.; DONAHUE, J.L.; CRAMER, C.L. Reactive oxygen species and antioxidants: relationships in green cells. Physiologia Plantarum, v.100, p.224-233, 1997.

ANDERSON, B.; STYRING, S. Photosystem II: Molecular organization, function and acclimatation. In: KROGMANN, D.W. (Ed.) Currents Topics in Bioenergetics. London: Academic Press, 1991, v.16, p.2-81.

ANDERSON, C.R.; JENSEN, E.O.; LLEWELLYN, D.J.; DENNIS, E.S.; PEACOCK, W.J. A new hemoglobin gene from soybean: a role for hemoglobin in all plants. Proceedings of the National Academy of Sciences of the USA, v.93, p.5682-5687, 1996.

ANDREWS, T.J.; LORIMER, G.H. Rubisco: structure, mechanisms and prospects for improvement. In: STRUMPF, P.K.; CONN, E.E. (Ed.) The biochemistry of plants. London: Academic Press Publishers, 1987. v.10, p. 131-219.

APPLEBY, C.A. Leghemoglobin and Rhyzobium respiration. Annual Review of Plant Physiology, v.35, p.443-478, 1984. 
ARREDONDO-PETER, R.; HARGROVE, M.S.; MORAN, J.F., SARATH, G.; KLUCAS, R.V. Plant hemoglobins. Plant Physiology, v.118. p. 1121-1125, 1998.

ARNON, D.I. Copper enzymes in isolated chloroplast. Polyphenoloxidase in Beta vulgaris. Plant Physiology, v.24, p.1-15, 1949.

AZEVEDO, R.A.; ALAS, R.M.; SMITH, R.J.; LEA, P.J. Response of antioxidant enzymes to transfer from elevated carbon dioxide to air and ozone fumigation in the leaves and rrots of wild-type and a catalase mutant of barley. Physiologia Plantarum, v.104, p.280-292, 1998.

BARTLET, S.G.; GROSSMAN, A.R.; CHUA, N-H. Methods in chloroplast molecular biology. In: EDEIMAN, M.; HALICK, R.B.; CHUA, N-H. (Ed) In vitro synthesis and uptake of cytoplasmatic-synthesized chloroplast proteins. Amsterdan: Elsevier North-Holland Biomedical Press, 1982. p.1081-1091.

BADGER, M.R.; SHARKEY, T.D.; von CAEMMERER, S. The relationship between steady-state gas exchange of bean leaves and the levels of carbonreduction-cycle intermediates. Planta, v.160, p. 305-313, 1984.

BEAUCHAMP, C.H.; FRIDOVICH, I. Superoxide dismutase: Improved assays and an assay applicable to acrylamide gels. Analytical. Biochemistry. v.44, p. 276-287, 1971.

BECANA, M.; KLUCAS, R.V. Enzimatic and nonenzimatic mechanisms for ferric leghemoglobin reduction in legume root nodules. Proceedings of the National Academy of Sciences of the USA, v.87, p.7295-7299, 1990. 
BECANA, M.; KLUCAS, R.V. Oxidation and reduction of leghemoglobin in root nodules of leguminous plants. Plant Physiology, v.97, p.1217-1221, 1992.

BECK, E.; ZIEGLER, P. Biosynthesis and degradation of starch in higher plants. Annual Review of Plant Physiology and Plant Molecular Biology, v.40, p. 95-117, 1989.

BERRY, J.A.; LORIMER, G.H.; PIERCE J.; SEEMANN, J.R.; MEEKS, J.; FREAS, S. Isolation, indentification, and synthesis of 2--carboxyarabinitol 1phosphate, a diurnal regulator of ribulose-bisphosphate carboxylase activity. Proceedings of the National Academy of Sciences of the USA. v.84, p. 734-738, 1987.

BLACK, E.C,; BROWN, R.H.; MOORE, R.C. Plant photosynthesis. In: DOBEREINER, J; BURRIS, R.H.; HOLLAENDER (Ed.) Limitations and potentials for biological nitrogen fixation in the tropics. Plenum Press, 1977. P.35-170.

BOUTRY, M.; NAGY, F.; POULSEN, C.; AOYAGI, K.; CHUA, N-H. Targeting of bacterial chloramphenicol acetyltransferase to mitochondria in transgenic plants. Nature, v.328, p.340-342, 1987.

BOWLER, C.; VAN MONTAGU, M.; INZE, D. Superoxide dismutase and stress tolerance. Annual Review of Plant Physiology and Plant Molecular Biology, v.43, p. 83-116, 1992.

BOWES, G.; OGREN, W.L.; HAGEMAN, R.H. Phosphoglycolate production catalyzed by ribulose diphosphate carboxylase. Biochemical and Biophysical Research Communications, v.45, p. 716-722, 1971. 
BRADFORD, M.M. A rapid and sensitive method for the quantification of microgram quantities of protein utilizing the principle of protein-dye binding. Analytical Biochemistry, v.72, p.248-254, 1976.

BRISSON, L.F.; ZELITCH, I.; HAVIR, E.A. Manipulation of catalase levels produces altered photosynthesis in transgenic tobacco plants. Plant Physiology, v.116, p.259-269, 1998.

BRISSON, N.; VERMA, D.P.S. Soybean leghemoglobin gene family: Normal, pseudo, and truncated genes. Proceedings of the National Academy of Sciences of the USA, v.79, p. 4055-4059, 1982.

BROGLIE, R.; CORUZZI, G.; LAMPPA, G.; KEITH, B.; CHUA, N.-H. Structural analysis of nuclear genes coding the precursor to the small subunit of wheat ribulose-1,5-bisphosphate carboxylase. Biotechnology, v.1, p.55-61, 1983.

BUCHANAN, B.B. Regulation of $\mathrm{CO}_{2}$ assimilation in oxygenic photosynthesis: The ferredoxin/thiorredoxin system. Archives of Biochememistry and Biophysics, v.288, p. 1-9, 1991.

CASANO, L.M.; MARTIN, M.; SABATER, B. Sensitivity of superoxide dismutase transcript levels and activities to oxidative stress is lower in mature-senescent than in young barley leaves. Plant Physiology, v.106, p. 1033-1039, 1994.

CHAUMONT, F.; SILVA-FILHO, M. DE C.; THOMAS, D.; LETERME, S.; BOUTRY, M. Truncated presequences of mitochondrial $F_{1}$ - ATPase $\beta$-subunit from Nicotiana plumbaginifolia transport CAT and GUS proteins into mitochondria of transgenic tobacco. Plant Molecular Biology, v.24, p.631$641,1994$. 
CHOLLET, R.; OGREN, W.L. Regulation of photorespiration in $\mathrm{C}_{3}$ and $\mathrm{C}_{4}$ species. The Botanical Review, v.137, p. 79, 1975.

COUTURE, M.; CHAMBERLAND, H.; St-PIERRE, B.; LAFONTAINE, J.; GUERTIN, M. Nuclear genes enconding chloroplast hemoglobins in the unicellular green alga Chlamydomonas eugametos. Molecular and General Genetics, v.243, p. 185-197, 1994.

CREISSEN, G.P.; BROADBENT, P.; KULAR, B.; REYNOLDS, H.;WELLBURN, A.R.; MULLINEAUX, P.M. Manipulation of glutathione reductase in transgenic plants: implications for plants' responses to environmental stress. Proceedings of the Royal Society of Edinburgh, v.102, p. 167-175, 1994.

CREISSEN, G.P.; REYNOLDS, H.; XUE, Y.; MULLINEAUX, P.M. Simultaneous targeting of pea glutathione reductase and of a bacterial fusion protein to chloroplast and mitochondria in transgenic tobacco. Plant Journal, v.8, p. 167-175, 1995.

DEAN, C.; VAN DEN ELZEN, P.; TAMAKI, S.; DUNSMIER, P.; BEDBROOK, J. Linkage and homology analysis divides the eight genes for the small subunit of petunia ribulose-1,5-bisphosphate carboxylase into three gene families. Proceedings of the National Academy of Sciences of the USA, v.82, p.4964-4968, 1985.

DE BOER, A.D.; WEISBEEK, P.J. Chloroplast protein topogenesis, import, sorting and assembly. Biochemica et Biophysica Acta, v.1071, p.221-253, 1991.

DYERICK, W.; PAGNIER, J.; POYART, C.; MARDEN, M.C. Human hemoglobin from transgenic tobacco. Nature, v.386, p. 29-30, 1997. 
DIETZ, K.J; HEBER, U. Light and $\mathrm{CO}_{2}$ limitation of photosynthesis and state of the reactions regenerating ribulose 1,5-bisphosphate or reducing 3phosphoglycerate. Biochimica et Biophysica Acta, v.848, p.392-410, 1986.

DIMAH, Z.H.; PAUL, M.J.; PARRY, M.A.J.; KEYS, A.J.; LAWLOR, D.W. Increased capacity for photosynthesis in wheat grown at elevated $\mathrm{CO}_{2}$ : the retationship between electron transport and carbon metabolism. Planta, v.197, p.482-489, 1995.

DONAHUE, J.L.; OKPODU, C.M.; CRAMER, C.L; GRABAU, E.A.; ALSCHER, R.G. Responses of antioxidants to paraquat in pea leaves. Plant Physiology, v.113, p. 249-257, 1997.

EDWARDS, A.; RAWSTHORNE, S.; MULLINEAUX, P.M. Subcellular distribution of multiple isoforms of glutathione reductase in leaves of pea (Pisum sativum L.). Planta, v.180, p. 278-284, 1990.

EDWARDS, K.; JOHNSTONE, C.; THOMPSON, C. A simple and rapid method for the preparation of plant genomic DNA for PCR analysis. Nucleic Acids Research, v.19, p. 1349.

ELSTNER, E.F. Oxygen activation and oxygen toxicity. Annual Review of Plant Physiology, v.33, p. 73-96, 1982.

EVANS, J.R. Photosynthesis and nitrogen relationships in leaves of $C_{3}$ plants. Oecologia, v.78, p.9-19, 1989. 
FLÜGLE, U-I.; HELDT, H.W. Metabolite translocators of the chloroplast envelope. Annual Review of Plant Physiology and Plant Molecular Biology, v.42, p. 129-144.

FOYER, C. Discovery of the most abundant inhibitor in the world? Nature, v.324, p. 211, 1986.

FOYER, C.H.; LOPEZ-DELGADO, H.; DAT, J.F.; SCOTT, I.M. Hydrogen peroxide- and glutathione-associated mechanism of acclimatory stress tolerance and signalling. Physiologia Plantarum, v.100, p. 241-254, 1997.

FURBANK, R.T.; TAYLOR, W.C. Regulation of photosynthesis in $\mathrm{C}_{3}$ and $\mathrm{C}_{4}$ Plants: A molecular approach. The Plant Cell, v.7, p.797-807, 1995.

GEIGER, D.R.; SERVAITES, J.C. Diurnal regulation of photosynthetic carbon metabolism in $\mathrm{C}_{3}$ plants. Annual Review of Plant Physiology and Plant Molecular Biology, v.45, p. 235-256, 1994.

GIBSON, Q.H.; WITTEMBERG, J.B.; WITTENBERG, B.A.; BOGUSZ, D.; APPLEBY, C.A. The kinetics of ligand binding to plant hemoglobins. The Journal of Biological Chemistry, v.264, p. 100-107, 1989.

GUTTERIDGE, S.; GATENBY, A. A. Rubisco Synthesis, Assembly, Mechanism, and Regulation. The Plant Cell, v.7, p.809-819, 1995.

HARTMAN, F.C.; HARPEL, M.R. Structure, function, regulation and assembly of Ribulose-1,5-biphosphate carboxylase/oxygenase. Annual Review of Biochemistry, v. 63, p.197-234, 1994. 
HATCH, M.D. Photosynthesis: The path of carbon. In: BONNER J.; VARNER J. (Ed), Plant Biochemistry. Academic Press, 1976. p.797-844.

HATCH, M.D. $\mathrm{C}_{4}$ photosynthesis: A unique blend of modified biochemistry, anatomy and ultrastructure. Biochimica et Biophysica Acta, v.895, p. 81106, 1988.

HAYAKAWA, T.; KANEMATSU, S.; ASADA, K. Occurrence of $\mathrm{Cu}, \mathrm{Zn}$ superoxide dismutase in the intrathylakoid space of spinach chloroplasts. Plant Cell Physiology, v.25, p. 883-889, 1984.

HAVIR, E.A.; McHALE, N.A. Regulation of catalase activity in leaves of Nicotiana sylvestris by high $\mathrm{CO}_{2}$. Plant Physilogy, v.89, p. 952-957, 1989.

HEBER, U.; SCHREIBER, U.; SIEBKE, K.; DIETZ, K.J. Relationship between light-driven electron transport, carbon reduction and carbon oxidation in photosynthesis. In: ZELITCH I. (Ed) Perspectives in biochemical and genetic regulation of photosynthesis. New York: Wiley-Liss, 1990. p.1737.

HEROLD, A. Regulation of photosynthesis by sink activity: the missing link. New Phytologist, v.86, p. 131-144, 1980.

HILL, R.D. What are hemoglobins doing in plants ? Canadian Journal of Botany, v.76, p. 707-712, 1998.

HOLMBERG, N.; LILIUS, G.; BAILEY, J.E., BULOW, L. Transgenic tobacco expressing Vitreoscilla hemoglobin exhibts enhanced growth and altered metabolite production. Nature Biotechnology, v.15, p.244-247, 1997. 
HOLTMAN, W.L.; de GRAFF, A.M.; LEA, P.J.; KIJNE, J.W. Light dependent expression of two catalase subunits in leaves of barley seedlings. Journal of Experimental Botany, v.49, p. 1303-1306, 1998.

HUANG, J.; HACK, E.; THORNBURG, W.; MYERS, A.M. A yeast mitochondrial leader peptide functions in vivo as a dual targeting signal for both chloroplast and mitochondria. Plant Cell, v.2, p.1249-1260, 1990.

HUDSON, G.S.; EVANS, J.R.; CAEMMERER, S.; ARVIDSSON, Y.B.C.; ANDREWS, T.J. Reduction of ribulose-1,5-bisphosphate carboxylaseoxygenase content by antisense RNA reduces photosynthesis in transgenic tobacco plants. Plant Physiology, v. 98, p. 294-320, 1992.

HURT, E.C.; SOLTANIFAR, N.; GOLDSMITH-CLERMONT, M.; ROCHAIX, J.D.; SCHATZ, G. The cleavable presequence of an imported chloroplast protein directs attached polypeptides into yeast mitochondria. The EMBO Journal, v.5, p.1343-1350, 1986.

INZÉ, D.; VAN MONTAGU, M. Oxidative stress in plants. Current Opinion in Biotechnology, v.6, p. 153-158, 1995.

JI, L.; BECANA, M.; KLUKAS, R.V. Involvement of molecular oxygen in the enzyme-catalyzed NADH oxidation and Ferric leghemoglobin reduction. Plant Physiology, v.100, p.33-39, 1992.

JI, L.; BECANA, M.; SARATH, G.; KLUKAS, R.V. Cloning and sequence analysis of a CDNA encoding ferric leghemoglobin reductase from soybean nodules. Plant Physiology, v.104, p.453-459, 1994. 
JONES, M.G.K.; OUTLAW, W.H.; LOWRY, O.H. Procedure for the assay of sucrose in range $10^{-7}-10^{-14}$ moles. Plant Physiology, v.60, p. 379-383, 1977.

JORDAN, D.B.; CHOLLET, R. Inhibition of ribulose bisphosphate carboxylase by substrate ribulose-1,5-bisphosphate. The Journal of Biological Chemistry, v.258, p.13752-13758, 1983.

KAISER, G.; HEBER, V. Sucrose transport into vacuoles isolated from barley mesophyll protoplast. Planta, v.161, p.562-568.

KAISER, W. Carbon metabolism of chloroplast in the dark. Planta, v.144, p.193200, 1979.

KAVANAGH, T.A; JEFFERSON, R.A; BEVAN, MW. Targeting a foreign protein to chloroplasts using fusions to the transit peptide of a chlorophyll $\mathrm{a} / \mathrm{b}$ binding. Molecular and General Genetics, v.215, p. 38-45, 1988.

KENDALL, A.C.; KEYS, A.J.; TURNER, J.C.; LEA, P.J.; MIFLIN, B.J. The isolation and characterization of a catalase-deficient mutant of barley (Hordeum vulgare L.). Planta, v.159, p. 505-511, 1983.

KNIGHT, S.; ANDERSON, I.; BRANDEN, C.-I. Crystallographic analysis of ribulose 1,5-bisphosphate carboxylase from spinach at $2,4 \AA$ resolution: Subunit interactions and active site. Journal of Molecular Biology. V.215, p.113-160, 1990.

KOBZA, J.; SEEMANN, J.R. Mechanisms for the light regulation of ribulose-1,5bisphosphate carboxylase activity and photosynthesis in intact leaves. 
Proceedings of the National Academy of Sciences of the USA, v.85, p. 3815-3819, 1988.

KRAUS, T.E.; McKERSIE, B.D.; FLETCHER, R.A. Paclobutrazol-induced tolerance of wheat leaves to paraquat may involve increased antioxidant enzyme activity. Journal of Plant Physiology, v.145, p.570-576, 1995.

KRETOVICH, W.L.; ROMANOV, V.I.; YUSHKOVA, L.A.; SHRAMKO, V.I.; FEDULOVA, N.G. Nitrogen fixation and poly- $\beta$-hydroxybutyric acid content in bacteroids of Rhizobium lupini and Rhizobium leguminosarum. Plant Soil, v.48, p. 291-302, 1977.

LABATE, C.A.; LEEGOOD, R. Influence of low temperature on respiration and content of phosphorylated intermediates in darkened barley leaves. Plant Physiology, v.91, p. 905-910, 1989.

LAEMMLI, U.K. Cleavage of structural proteins during the assembly of the head of bacteriophage $T_{4}$. Nature, v.227, p. 680-685, 1970.

LAING, W.A.; OGREN, W.L.; HAGEMAN, R.H. Regulation of soybean net photosynthetic $\mathrm{CO}_{2}$ fixation by the interaction of $\mathrm{CO}_{2}, \mathrm{O}_{2}$, and ribulose 1,5diphosphate carboxylase. Plant Physiology. v.54, p. 678-685, 1974.

LARSON, R.A. The antioxidants of higher plants. Phytochemistry, v.27, p.969978, 1988.

LEEGOOD, R.C. Regulation of photosynthetic $\mathrm{CO}_{2}$-pathway enzymes by light and other factors. Photosynthesis Research, v.6, p. 247-259, 1985. 
LEHNINGER, A.L.; NELSON, D.L.; COX, M.M. Principles of Biochemistry. New York: Worth Publishers, 1993. 1013p.

LORIMER, G.H.; MIZIORKO, H. Carbamate formation of the $\varepsilon$-amino group of a lysyl residue as the basis for the activation of ribulose bisphosphate carboxylase by $\mathrm{CO}_{2}$ and $\mathrm{Mg}^{+2}$. Biochemistry, v.19, p.5321-5328, 1980 .

LORIMER, G.H. The carboxylation and oxygenation of ribulose 1,5bisphosphate: The primary events in photosynthesis and photorespiration. Annual Review of Plant Physiology. v.32. p.349-383, 1981.

LOWRY, O.; PASSONNEAU, J.V. A flexible system of enzimatic analysis. New York: Academic Press, 1972.

MARTIN, C.; SMITH, A.M. Starch Biosynthesis. The Plant Cell, v.7, p.971-985, 1995.

MATE, C.J.; vonCAEMMERER, S.; EVANS, J.R.; HUDSON, G.S.; ANDREWS, T.J. The relationship between $\mathrm{CO}_{2}$-assimilation rate, Rubisco carbamylation and Rubisco activase content in activase-deficient transgenic tobacco suggests a simple model of activase action. Planta, v.198, p. 604-613, 1996.

MATTERS, G.L.; SCANDALIOS, J.G. Effect of free radical generating herbicide paraquat on the expression of superoxide dismutase (SOD) genes in maize. Biochimica et Biophysica Acta, v.882, p. 29-38, 1986.

MURASHIGE, T.; SKOOG, F. A revised medium for rapid growth and bioassays with tobacco tissue culture. Physiologia Plantarum, v.15, p.473-497, 1962. 
OGREN, W.L. Photorespiration: pathways, regulation, and modification. Annual Review of Plant Physiology, v.35, p. 415-442, 1984.

PIERCE, J. Prospects for manipulating the substrate specificity of ribulose bisphosphate carboxylase/oxygenase. Physiologia Plantarum, v.72, p.690698, 1988.

PILON, M.; de KRUIJFF, B.; WEISBEEK, P. New insights into the import mechanism of ferredoxin precursor into chloroplast. Journal of Biological Chemistry, v.267, p. 2548-2556, 1992.

PFALLER, R.; PFANNER, N.; NEUPERT, W. Mitochondrial protein import. bypass of proteinaceous surface receptors can occur with low specificity and efficiency. The Journal of Biological Chemistry, v.264, p.34-39, 1989.

PORTIS Jr. A.R. Rubisco activase. Biochimica et Biophysica Acta, v.1015, p. 15-28, 1990.

PORTIS Jr. A.R. Regulation of ribulose 1,5-bisphophate carboxylase/oxygenase activity. Annual Review of Plant Physiology and Plant Molecular Biology, v.43, p. 415-437, 1992.

PREISS, J.; LEVI, C. Starch biosynthesis and degradation. In: HATCH, M.D. \& BOARDMAN, N.R. (Ed.) The Biochemistry of Plants. London: Academic Press, 1980, v.3, p.371-423.

PREISS, J. Biosynthesis of starch and its degradation. In: PREISS, J. (Ed.) Biochemistry of Plants. San Diego: Academic Press, 1988. v.13, p.181-254. 
PREISS, J. Biology and molecular biology of starch synthesis and its regulation. In: MIFFLIN B.J. (Ed.) Oxford Surveys of Plant Molecular and Cell Biology. Oxford: Oxford University Press, 1991. v.7, p. 59-114.

RAO, M.V.; PALIYATH, G.; ORMROD, P.P. Ultraviolet-B and ozone-induced biochemical changes in anti-oxidant enzymes of Arabidopsis thaliana. Plant Physiology, v.110, p. 125-136, 1996.

RIGAUD, J.; PUPPO, A. Effect of nitrite upon leghemoglobin and interaction with nitrogen fixation. Biochemica et Biophysica Acta, v.497,p.702-706, 1977.

ROBINSON, J.M. Does $\mathrm{O}_{2}$ photoreduction occur within chloroplasts in vivo? Physiologia Plantarum, v.72, p.666-680, 1988.

SALVUCCI, M.E. Regulation or Rubisco activity in vivo. Physiologia Plantarum, v.77, p. 164-171, 1989.

SALVUCCI, M.E., PORTIS, A.R.Jr.; OGREN, W.L. A soluble chloroplast protein catalyzes ribulosbisphosphate carboxylase/oxygenase activation in vivo. Photosynthesis Research, v.7, p. 193-201, 1985.

SKADSEN, R.W.; SCHULZE-LEFERT, P.; HERBST, J.M. Molecular cloning, characterization and expression analysis of two catalase isozymes genes in barley. Plant Molecular Biology, v.29, p. 1005-1014, 1995.

SCANDALIOS, J.G. Response of plant antioxidant defense genes to environmental stress. Advances in Genetics, v.28, p. 1-41, 1990.

SCANDALIOS, J.G. Oxygen stress and superoxide dismutases. Plant Physiology, v.101, p.7-12, 1993. 
SCANDALIOS, J.G. Regulation and properties of plant catalases. In: FOYER, C.H.; MULLINEAUX, P.M. (Ed) Causes of photooxidative stress and amelioration of defense systems in plants. Boca Raton FL: CRC Press, 1994. p. 275-315,

SEN GUPTA, A.; HEINEN, J.L.; HOLADAY, A.S.; BURKE, J.J.; ALLEN, R.D. Increased resistance to oxidative stress in transgenic plants that overexpress chloroplastic $\mathrm{Cu} / \mathrm{Zn}$ superoxide dismutase. Proceedings of the National Academy of Sciences of the USA, v.90, p. 1629-1633, 1993.

SHARKEY, T.D.; STITT, M.; HEINEKE, D.; GERHARDT, R.; RASCHKE, K.; HELDT, H.M. Limitation of photosynthesis by carbon metabolism. $\mathrm{O}_{2-}$ insensitive $\mathrm{CO}_{2}$ uptake results from limitation of triose phosphate utilization. Plant Physiology, v.81, p. 1123-1129, 1986.

SILVA-FILHO, M DE C. Challenging the specificity of protein import into plant mitochondria and chloroplasts. Louvain, 1994. 86p. Thesis (Ph.D.) University Catholique de Louvain.

SILVA-FILHO, M. DE C.; CHAUMONT, F.; LETERME, S.; BOUTRY, M. Mitochondria and chloroplast targeting sequences in tandem modify protein import specifity in plant organelles. Plant Molecular Biology, v.30, p.769780, 1996.

SILVA FILHO, M. DE C.; WIEËRS, M.-C.; FLÜGGE, U.-I.; CHAUMONT, F.; BOUTRY, M. Different in vitro and in vivo targeting properties of the transit peptide of a chloroplast envelope inner membrane protein. The Journal of Biological Chemistry, v.272, p. 15264-15269, 1997. 
SILVA-FILHO, M. DE C. Translocation of a reporter protein into mitochondria is mediated by a chloroplast transit peptide and follows a normal import route. Journal of Plant Physiology, v.154, p. 51-54, 1999.

SMITH, I.K.; VIERHELLER, T.L.; THORNE, C.A. Assay of glutathione reductase in crude tissue homogenates using 5,5'-dithiobis(2-nitrobenzoic acid). Analytical Biochemistry, v.175, p.408-413, 1988.

SOMERVILLE, C.R.; PORTIS, A R.; OGREN,W.L. A mutant of Arabidopsis thaliana which lacks activation of RuBP carboxylase in vivo. Plant Physiology, v.70, p.381-387, 1982.

SOWA, A.W.; DUFF, S.M.G.; GUY, P.; HILL, R.D. Altering hemoglobin levels changes energy status in maize cells under hypoxia. Proceedings of the National Academy of Sciences of the USA, v.95, p. 10317-10321, 1998.

SPREITZER, R. Genetic dissection of rubisco structure and function. Annual Review of Plant Physiology and Plant Molecular Biology, v.44, p.411-434, 1993.

STEEL, C.C.; NAIR, N.G. Oxidative protective mechanism of resistance to the dicarboximide fungicide iprodione in Alternaria alternata. Journal of Phytopathology, v.143, p. 531-535, 1995.

STITT, M. Fructose 2,6-bisphosphate and plant carbohydrate metabolism. Plant Physiology, v.84, p. 201-204, 1987. 
STITT, M.; WILKE, I.; FEIL, R.; HELDT, H.W. Coarse control of sucrosephosphate synthase in leaves: alterations of the kinetic properties in response to the rate of photosynthesis and accumulation of sucrose. Planta, v.174, p. 217-230, 1988.

STITT, M. Fructose 2,6-bisphosphate as a regulatory molecule in plants. Annual Review of Plant Physiology and Plant Molecular Biology, v.41, p.153-185, 1990.

STITT, M. Rising $\mathrm{CO}_{2}$ levels and their potential significance for carbon flow in photosynthetic cells. Plant Cell Enviroment, v.14, p.741-762, 1991.

STITT, M.; SONNEWALD, U. Regulation of metabolism in transgenic plants. Annual Review of Plant Physiology and Plant Molecular Biology, v.46, p. 341-368, 1995.

TAYLOR, E.R.; NIE, X.Z.; MACGREGOR, A.W.; HILL, R.D. A ceral haemoglobin gene is expressed in seed and root tissues under anaerobic conditions. Plant Molecular Biology, v.24, p. 853-862, 1994.

TOWBIN, H.; STAEHELIN, T.; GORDON, J. Eletrophoretic transfer of proteins from polyacrylamide gels to nitrocellulose sheets: Procedure and some applications. Proceedings of the National Academy of Sciences of the USA, v: 76, p.4350-4354, 1979.

TSANG, E.W.T.; BOWLER, C.; HÉROUART, D.; VAN CAMP, W.; VILLARROEL, R.; GENETELLO, C.; VAN MONTAGU, M.; INZÉ, D. Differential regulation of superoxide dismutases in plants exposed to environmental stress. The Plant Cell, v.3, p. 783-792, 1991. 
VAN CAMP, W.; WILLEKENS, H.; BOWLER, C.; VAN MONTAGU, M.; INZÉ, D.; REUPOLD POPP, P.; SANDERMANN, H.; LANGEBARTELS, C. Elevated levels of superoxide dismutase protect transgenic plants against ozone damage. Biotechnology, v.12, p. 165-168, 1994.

VAND DEN BROECK, G.; TIMKO, M.P.; KAUSCH, A.P.; CASHMORE, A.R.; VAN MONTAGU, M.; HERRERASTRELA, L. Targeting of a foreign protein to chloroplasts by fusion to transit peptide from the small subunit of ribulose 1,5biphosphate carboxylase. Nature, v.313, p. 358-363, 1985.

VERNON, L.P. Spectrophotometric determination of chlorophylls and pheophitins in plants extracts. Analytical Chemistry, v.32, p. 1144-1150, 1960.

WAN, J.; BLAKELEY, S.D.; DENNIS, D.T.; KO, K. Transit peptides play a role in the preferential import of proteins into leucoplasts and chloroplasts. The Journal of Biological Chemistry, v.271, p. 31227-31233.

WILLEKENS, H.; LANGEBARTELS, C.; TIRE, D.; VAN MONTAGU, M.; INZÉ, D.; VAN CAMP, W. Differential expression of catalase genes in Nicotiana plumbaginifolia (L.) Proceedings of the National Academy of Sciences of the USA, v.91, p. 10450-10454, 1994.

WILLEKENS, H.; CHAMNONGPOL, S.; DAVEY, M.; SCHRAUDNER, M.; LANGEBARTELS, C.; VAN MONTAGU, M.; INZÉ, D.; VAN CAMP, W. Catalase is a sink for $\mathrm{H}_{2} \mathrm{O}_{2}$ and is indispensable, for stress defence in $\mathrm{C}_{3}$ plants. The EMBO Journal, v.16, p. 4806-4816, 1997.

ZELITCH, I. The close relationship between net photosynthesis and crop yield. BioScience, v.32, p. 796-802, 1982. 
ZELITCH, I. Control of plant productivity by regulation of photorespiration. Regulation of photorespiration can have beneficial effects on net photosynthesis. BioScience, v.42, p. 510-516, 1992.

ZHU, G.; SPREITZER, R.J. Directed mutagenesis of chloroplast ribulose-1,5bisphosphate carboxylase/oxygenase. Loop 6 substitutions complement for structural stability but decrease catalytic efficiency. The Journal of Biological Chemistry, v.271, p. 18494-18498, 1996. 


\section{ANEXO}

(Artigo submetido à publicação) 
Marcio C. Silva-Filho

Departamento de Genética, Escola Superior de Agricultura "Luiz de Queiroz", Universidade de São Paulo, Av. Pádua Dias, 11, Caixa Postal 83, 13400-970 Piracicaba, SP, Brazil

Tel: 55194294125

Fax: 55194336706

E-mail: mdcsilva@carpa.ciagri.usp.br 
Targeting of the soybean leghemoglobin to tobacco chloroplasts does not interfere with aerobic metabolism in transgenic plants

Reinaldo M. Barata ${ }^{1}$, Alejandro Chaparro ${ }^{1}$, Sabrina M. Chabregas ${ }^{1}$, Raquel González ${ }^{3}$, Carlos A. Labate ${ }^{1}$, Ricardo A. Azevedo ${ }^{1}$, Gautam Sarath ${ }^{2}$, Peter J. Lea ${ }^{3}$, and Marcio C. Silva-Filho ${ }^{1} *$

Submitted: May 28, 1999 Total word count: 5191

${ }^{1}$ Departamento de Genética, Escola Superior de Agricultura "Luiz de Queiroz", Universidade de São Paulo, Av. Pádua Dias, 11, Caixa Postal 83, 13400-970 Piracicaba, SP, Brazil

${ }^{2}$ N-226, Beadle Center, Protein Core Facility - Center for Biotechnology \& Department of Biochemistry, University of Nebraska-Lincoln, Lincoln, NE 68588-0664

${ }^{3}$ Division of Biological Sciences, University of Lancaster, Bailrigg, Lancaster, LA1 4YQ, UK

* To whom correspondence should be addressed 


\section{Abstract}

Oxygen is an essential molecule for respiration and also participates in both the primary and secondary metabolism of plant cells. Several attempts have been made to alter the aerobic metabolism of plants, especially those related to the oxygenation or carboxylation of Rubisco. However, designing a more efficient Rubisco protein is rather problematic since its structural manipulation leads frequently to an enhancement of oxygenase activity, which is responsible for photorespiratory losses. In order to reduce oxygen availability inside chloroplasts a chimeric gene, consisting of a soybean leghemoglobin cDNA $(l b a)$ ligated to the chloroplast targeting signal sequence of the Rubisco small subunit gene was introduced and expressed in Nicotiana tabacum. Lb was efficiently imported and correctly processed inside the chloroplasts in transgenic tobacco plants. Furthermore, the maximum level of $\mathrm{Lb}$ expression in leaf tissue ranged from 0.01 to $0.1 \%$. Analysis of photosynthesis, metabolite production and enzymes involved in aerobic metabolism, revealed that despite high affinity of Lb for oxygen, no significant difference was observed in relation to the control plants. These results suggest that higher Lb concentrations are required inside the chloroplasts in order that Lb may act as a more effective oxygen carrier or facilitate diffusion.

\section{Keywords}

Leghemoglobin, photosynthesis, photorespiration, oxygen.

\section{Running title}

Targeting of leghemoglobin to chloroplasts 


\section{Introduction}

At high light intensities, the chloroplast rapidily becomes the most aerobic compartment in the leaf cell. At $25^{\circ} \mathrm{C}$, oxygen in the air equilibrates with dissolved $\mathrm{O}_{2}$ in aqueous solution to produce a concentration of aproximately $250 \mu \mathrm{M}$. Under these conditions, oxygen concentrations within photosynthesizing chloroplasts have been experimentaly estimated to be 10 to $20 \%$ higher than the external aqueous environment, which is 275 to $300 \mu \mathrm{M} \mathrm{O}_{2}$ (Robinson, 1988). Oxygen acts as a substrate or cofactor in many biochemical reactions in both the primary and secondary metabolism of plants cells. For example, chlorophyll and protoporphyrin biosynthesis (von Wettstein et al., 1995), an alternative Hill oxidant: Mehler reaction (Robinson, 1988), and substrate to the oxygenase activity of ribulose-1,5-bisphosphate carboxylase/oxygenase (Rubisco) in $\mathrm{C}_{3}$ plants. Photorespiration in these plants is assumed to be responsible for as much as $40 \%$ loss of net $\mathrm{CO}_{2}$ assimilated. In this manner, the photorespiration can be considered a wasteful process since the $\mathrm{CO}_{2}$ released must be fixed again within the leaf (Zelitch, 1992).

Control of photorespiration has emerged as a primary objective in efforts to increase plant productivity in $\mathrm{C}_{3}$ crops (Keys, 1999). Elevated $\mathrm{CO}_{2}$ concentrations generally enhance photosynthesis over the short term (days) because of higher $\mathrm{CO}_{2}$ concentrations at the carboxylation site, results in an increased availability of carbohydrate for plant growth (Stitt, 1996; Moore et al., 1998). Nevertherless, due to practical limitations of increasing $\mathrm{CO}_{2}$ concentrations on a large scale, many efforts have been made to modify the properties of Rubisco to reduce the oxygenation reaction, 
especially using molecular biology techniques. The majority of results reported so far, indicate that modification of Rubisco structure reduces the oxygenase activity as well as the carboxylase activity ( Hartman and Harpel, 1994; Kanevski et al., 1999). An alternative to altering the active site of Rubisco is to modify the ratio of $\mathrm{CO}_{2} / \mathrm{O}_{2}$ in proximity to the enzyme, by targeting leghemoglobin $(\mathrm{Lb})$ to the chloroplast. Lb has a very high affinity to oxygen, and is in-planta synthesized exclusively in root nodules due to a symbiotic association of Rhizobium spp. with leguminous plants (Appleby, 1992; Becana and Klucas, 1992). Lb functions by facilitating oxygen diffusion through the cytoplasm of bacteria-infected nodule cells to membrane-enclosed bacterioids, and thereby, protecting $\mathrm{O}_{2}$ damage to nitrogenase (Bergersen, 1996; Arredondo-Peter et al., 1998).

In previous studies transgenic tobacco plants expressing functional different hemoglobins have been produced (Dyerick et al., 1997; Holmberg et al., 1997; Bulow et al., 1999). In the present work, targeting of heterologous $\mathrm{Lb}$ to tobacco chloroplasts was performed to determine whether $\mathrm{Lb}$ can be correctly imported and processed inside the organelle and to examine the effects on photosynthesis, carbohydrates, chlorophyll and the activities of enzymes involved in oxidative stress. It has been demonstrated that the presence of $\mathrm{Lb}$ in chloroplasts does not interfere with aerobic metabolism in transgenic plants. This may be due to the presence of insufficient quantities of $\mathrm{Lb}$ to alter the rate of diffusion of the high concentrations of oxygen found inside the chloroplast. 


\section{Material and methods}

\section{Gene constructions}

Standard procedures were used for DNA manipulations (Sambrook et al.,. 1989). The constructs assembling the Rubisco transit peptide and Lb were made as follows.

The prbcS plasmid carries a DNA fragment corresponding to the 5'-noncoding region, and the full-length cDNA of the small subunit precursor of Rubisco from pea (kindly provided by Dr. Kenton Ko, Queen's University, Canada). Using the polymerase chain reaction specific restriction sites were add to the flanking regions of the transit peptide encoding region. Synthetic primers provided with HindIII and EcoRI sites were as follows. The $r b c S 1$ upstream primer was $5^{\prime}-$

CCCAAGCCTTTAACAATGGCTTCC, and the $r b c S 2$ downstream primer was 5'CCCCGATTCCTGCATGCATTGCAG.

After polymerase chain reaction amplification, the fragment was digested with HindIII and EcoRI and inserted into the corresponding sites of SK(+) Bluescript (Stratagene), resulting in the $\mathrm{SK}(+) r b c S$ plasmid.

The leghemoglobin $a$ encoding sequence from soybean (kindly provided by Dr. K. Marcher, Aarhus University, Denmark) was modified at the flanking regions by the polymerase chain reaction. Synthetic primers provided with EcoRI and BamHI cloning sites were as follows. The legl upstream primer was 5'CCCGAAATTCAGAAATATGGTTGC, and the leg 2 downstream primer was 5'CCCGGATCCTACTAATTATGCC. 
After polymerase chain reaction amplification, the fragments were double digested respectly with EcoRI and BamHI and cloned in the corresponding sites of SK(+)rbcS (Stratagene), previously digested with EcoRI and Bam HI, resulting in the SK $(+) r b c S-L b$ plasmid. The authenticity of this construct was verified by DNA sequencing.

To prepare the rbcS-Lb construct for tobacco transformation, the Bin2-35ScatE9' (Silva-Filho et al., 1996) was digested with HindIII and treated with Klenow DNA polymerase so that the end was filled in. Immediately after, the plasmid was digested with Bam HI to release the chloramphenicol acetyltransferase encoding sequence. In parallel, the SK(+)rbcS-Lb plasmid was digested with HindIII, filled in with Klenow DNA polymerase and further digested with $B a m \mathrm{HI}$, releasing the chimeric gene $r b c S-L b$. This fragment was inserted into the corresponding sites of the modified Bin2-35ScatE9' vector, producing the plant transformation vector Bin2-35SrbcS-LbE9'.

To prepare the plant transformation Bin2-35SLbE9' without the targeting sequence, the plasmid SK(+)rbcS-Lb was digested with EcoRI and BamHI, releasing the $L b$ gene. This fragment was then inserted into the corresponding sites of Bin2-35ScatE9' vector previously digested with EcoRI and Bam HI.

\section{Plant transformation}

Transformation experiments were performed with Nicotiana tabacum as previously described (Bevan, 1984; Chaumont et al., 1994). Regenerated plants were selected for kanamycin resistance. 


\section{Plant material and growth conditions}

Seeds of SRI Petite Havana $N$. tabacum lines were sown in a commercial substrate and fed with commercial fertiliser at least twice a week. Plants were grown in a glasshouse under a photoperiod of $14 / 10 \mathrm{~h}$ day/night and a temperature of $20 / 35^{\circ} \mathrm{C}$. For metabolite extraction analyses, leaf discs (approx. $10 \mathrm{~cm}^{2}$ ) from control and four independent $\mathrm{S}_{2}$ transformants (R3, R6, R9, and R10) were harvested from fully expanded leaves (third or fourth from the apex).

\section{Chlorophyll assay}

Leaf samples from four-week old plants were homogenized in $1.5 \mathrm{ml}$ tubes and the chlorophyll was extracted with ice-cold $80 \%$ buffered acetone. The debris was removed and the supernatants were collected. The absorbance of the chlorophyll extracts were monitored at 663 and $646 \mathrm{~nm}$. The amounts of chlorophyll- $a$ and $b$ were calculated as described (Wellburn, 1994).

\section{Metabolite measurements}

Sucrose contents were extracted from leaf discs according to the method of Leegood and Furbank (1986) and determined as described previously (Lowry and Passoneau, 1972). For estimations of starch, the samples were assayed essentially as described by Jones et al. (1977). 
Catalase and glutathione reductase activities

Enzyme extraction was carried out as described previously by Azevedo et al. (1998). Catalase activity was determined as described by Kraus et al. (1995) with some modifications (Azevedo et al., 1998).

Glutathione reductase activity was determined according to Smith et al. (1988) with some modifications (Azevedo et al., 1998).

Protein quantitation

Protein concentration was determined spectrophotometrically at $595 \mathrm{~nm}$ as described by Bradford (1976) using the Bio-Rad Protein Assay Dye Reagent with bovine serum albumin as a standard.

Fractionation of tobacco cells and protein analysis

Subcellular fractions were obtained from $10 \mathrm{~g}$ of leaves as described previously (Chaumont et al., 1994) except that homogenisation was performed in $100 \mathrm{ml}$ of homogenisation buffer and that $0,2 \%(\mathrm{w} / \mathrm{v})$ insoluble polyvinylpyrrolidone was added to the buffer.

Purification of chloroplasts and thylakoids on a continuous Percoll gradient was performed according to Bruce et al. (1994).

\section{Western blot analysis}

After SDS-polyacrylamide gel electrophoresis, proteins were transferred to a nitrocellulose membrane and immunodetected with anti-goat leghemoglobin antibodies 
raised against purified leghemoglobin (1/1.000), followed by an Anti-Mice IgG alkaline phosphatase conjugate, (Sigma Chemical Co.).

\section{Gas exchange measurements}

Net photosynthesis, stomatal conductance, transpiration and internal $\mathrm{CO}_{2}$ concentration were determined in fully expanded leaves of each line using a portable infra-red gas analyzer (CIRAS P/P systems, Hitchin, UK). Photosynthetic active radiation (PAR) was approximately $600 \mu \mathrm{mol} \mathrm{m}^{-2} \mathrm{~s}^{-1}$ at leaf level. The air supply unit of the system was connected to two cylinders, one with $21 \% \mathrm{O}_{2}$ concentration and another with $1 \% \mathrm{O}_{2}$ concentration. Gas exchange parameters were first measured at ambient oxygen concentration $\left(21 \% \mathrm{O}_{2}\right)$. The air supply was then changed to $1 \% \mathrm{O}_{2}$ by a manual valve, and gas exchange parameters recorded once they had stabilised under nonphotorespiratory conditions (approximately $2 \mathrm{~min}$. after the switch between the two $\mathrm{O}_{2}$ concentrations). The effects of Line, oxygen concentration and their interaction were analysed by factorial analysis of variance (ANOVA) using SPSS (version 6.1.4) software. 


\section{Results}

The rbcS-transit peptide targets the soybean leghemoglobin into chloroplasts

The Rubisco transit peptide (rbcS) has been used successfully to introduce foreign proteins in vivo into chloroplasts (Van den Broeck et al., 1985, Boutry et al., 1987; Wan et al., 1996). In the present work, a gene construct was prepared to express the soybean leghemoglobin (Lb) into tobacco chloroplasts (Fig.1). The Rubisco transit peptide was fused to the soybean leghemoglobin $a$ (Hyldig-Nielson et al., 1982). The construct (rbcS-Lb) retained the whole rbcS targeting sequence, followed by four amino acid residues of the mature protein to allow cleavage of the transit peptide which might have required the surrounding residues. As a control, Lb was prepared without the targeting sequence assuring expression in the cytosol. Both chimaeric genes were placed under the control of the $35 \mathrm{~S}$ transcription promoter of cauliflower mosaic virus and the 3'-nonconding region of a pea Rubisco small subunit gene (Silva-Filho et al., 1997). These genes were introduced into tobacco, using an $A$. tumefaciens $\mathrm{T}_{\mathrm{i}}$ plasmid-derived vector. Transgenic plants were selfed and several independent $S_{2}$ plants were characterized for both constructs.

The level of $\mathrm{Lb}$ expression using the $35 \mathrm{~S}$ promoter was $0.01-0.1 \%$ of total soluble proteins for rbcS-Lb plants (data not shown). Similar results were also observed with the expression of human hemoglobin in tobacco seeds driven by the $35 \mathrm{~S}$ promoter (Dyerick et al., 1997).

Subcellular fractionation of the leaves was performed by centrifugation to obtain a crude cytosolic supernatant and a crude organellar pellet. Chloroplast-enriched 
fractions were obtained by differential centrifugation and subsequent purification of the organelles on Percoll gradients. In order to verify the subcellular location of $\mathrm{Lb}, \mathrm{a}$ chloroplast enriched fraction and a total homogenate were subjected to immunodetection. Western blot analysis of transgenic rbcS-Lb plants showed that leghemoglobin was targeted and correctly processed inside the chloroplasts (Fig. 2). Lb enrichment in the chloroplast fraction was low, but this was to be expected since chloroplast proteins of mesophyll cells represent up to $50 \%$ of the total proteins of the leaves (Silva-Filho et al., 1997). In plants carrying the 35S-Lb construct, Lb was found in the supernatant (cytosol) only, and no Lb was detected in the chloroplast fraction. As " expected, the size of the mature $\mathrm{Lb}$ observed for $\mathrm{rbcS}-\mathrm{Lb}$ in the chloroplast fraction was larger than that of the cytosolic Lb. This difference can be accounted by the presence of 4 amino acid residues of mature Rubisco and 1 residue from the linker region.

\section{Effect of chloroplast-leghemoglobin on metabolite levels}

Sucrose and starch are the major metabolites produced during the photosynthetic process. To determine the effects of the presence of soybean leghemoglobin inside the chloroplasts on carbohydrate levels, leaf samples were harvested from the control (WT) and four independent $F_{2}$ transformants and assayed for their sucrose (Fig. 3A) and starch (Fig. 3B) contents. The results indicate that the concentration of sucrose and starch are not affected, suggesting that primary carbon metabolism is not altered by the presence of $\mathrm{Lb}$ inside the organelle. Consistent with this, was the observation that plant growth and dry weight measurements were not statistically different (data not shown). In contrast, expression of a bacterial hemoglobin in the cytosol of transgenic tobacco promoted a 
significant increase in plant growth (Holmberg et al., 1997). These authors also showed an increase in chlorophyll- $b$ levels related to the untransformed plants and argued that the bacterial hemoglobin could supply oxygen for chlorophyll biosynthesis. To verify whether Lb could alter chlorophyll biosynthesis, the chlorophyll- $a$ and $b$ concentrations in the leaves of the transgenic and control plants were analised. As observed in Fig. 3C, there was no modification of chlorophyll contents in any of the transformed rbcS-Lb and 35S-Lb plants (data not shown).

\section{Catalase and glutathione reductase activities in transgenic plants}

During photorespiration, $\mathrm{H}_{2} \mathrm{O}_{2}$ is produced in the peroxisome by oxidation of glycolate and then rapidly removed by catalase (CAT, EC 1.11.1.6) inside the organelle. The relation of catalase activity and photorespiration has been well characterized (Lea and Blackwell, 1990; Zelitch, 1992; Brisson et al., 1998). Therefore, catalase activity was measured as an indicator of photorespiration in transgenic tobacco plants. At high light intensities, there is often an excess of PSI reduction and $\mathrm{NADP}^{+}$pools become fully reduced. Under these conditions, $\mathrm{O}_{2}$ accepts for electrons from PSI, leading to the generation of superoxide radicals through the Mehler reaction. This superoxide radical is then rapidly disproportionated to $\mathrm{H}_{2} \mathrm{O}_{2}$ by superoxide dismutase (SOD, EC 1.15.1.1), which may be associated with the thylakoids or in the stroma. The $\mathrm{H}_{2} \mathrm{O}_{2}$ produced is quickly scavenged via the ascorbate/glutathione pathway (Asada, 1994). Regeneration of these compounds is carried out by glutathione reductase (GR, EC 1.6.4.2). Therefore, CAT and GR activities have been investigated in transgenic and wild type plants. It was 
demonstrated that both enzyme activities were not affected by the presence of the leghemoglobin inside the chloroplasts (Fig. 4).

Gas exchange

Decreased $\mathrm{O}_{2}$ concentration significantly increased net photosynthesis $(\mathrm{P}<0.001)$ with increases in the range $30-35 \%$ respect to $21 \% \mathrm{O}_{2}$. There were no significant differences in net photosynthesis between lines at either $\mathrm{O}_{2}$ concentration. The Line $\mathrm{x}$ concentration interaction was also not significant for net photosynthesis or any other measured parameter (Table 1). Significant differences between lines and between $\mathrm{O}_{2}$ concentrations were observed for stomatal conductance and internal $\mathrm{CO}_{2}$ concentration (Table 1). Increases in stomatal conductance were approximately $8-12 \%$ at $1 \% \mathrm{O}_{2}$ for all lines; the wild type and R10 were also significantly different from the other 2 lines at both $\mathrm{O}_{2}$ concentration. At $1 \% \mathrm{O}_{2}$, internal $\mathrm{CO}_{2}$ concentration decreased (8-10\%) in all lines. No significant differences were observed for transpiration in any line or between $\mathrm{O}_{2}$ concentration (Table 1). 


\section{Discussion}

Enhanced plant growth and yield by the manipulation of the photosynthetic process has been a major goal of plant physiologists. As approximately $90 \%$ of the plant dry weight is derived from $\mathrm{CO}_{2}$ assimilated by photosynthesis, increasing the carboxylation reaction of Rubisco may be a great benefit to plant produtivity (Zelitch, 1992). Using molecular biology techniques, the soybean leghemoglobin $a$ gene fused to a chloroplast targeting sequence has been introduced into the tobacco genome, in an attempt to alter the aerobic metabolism of the transgenic plants. Western blot analysis showed that the Lba was targeted to chloroplasts and the transit peptide was correctly processed. Interestingly, in order to develop an alternative source of human hemoglobin $\mathrm{Hb})$ in transgenic plants, translocation of the $\mathrm{Hb}$ into chloroplasts mediated by the same Rubisco targeting sequence has been attempted. However, $\mathrm{Hb}$ was only observed in tobacco seeds and roots (Dieryck, et al., 1997). Nevertheless, in the present work it has been shown that Lba accumulated in chloroplasts, at a concentration ranging from 0.01 $0.1 \%$ of the total extracted proteins.

It has been suggested that an efficient system of oxygen transport may alter the flux through several metabolic pathways in plant cells (Holmberg et al., 1997; Arredondo-Peter et al., 1998; Sowa et al., 1998). For example, during germination na increased oxygen concentration may enhance respiration and reduce the build up of toxic compounds released during fermentation (Hoffinan et al., 1993). On the other hand, high temperatures stimulate the oxygenation reaction of Rubisco, which is responsible for the wasteful photorespiratory process in $\mathrm{C}_{3}$ plants. Therefore, increasing the carboxylation reaction of Rubisco by a reduction of the $\mathrm{O}_{2}$ concentration inside the 
chloroplast, by the expression of $\mathrm{Lb}$ has been the major aim of this work. In addition, expression of $\mathrm{Lb}$ in the cytosol of transgenic tobacco was also attempted in order to promote higher growth, enhanced dry matter, chlorophyll content and faster germination, as observed previously by Holmberg et al. (1997). Contrary to these results, expression of $\mathrm{Lb}$ in the cytosol did not affect any of the parameters analysed (Figs $3 \mathrm{a}-\mathrm{c}$ ). This is unexpected since soybean $\mathrm{Lb}$ has a much higher affinity for oxygen than the bacterial hemoglobin.

It has always proved very difficult to obtain a direct measurement of photorespiration due to the reassimilation of $\mathrm{CO}_{2}$. However, a comparison of the rates of photosynthetic $\mathrm{CO}_{2}$ assimilation at atmosferic concentrations of $\mathrm{O}_{2}(21 \%)$ and at $1-2 \%$ $\mathrm{O}_{2}$, has been frequently used as an indirect measurement (Daí et al., 1993). It is clear from Table 1, that there were no significant differences between the rates of photosynthetic $\mathrm{CO}_{2}$ assimilation at the two $\mathrm{O}_{2}$ concentrations, between the wild type and any of the three transgenic rbcS-Lb plants. Interestingly, Couture et al. (1994) have demonstrated that a chloroplast $\mathrm{Hb}$ was located in the pyrenoid and the thylakoid region in Chlamydomonas eugametos. The role of the pyrenoid has been suggested as creating a microaerobic environment where the $\mathrm{CO}_{2}$ to $\mathrm{O}_{2}$ ratio is maintained at a high level, through the action of carbonic anhydrase, thus at the expense of the competing $\mathrm{O}_{2}$ (Moroney and Somanchi, 1999). In cyanobacteria, it has been proposed that $\mathrm{Hb}$ is involved in delivering $\mathrm{O}_{2}$ to cytochrome oxidase under microaerobic conditions (Thorsteinsson et al., 1999). What could account for the absence of any discernible effect in the transgenic rbcS-Lb plants? It may be argued that the soybean Lb is not in a functional state in order to interfere on oxygen binding kinetics. However the more 
complex, tetrameric human hemoglobin was functional in tobacco chloroplasts (Dyerick et al., 1997), and the observation that a chloroplast hemoglobin is naturally found in the unicellular green algae (Couture et al., 1994), strongly argue that the soybean Lb is in a functional form within the transformed plants. Similarly, the observations that functional plant Lb and Hbs have been expressed in E. coli (Duff et al., 1997; Jones et al., 1998), would also indicate that the chloroplast located $\mathrm{Lb}$ could be able to operate as an $\mathrm{O}_{2}$ carrier.

Chloroplasts are organelles with a high rate of oxygen flux during the day, as oxygen is able to act as a product as well as a substrate in several metabolic reactions. To function as an oxygen carrier and to create a microaerobic environment in root nodules, the $\mathrm{Lb}$ exceeds the oxygen concentration by 10,000 fold (Wittenberg and Wittenberg, 1990). It has been shown that in the transgenic rbcS-Lb plants, Lb expression varied from $0.01-0.1 \%$ of the total soluble protein. Then, it suggests that to act effectively, the Lb concentration inside the chloroplast should be several times higher, in order to create a gradient that removes oxygen faster than the rate of diffusion of free oxygen. Estimating a ratio of 1:30 for barley $\mathrm{Hb}$ when compared to myoglobin in muscle cells, Hill (1998) pointed out that it would require a free oxygen concentration of less than $1 \mu \mathrm{M}$, before $\mathrm{Hb}$ became effective in oxygen diffusion.

At $25^{\circ} \mathrm{C}$, the $\mathrm{O}_{2}$ concentration inside chloroplasts has been estimated at being between 275-300 $\mu \mathrm{M}$ (Robinson, 1988). At this concentration an extremely high levels of $\mathrm{Lb}$ would be required to alter the carboxylation efficiency of Rubisco and influence other oxygen-dependent metabolic pathways. This would support the observations for a lack of significant biochemical changes in the transgenic plants, despite the high affinity of the expressed leghemoglobin for oxygen. 
Table 1. Measurements of transpiration (E), stomatal conductance (gs), net photosynthesis (A) and internal $\mathrm{CO}_{2}$ concentration (ci) at two concentration (21 and $1 \%$ ) on the $8^{\text {th }}$ leaf of each plant line. Data are means of 20 plants \pm SE. The results of analysis of variance are shown: ns indicates no difference; * and *** indicate that effects are significant at $\mathrm{P}<0.05$ and $\mathrm{P}<0.001$, respectly.

\begin{tabular}{|c|c|c|c|c|c|}
\hline Type & $\begin{array}{l}\mathrm{O}_{2} \\
(\%)\end{array}$ & $\begin{array}{c}\mathrm{A} \\
\left(\mu \mathrm{mol} \mathrm{CO} \mathrm{Cm}^{-2 \mathrm{~s}-1}\right)\end{array}$ & $\begin{array}{c}\mathrm{Ci} \\
(\mu \mathrm{mol} \mathrm{CO} 2)\end{array}$ & $\begin{array}{c}\text { gs } \\
\left(\mathrm{mmol} \mathrm{m}^{-2 \mathrm{~s}-1}\right)\end{array}$ & $\begin{array}{c}\mathrm{E} \\
\left(\mathrm{mmol} \mathrm{H} \mathrm{Om}^{-2 \mathrm{~s}-1}\right)\end{array}$ \\
\hline Wild & 21 & $12.7 \pm 0.32$ & $241.8 \pm 3.2$ & $250.8 \pm 16.4$ & $3.03 \pm 0.12$ \\
\hline R3 & 21 & $12.2 \pm 0.52$ & $257.0 \pm 2.6$ & $284.4 \pm 13.4$ & $3.27 \pm 0.13$ \\
\hline R9 & 21 & $12.2 \pm 0.47$ & $252.6 \pm 5.1$ & $283.5 \pm 20.9$ & $3.24 \pm 0.17$ \\
\hline $\mathrm{R} 10$ & 21 & $11.5 \pm 0.44$ & $248.0 \pm$ & $249.2 \pm 18.2$ & $2.98 \pm 0.16$ \\
\hline Wild & 1 & $16.5 \pm 0.44$ & $216.9 \pm 5.3$ & $270.8 \pm 16.4$ & $3.14 \pm 0.15$ \\
\hline R3 & 1 & $16.4 \pm 0.60$ & $236.9 \pm 3.3$ & $322.6 \pm 17.9$ & $3.45 \pm 0.14$ \\
\hline R9 & 1 & $16.2 \pm 0.59$ & $229.1 \pm 6.9$ & $317.8 \pm 26.6$ & $3.41 \pm 0.20$ \\
\hline $\mathrm{R} 10$ & 1 & $15.5 \pm 0.59$ & $225.3 \pm 7.9$ & $276.7 \pm 23.6$ & $3.13 \pm 0.18$ \\
\hline \multicolumn{6}{|c|}{ ANOVA } \\
\hline \multicolumn{2}{|c|}{$\mathrm{O}_{2}$ Concentration } & $* * *$ & $* * *$ & $*$ & ns \\
\hline \multicolumn{2}{|c|}{ Intercation } & ns & ns & ns & ns \\
\hline
\end{tabular}




\section{Acknowledgements}

This work was supported by a grant from the Fundação de Amparo à Pesquisa do Estado de São Paulo, FAPESP (94/03561-0) and CNPq. R.M.B. was supported by a graduate felowship from FAPESP. A.C. and S.M.C. were supported by grants from CAPES and CNPq respectly. M.C.S.F and R.A.A. are research fellows of the CNPq. 


\section{References}

Appleby CA. 1992. The origin and functions of haemoglobin in plants. Science Progress 76, 365-398.

Arredondo-Peter R, Hargrove MS, Moran JF, Sarath G, Klucas RV. 1998. Plant hemoglobins. Plant Physiology 118, 1121-1125.

Asada K. 1994. Mechanisms for scavenging ractive molecules generated in chloroplasts under light stress. In: Baker NR, Bowyer JR, eds. Photoinhibition of photosynthesis: from molecular mechanisms to the field. Oxford: BIOS, 129-142.

Azevedo RA, Alas RM, Smith RJ, Lea PJ. 1998. Response of antioxidant enzymes to ozone fumigation in the leaves and roots of wild-type and a catalase-deficient mutant of barley. Physiologia Plantarum 104, 280-292.

Becana M, Klucas RV. 1992. Oxidation and reduction of leghemoglobin in root nodules of leguminous plants. Plant Physiology 98, 1217-1221.

Bergersen FJ. 1996. Delivery of $\mathrm{O}_{2}$ to bacterioids. Protoplasma 191, 9-20.

Bevan M. 1984. Binary Agrobacterium vectors for plant transformation. Nucleic Acids Research 12, 8711-8721.

Boutry M, Nagy F, Poulsen C, Aoyagi K, Chua N-H. 1987. Targeting of bacterial chloramphenicol acetyltransferase to mitochondria in transgenic plants. Nature 328 , $340-342$

Bradford MM. 1976. A rapid and sensitive method for the quantification of microgram quantities of protein utilizing the principle of protein-dye binding. Analytical Biochemistry 72, 248-254. 
Brisson LF, Zelitch I, Harvir EA. 1998. Manipulation of catalase levels produced altered photosynthesis in transgenic plants. Plant Physiology 116, 259-269.

Bruce BD, Perry S, Froehlich J, Keegstra K. 1994. In vitro import of proteins into chloroplasts. In Gelvin SB, Schilperoort RA, eds. Plant Molecular Biology Manual. Dordrecht: Kluwer Academic Publishers, 1-15.

Bulow L, Holmberg N, Lilius G, Bailey JE. 1999. The metabolic effets of native and transgenic hemoglobins on plants. Trends in Biotechnology 17, 21-24.

Chaumont F, Silva Filho MC, Thomas D, Leterme S, Boutry M. 1994. Truncated presequences of mitochondrial $F_{1}$ - ATPase $\beta$-subunit from Nicotiana plumbaginifolia transport CAT and GUS proteins into mitochondria of transgenic tobacco. Plant Molecular Biology 24, 631-641.

Couture M, Chamberland H, St-Pierre B, Lafontaine J, Guertin M. 1994. Nuclear genes encoding chloroplast hemoglobins in the unicellular green alga Chlamydomonas eugametos. Molecular and General Genetics 243, 185-197.

Daí Z, Ku MSB, Edwards GE. 1993. $\mathrm{C}_{4}$ photosynthesis: the $\mathrm{CO}_{2}$ concentrating mechanism and photorespiration. Plant Physiology 103, 83-90.

Dieryck W, Pagnier J, Poyart C, Maarden MC, Gruber V, Bournat P, Baudino S, Merot B. 1997. Human haemoglobin from transgenic tobacco. Nature 386, 29-30.

Duff SMG, Wittenberg JB, Hill RD. 1997. Expression purification, and properties of recombinant barley (Hordeum sp.) hemoglobin. The Journal of Biological Chemistry 272, 16746-16752. 
Hartman FC, Harpel MR. 1994. Structure, function, regulation, and assembly of Dribulose-1,5-biphosphate carboxylase/oxygenase. Annual Review of Biochemistry 63, 197-234.

Hill RD. 1998. What are hemoglobins doing in plants? Canadian Journal of Botany 76, 707-712.

Hoffman P, Walter G, Wiedenroth E-M, Peine G. 1993. How the cereal cope with oxygen defficiency. Photosynthetica 4, 495-513.

Holmberg N, Lilius G, Bailey JE, Bulow L. 1997. Transgenic tobacco expressing Vitreoscilla hemoglobin exhibits enhanced growth and altered metabolic production. Nature Biotechnology 15, 244-247.

\section{Hyldig-Nielson JJ, Jensen EO, Paludan K, Wilborg O, Garret R, Joergensen P,} Marcker KA. 1982. The primary structure of two leghemoglobin genes from soybean. Nucleic Acids Research 10, 689-701.

Jones DH, Badii R, Rossel FI, Lloyd E. 1998. Bacterial expression and spectroscopic characterisation of soybean leghaemoglobin a. Biochemical Journal 330, 983-998.

Jones MGK, Outlaw WH, Lowry OH. 1977. Procedure for the assay of sucrose in range $10^{-7}-10^{-14}$ moles. Plant Physiology 60, 379-383.

Kanevski I, Maliga P, Rhoades DF, Gutheridge S. 1999. Plastome engineering of ribulose-1,5-biphosphate carboxylase/oxygenase in tobacco to form a sunflower large subunit and tobacco small subunit hybrid. Plant Physiology 119, 133-141.

Keys AJ. 1999. Biochemistry of photorespiration and the consequences for plant performance. In: Bryant JA, Burrell MM, Kruger NJ, eds. Plant Carbohydrate Biochemistry. Oxford: BIOS, 147-62. 
Kraus TE, McKersie BD, Fletcher RA. 1995. Paclobutrazol-induced tolerance of wheat leaves to paraquat may involve increased antioxidant enzyme activity. Journal of Plant Physiology 145, 570-576.

Lea PJ, Blackwell RD. 1990. Genetic regulation of the photorespiratory pathway. In: Zelitch I, ed. Perspectives in biochemical and genetic regulation of photosynthesis. New York: Wiley-Liss, 301-318.

Leegood RC, Furbank RT. 1986. Stimulation of photosynthesis by $2 \%$ oxygen at low temperatures is restored by phosphate. Planta $168,84-93$.

Lowry OH, Passoneau JV. 1972. A flexible system of enzymatic anlysis. New York: Academic Press.

Moore BD, Cheng S-H, Rice J, Leeman JR. 1998. Sucrose cycling, Rubisco expression and prediction of photosynthetic acclimation to elevated atmospheric $\mathrm{CO}_{2}$. Plant Cell and Environment 21,905-916.

Moroney JV, Somanchi A. 1999. How do algae concentrate CO2 to increase the efficiency of photosynthetic carbon fixation? Plant Physiology 119, 9-16.

Robinson JM. 1988. Does $\mathrm{O}_{2}$ photoreduction occur within chloroplasts in vivo? Physiologia Plantarum 72, 666-680.

Sambrook J, Fritsch EF, Maniatis T. 1989. Molecular Cloning: A laboratory manual. New York: Cold Spring Harbor.

Silva-Filho MC, Chaumont F, Leterme S, Boutry M. 1996. Mitochondrial and chloroplast targeting sequences in tandem modify protein import specificity in plant organelles. Plant Molecular Biology 30, 769-780. 
Silva-Filho MC, Wieers MC, Flugge U-I, Chaumont F, Boutry M. 1997. Different in vitro and in vivo targeting properties of the transit peptide of a chloroplast envelope inner membrane protein. The Journal of Biological Chemistry 272, 15264-15269.

Smith IK, Vierh eller TL, Thorne CA. 1988. Assay of glutathione reductase in crude tissue homogenates using 5,5'-dithiobis (2-nitrobenzoic acid). Analytical Biochemistry 175, 408-413.

Sowa AW, Duff SMG, Guy PA, Hill RD. 1998. Altering hemoglobin levels changes energy status in maize cells under hypoxia. Proceedings of the National Academy of Sciences, USA 95, 10317-10321.

Stitt M. 1996. Metabolic regulation of photosynthesis. In: Baker NR, eds. Photosynthesis and the Environment. Dordrecht: Kluwer, 151-90.

Thorsteinsson MV, Bevan DR, Potts M, Dou Y, Eich RF, Hargrove MS, Gibson QH, Olson JS. 1999. A cyanobacterial hemoglobin with unusual ligand binding kinetics and stability properties. Biochemistry $38,2117-2126$.

Van de Broeck G, Timko MP, Kausch AP, Cashmore AR, Van Montagu M, Herrera-Estrela L. 1985. Targeting of a foreign protein to chloroplasts by fusion to the transit peptide from the small subunit of ribulose-1,5-biphosphate carboxylase. Nature, 358-363.

Von Wettstein D, Gough S, Kannangara CG. 1995. Chlorophyll biosynthesis. The Plant Cell 7, 1039-1057.

Wellburn AR. 1994. The spectral determination of chlorophyll-A and chlorophyll-B, as well as total carotenoids, using various solvents with spectrophotometers of different resolution. Journal of Plant Physiology 144, 307-331. 
Wan J, Blakeley SD, Dennis DT, Ko K. 1996. Transit peptides play a role in the preferential import to proteins into leucoplasts and chloroplasts. The Journal of Biological Chemistry 271, 31227-31233.

Wittenberg JB, Wittenberg BA. 1990. Mechanisms of cytoplasmic hemoglobin and myoglobin function. Annual Review Biophys. Biophys. Chem. 19, 217-241.

Zelitch I. 1992. Control of plant produtivity by regulation of photorespiration. BioScience 42, 510-516. 


\section{Legends of Figures}

Fig. 1: Chimeric rbcS-Lb gene construct. Below the scheme of the rbcS-Lb construct is shown the nucleotide and amino acid sequences from the Rubisco $(\mathrm{rbcS})$ transit peptide, the retained mature Rubisco, as well as the linker region upstream of the $\mathrm{Lb}$ initiation codon. Linker amino acid residues are in italics. The HindIII restriction site is underlined. The Rubisco and Lb initiation codons are in bold. The vertical arrowhead represents the clevage point between the Rubisco transit peptide and the mature protein. Drawing is not to scale.

Fig. 2: Immunodetection of $\mathrm{Lb}$ in subcellular fractions of transgenic tobacco plants. Homogenization and subcellular fractionation of $\mathrm{rbcS}-\mathrm{Lb}$ and $\mathrm{Lb}$ transgenic plants were carried out as described under "Material and methods". Western blot analysis was carried out on $10 \mu \mathrm{g}$ proteins of the homogenate $(\mathrm{H})$ and the chloroplast $(\mathrm{C})$ enriched fraction. A soybean $\mathrm{Lb}$ protein extract $(0.1 \mu \mathrm{g})$ was used as a control (lane 1). Molecular mass $(\mathrm{kDa})$ is indicated.

Fig. 3: The metabolite concentrations in transgenic and control tobacco leaf discs. Sucrose and starch accumulated in leaves over the early morning and the late afternoon period. The ten replicate measurements were taken from each of five different plant lines, and the results are shown as the mean sucrose and starch accumulation (expressed in $\mu \mathrm{mol}$ hexose equivalents $\mathrm{mg}^{-1} \mathrm{chl}$ ). c) The amount of 
chlorophyll- $a$ and $b$ in the transgenic lines and a wild-type control. Data represents mean values from ten individual plants of each line \pm SE.

Fig. 4: a) CAT (catalase) activity $\left(\mu \mathrm{mol} \mathrm{mg}^{-1}\right.$ protein $\min ^{-1}$ ) and b) GR (glutathione reductase) activity in leaves (third from the apex) of wild type and transgenic plants (R3, R6, R9, and R10) after growth for 8 weeks in a glass-house (14/10 h day/night). Data represents means of 10 measurements \pm SE. 


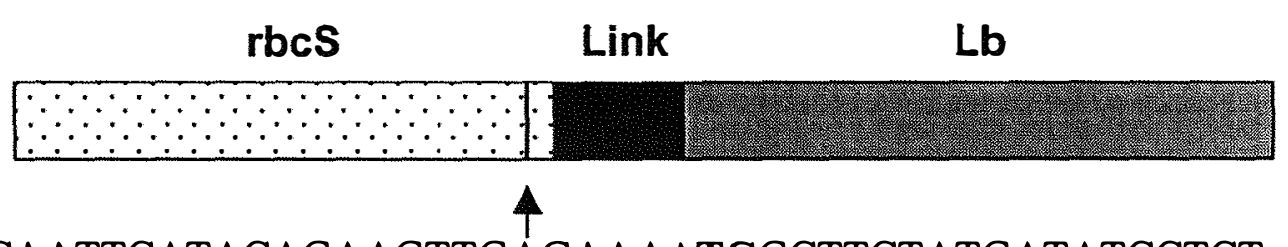

AAGCTTTGCAATTCATACAGAAGTTGAGAAAATGGCTTCTATGATATCCTCT

$\begin{array}{lllllll}M & \text { A } & \text { S } & \text { M } & \text { I } & \text { S } & \text { S }\end{array}$

TCCGCTGTGACAACAGTCAGCCGTGCCTCTAGGGGGCAATCCGCCGCAGTG

$\begin{array}{llllllllllllllllll}S & A & V & T & T & V & \text { S } & R & A & \text { S } & R & G & N & S & A & A & V\end{array}$ GCTCCATTCGGCGGCCTCAAATCCATGACTGGATTCCCAGTGAAGAAGGTC $\begin{array}{lllllllllllllllll}\text { A } & P & \text { F } & G & G & \text { L } & \text { K } & \text { S } & \text { M } & \text { T } & G & \text { F } & \text { P } & \text { V } & \text { K } & \text { K } & \text { V }\end{array}$ AACACTGACATTACTTCCATTACAAGCAATGGTGGAAGAGTAAAGTGCATG $\begin{array}{lllllllllllllllll}Q & \mathrm{~T} & \mathrm{E} & \mathrm{I} & \mathrm{T} & \mathrm{S} & \mathrm{I} & \mathrm{T} & \mathrm{S} & \mathrm{Q} & \mathrm{G} & \mathrm{G} & \mathrm{R} & \mathrm{V} & \mathrm{K} & \mathrm{C} & \mathrm{M}\end{array}$ GATCAATTCAGAAATATG

$\begin{array}{llllll}D & Q & F & R & N & \mathbf{M}\end{array}$ 


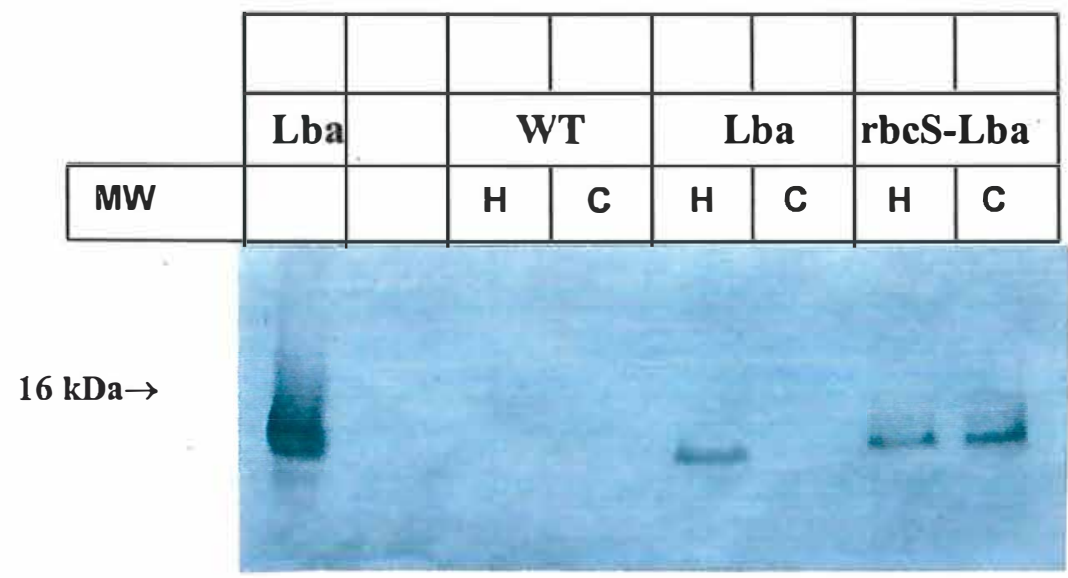


A)

B)
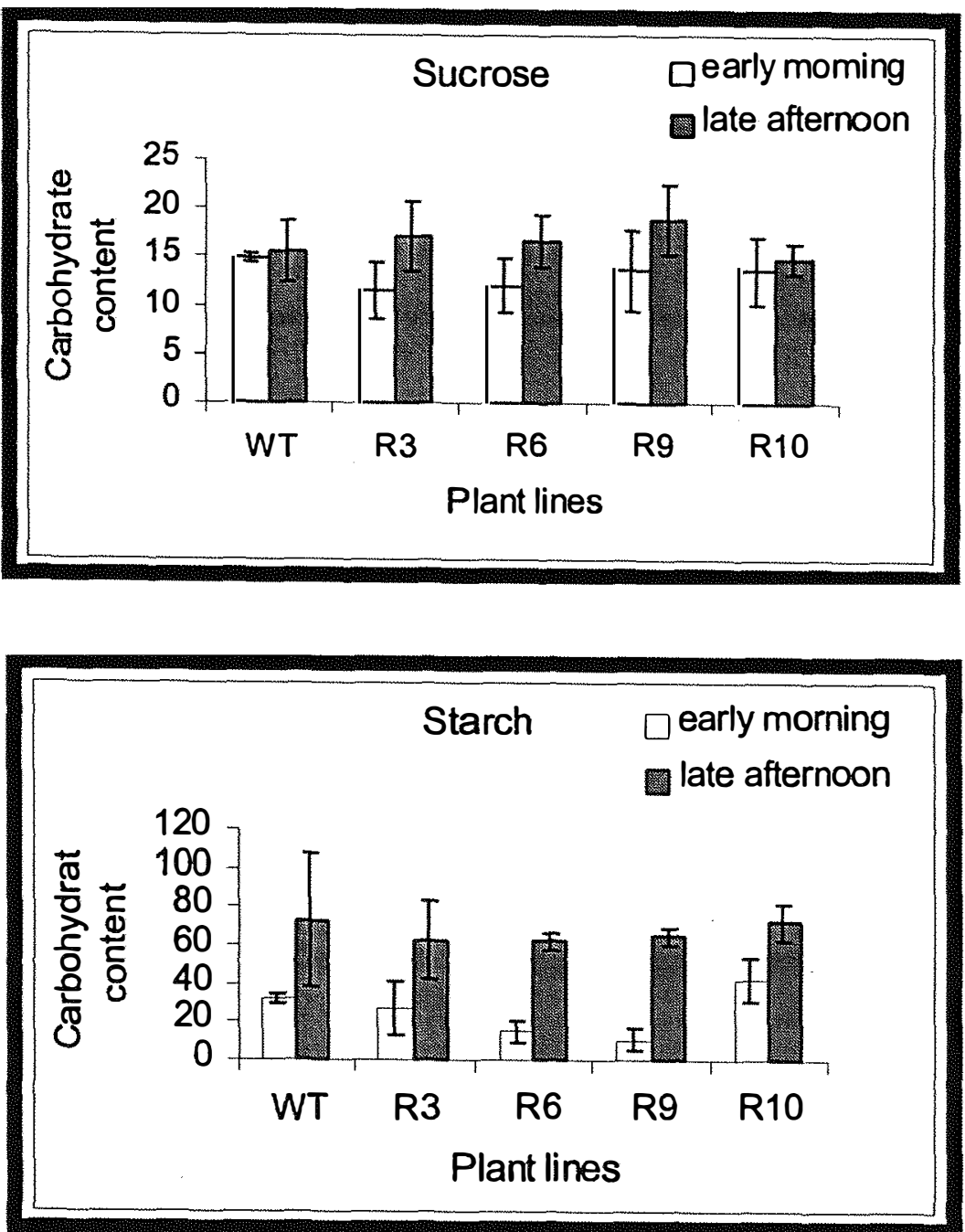

C)

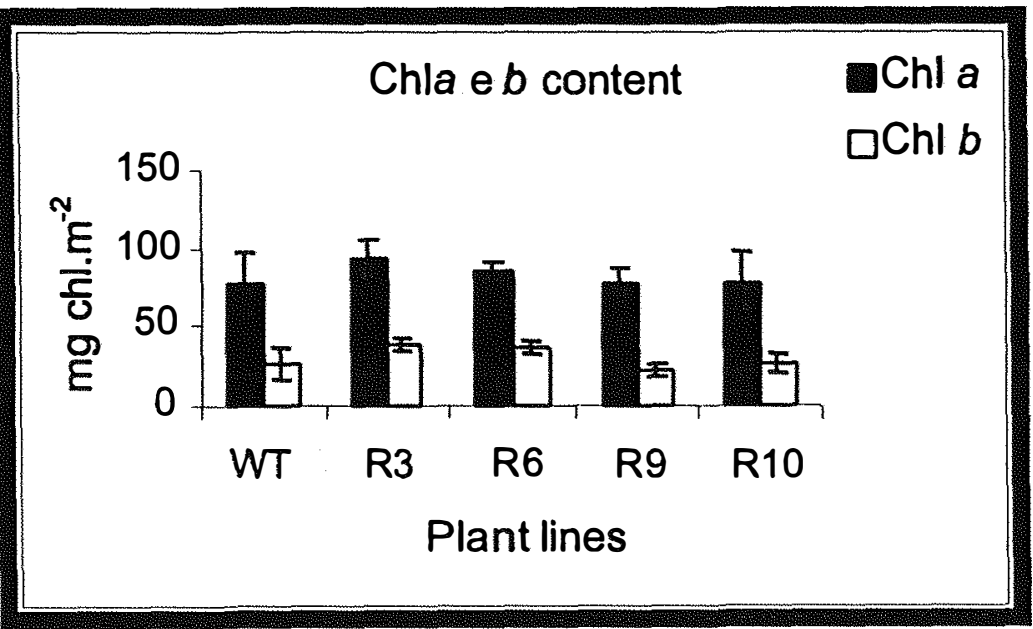


A)

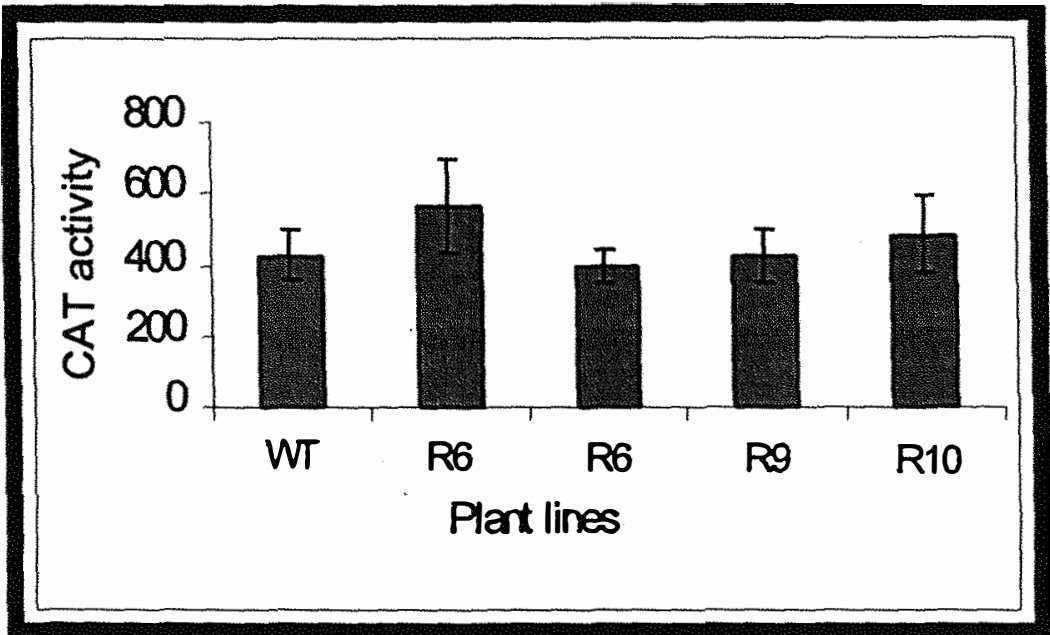

B)

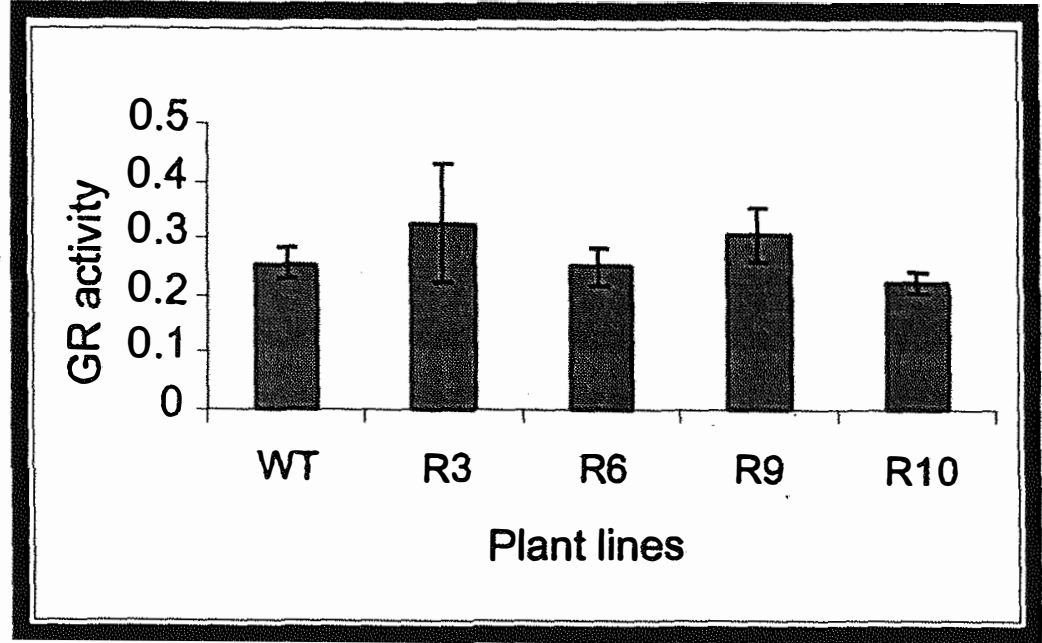

